
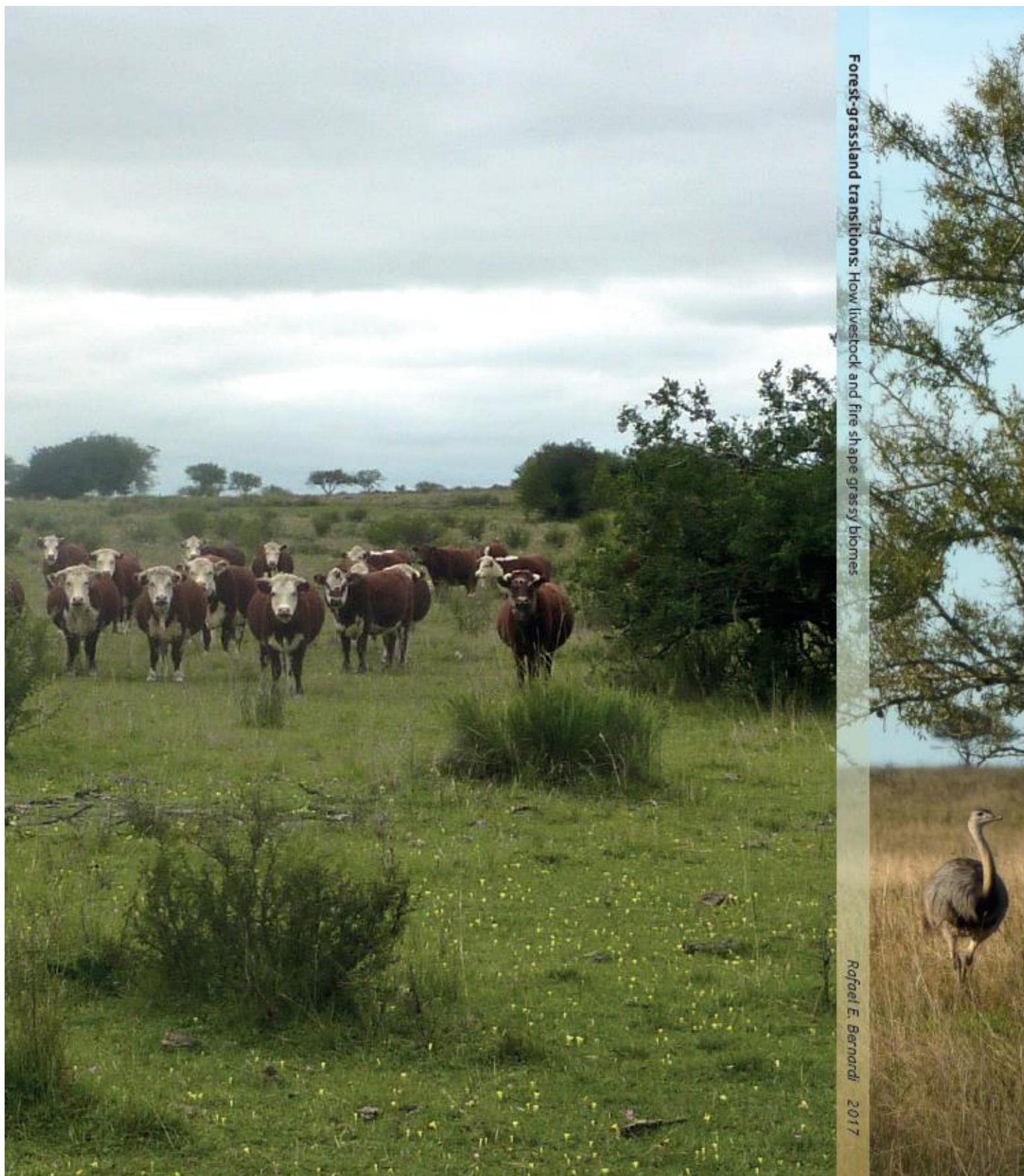

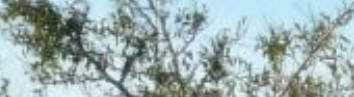

(6) $15 \times 1,2$

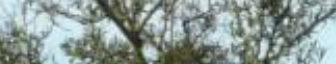

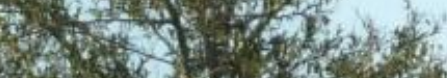

(x)

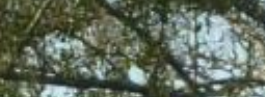

$7 \times$

\%.

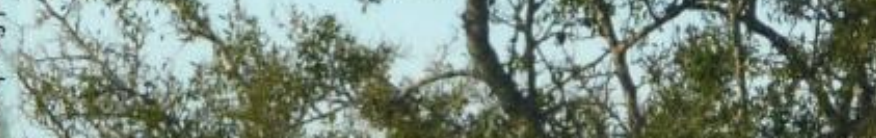

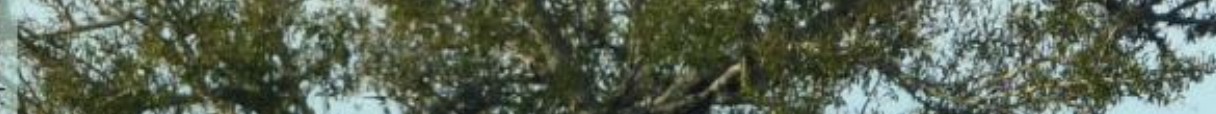

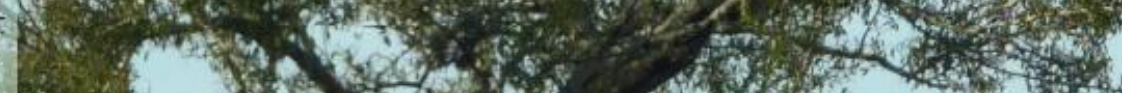
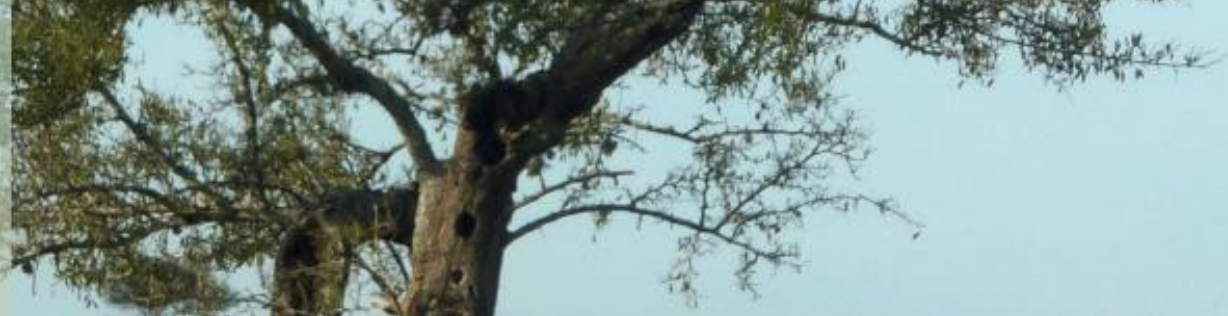

(x)

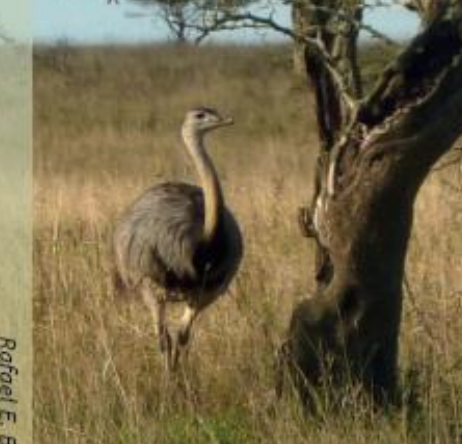

Forest-grassland transitions: How livestock and fire shape grassy biomes 


\section{Propositions}

1. Livestock limits fire frequency and shapes tree cover across the global tropics and subtropics. (this thesis)

2. In the subtropical grasslands of Uruguay, sparse trees improve forage quality and abundance. (this thesis)

3. If the millennia of human impact were considered, societies would develop a different appreciation of their environment.

4. The contribution of science to policy making is often limited by the scientist' ability to understand the needs of the participants in the political process.

5. A positive feedback between increasing inequality and the deterioration of democracy can result in regime shifts in political and economic systems.

6. A philosophy in which humans are one with nature is necessary to build sustainable societies.

Propositions belonging to the thesis, entitled

\section{"Forest-grassland transitions:}

How livestock and fire shape grassy biomes"

Rafael E. Bernardi

Wageningen, 15 November 2017 
Forest-grassland transitions:

How livestock and fire shape grassy biomes

Rafael E. Bernardi 


\section{Thesis committee}

\section{Promotor}

Prof. Dr Marten Scheffer

Professor of Aquatic Ecology and Water Quality Management

Wageningen University \& Research

\section{Co-promotors}

Dr Milena Holmgren

Associate professor, Resource Ecology Group

Wageningen University \& Research

Dr Matías Arim

Associate professor, Centro Universitario Regional del Este

Universidad de la República, Uruguay

\section{Other members}

Prof. Dr F.J.J.M. Bongers, Wageningen University \& Research

Prof. Dr B. Muys, KU Leuven, Belgium

Prof. Dr M.G. Rietkerk, Utrecht University

Dr C.G. van Reenen, Wageningen University \& Research

This research was conducted under the auspices of the Graduate School of SocioEconomic and Natural Sciences of the Environment (SENSE), The Netherlands. 


\title{
Forest-grassland transitions:
}

\section{How livestock and fire shape grassy biomes}

\author{
Rafael E. Bernardi
}

\section{Thesis}

submitted in fulfillment of the requirements for the degree of doctor at Wageningen University

by the authority of the Rector Magnificus,

Prof. Dr A.P.J. Mol, in the presence of the

Thesis Committee appointed by the Academic Board

to be defended in public

on Wednesday 15 November 2017

at 11 a.m. in the Aula. 
Rafael E. Bernardi

Forest-grassland transitions: How livestock and fire shape grassy biomes, 129 pages.

$\mathrm{PhD}$ thesis, Wageningen University, Wageningen, the Netherlands (2017) With references, with summaries in English and Spanish

ISBN: 978-94-6343-621-2

DOI: $10.18174 / 419101$ 
Table of contents

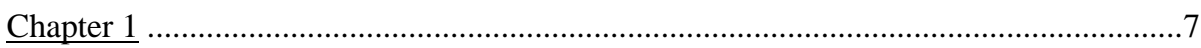

\section{General introduction}

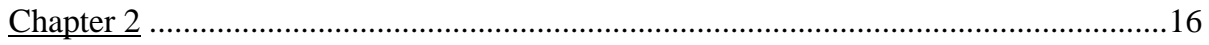

Why are forests so scarce in subtropical South America?

The shaping roles of climate, fire and livestock

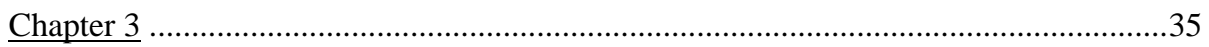

Land use drives forest-grassland transitions in subtropical South America

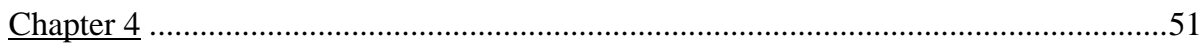

Trees improve forage quality and abundance in South American subtropical grasslands

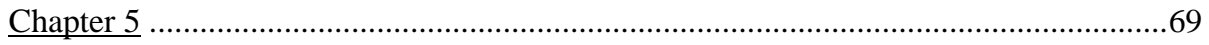

Livestock suppresses fire across the global tropics

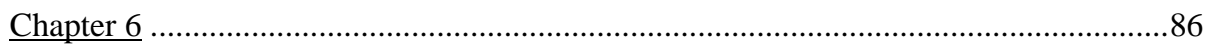

Synthesis

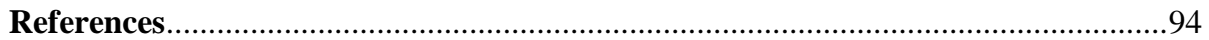

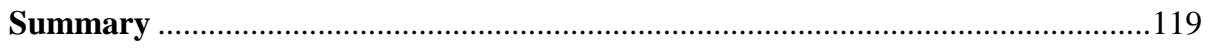

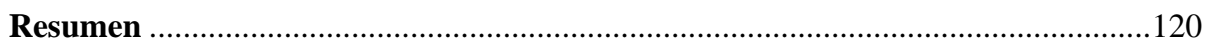

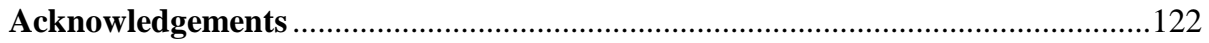

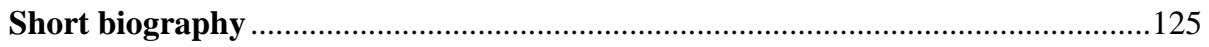

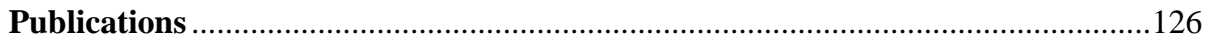

WIMEK-SENSE Training and Education Statement ……………………….......127 


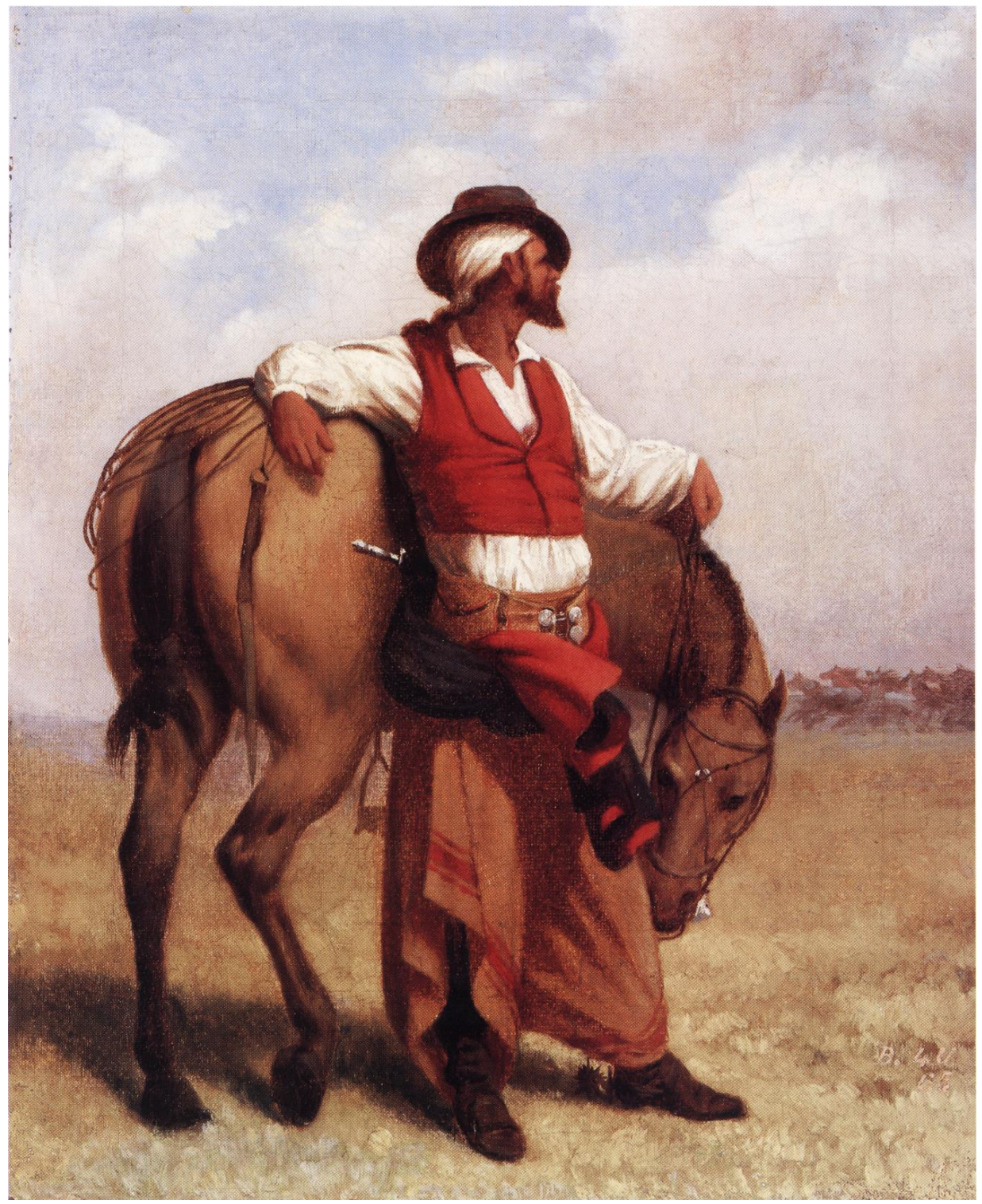

Juan Manuel Blanes. El Capataz. 1865 


\section{Chapter 1}

\section{General Introduction}

In the last few thousand years, humans have become the most significant factor in modifying planetary conditions, and their effects on ecosystems are widespread, even in areas previously considered pristine (Pandolfi et al. 2003, Steffen et al. 2007, Barlow et al. 2012). Terrestrial ecosystems across the planet are being shaped by climate change and human activities, which can fundamentally alter composition and structure of plant associations (Chapin III et al. 2000, Pearson and Dawson 2003, Walther 2010). Preventing or managing these changes and their consequences in terms of ecosystem services (Foley et al. 2005, MEA 2005) requires understanding how ecosystems are affected by environmental conditions and how resilient they are to external changes (Chapin III et al. 2009, Scheffer et al. 2015). However, in many ecosystems, these questions are far from answered.

\section{Determinants of tree cover}

The distribution of forests, savannas and grasslands has been studied since the first observations by early ecologists that related ecosystem structure to local environmental conditions (Von Humboldt and Bonpland 1807, Darwin 1890). The key role of climate for the distribution of terrestrial biomes, and particularly, the strong correlation between tree cover and annual rainfall, has long been established (Whittaker 1970, Woodward et al. 2004, Sankaran et al. 2005). Climate conditions are generally accepted as a main determinant of the dominant plant ecosystems, conditioning plant interactions, dispersal 
processes and evolutionary trajectories (Pearson and Dawson 2003). In the tropics, regions above $\sim 2000 \mathrm{~mm}$ of mean annual rainfall are mostly occupied by rainforests, which are characterized by a closed tree canopy that prevents the formation of a grassy understory (Whittaker 1970, Bucini and Hanan 2007, Hirota et al. 2011, Ratnam et al. 2011, Staver et al. 2011). As precipitation decreases, tree cover becomes sparser, and savannas and grasslands become dominant (Whittaker 1970, Bond and Parr 2010, Lehmann et al. 2011, Parr et al. 2014, Veldman et al. 2015). Grasslands and savannas can be defined by having a prevalence of grasses, mostly belonging to the Poaceae family, and absence or low cover of woody vegetation. In general, these grassy biomes develop under arid conditions, and often have high disturbance regimes of fire and herbivory (Gibson 2009). The view of climate determinants as the main explanation for ecosystem distribution has been widely accepted throughout the last century.

However, large regions of the world show a discrepancy between their tree cover and that predicted by climatic conditions (Bond 2005). This is particularly outstanding in large grasslands in subtropical South America, where tree cover is sparser that what would be expected from its precipitation regimes. This was first observed by Darwin in the Voyage of the Beagle, who noted the "remarkable" and "almost entire" absence of trees in Uruguay, despite the occurrence of enough precipitation (Darwin 1890). Understanding the factors explaining tree cover has since then been a puzzling question with highly significant ecological, social and economic consequences.

Explaining tree cover distribution requires taking into account the interplay of resource availability, mostly determined by climate and soil features, the occurrence of disturbances, such as herbivory and fire, and the local landscape features that can mediate the effect of both. Indeed, interacting with regional climatic conditions, soils can also influence tree cover. Edaphic properties such as organic matter, nutrient content and water 
retention capacity can determine access to resources affecting tree establishment and growth, thus modifying the relationship between trees and grasses (House et al. 2003, Lehmann et al. 2011, Mills et al. 2013). Resource availability has been found to influence the interplay of facilitation or competition between trees and grasses at the early stages of tree development, thus affecting tree cover (Scholes and Archer 1997, Callaway 2007, February et al. 2013).

Disturbances are also known to shape tree cover. Grassy biomes have adapted to a high frequency of disturbances, i.e. fire and herbivory (Gibson 2009). Fire has a wellknown effect of tree suppression in favor of grasses, and may be a key mechanism explaining the perceived lack of linear response of tree cover to increases in rainfall. Indeed, recent studies of multi-modalities in the frequency distribution of tree cover and height suggest that forests, savannas and grasslands may be alternative states of tree cover over the same wide range of precipitation (ca. between 1000-2000 mm year-1) (Hirota et al. 2011, Staver et al. 2011, Xu et al. 2016). A positive feedback between fire and vegetation, that involves a cycle of rapid production of grass after the occurrence of a fire resulting in more fuel for future fires, has been suggested as a main mechanism controlling the distribution of tropical savannas (Sankaran et al. 2005, Archibald et al. 2009, Hirota et al. 2011, Staver et al. 2011, Hoffmann et al. 2012, Murphy and Bowman 2012). This process may thus explain the occurrence of savannas and mosaics of forests in grasslands across regions with enough precipitation to sustain forests (Sankaran et al. 2005, Blanco et al. 2014).

The grass-fire feedback interacts with the availability of resources, such as soil fertility, determined by landscape gradients which can plausibly affect the probability of transitions between states. However, there are several hypothesis on how disturbance and 
resource interactions determine tree cover and the matter is still under debate (Murphy and Bowman 2012, Quesada et al. 2012, Staal and Flores 2015, Dantas et al. 2016).

Disturbance by herbivory also plays a significant role in shaping vegetation community structure and taxonomic and functional composition through different mechanisms (Walter 1971, Prins and van der Jeugd 1993, Scholes and Archer 1997, Asner et al. 2004, Asner et al. 2009, Staver and Bond 2014). Herbivores can reduce woody cover by browsing and trampling on trees, particularly during the early growth stages (Huntly 1991, Griscom et al. 2005, Chaturvedi et al. 2012, Holmgren et al. 2012, Etchebarne and Brazeiro 2016). On the other hand, herbivores can promote tree expansion through seed dispersal (Walter 1971, Scholes and Archer 1997). By consuming grasses, herbivores can also affect fire regimes, altering the mechanisms that are thought to determine tree cover states (Archibald et al. 2005). By reducing grass biomass that serves as fuel for fire, grazers can disrupt the grass-fire feedback that prevents the growth of trees. These mechanisms could potentially facilitate woody encroachment into grasslands, a current global trend (Roques et al. 2001, Naito and Cairns 2011, Hoffmann et al. 2012).

Herbivory regimes have changed since livestock domestication by humans. Managed grazing is today the largest human land use, even more extensive than agriculture, spanning over one third of the global surface and over half of the world's savannas and grasslands (Asner et al. 2004). In many regions of the world, livestock has replaced wild fauna as the dominant herbivore, with significant effects on vegetation of grasslands and savannas (Belsky and Blumenthal 1997, Macias et al. 2014). Despite these potential effects, a systemic analysis of the overall effects of livestock on vegetation and fire dynamics on tropical and subtropical systems is lacking. Given the extent of livestock 
systems across the world, it may be a major force in shaping terrestrial biomes that has not been adequately considered so far.

This section presented an overview of the different determinants that can explain tree cover distribution and forest - grassland transitions. Together with these variables, explaining tree cover also requires addressing the scale at which the different variables operate. The scale-dependency of the ecological mechanisms is accepted but still poorly considered (Levin 1992). Intermediate scales are often neglected since most studies tend to focus on either large-scale analyses of ecosystem types or on small-scale experimental data. Specifically, this dissertation focuses on the factors explaining tree cover distribution at multiple spatial scales, including intermediate scales, aiming to capture the effects of variables that may otherwise be missed. It also considers temporal scales by analyzing forest-grassland transitions over several decades, to overcome any limitation that may result from using current tree cover distribution.

The potential for shifts between alternative tree cover states, together with trends of woody encroachment into grasslands are deemed problematic due to potential decreases in productivity of rangelands (Moleele et al. 2002, Van Auken 2009, Chaneton et al. 2012, Ratajczak et al. 2012, Anadón et al. 2014b, Stevens et al. 2017). To understand consequences of potential tree cover transitions, in the following section I look at the effects of trees on grasses, focusing on the production of forage for livestock, the main socio-economic use of grasslands in subtropical South America.

\section{Effects of trees in grasslands}

Trees in grasslands can impact ecosystem structure and function, with consequences on ecosystem services. Trees can locally change microclimate conditions, water availability, soil properties, and disturbance regimes known to affect grasslands assembly (Holmgren 
et al. 1997, Scholes and Archer 1997, Callaway 2007, Dohn et al. 2013). Woody expansion can progress to form dense or closed canopies that can suppress grasses by limiting light (Archibald et al. 2005, Bond 2016). This reduction in grass biomass can in turn impact livestock productivity, an often lead to significant problems in rangelands (Van Auken 2009, Eldridge et al. 2011). On the other hand, trees can facilitate the growth of herbaceous plants through various mechanisms including local cooling and reduced evaporation, increased underground water uptake by hydraulic lift (Ludwig et al. 2003, Neumann and Cardon 2012), symbiotic nitrogen fixation in the case of leguminous trees (Stacey et al. 1992), and changes in soil microbiota (Huxley 1999). Trees can also improve forage quality and abundance in rangelands, indirectly increasing nutrient content and growth of palatable species (Jackson et al. 1990, Jackson and Ash 1998, Treydte et al. 2007, Ludwig et al. 2008, Gea-Izquierdo et al. 2009, Peri et al. 2016). The availability of resources is thought to determine the nature of interactions between trees and grasses. In drier regions where resources are scarce, facilitation between trees and grasses may be more relevant than competition, but the nature of this interplay in subhumid environments is less understood (Callaway 2007, Holmgren and Scheffer 2010, Dohn et al. 2013).

In particular, little knowledge exists about the effect of trees in the grass layer in the mixed C3-C4 grasslands of subtropical South America. Extensive livestock is the main economic use of these old-growth grasslands (Veldman et al. 2015), and any impact on the capacity of these ecosystems to sustain livestock production may result in large socio-economic effects, with some analysis suggesting strong negative consequences (Anadón et al. 2014b). These concerns reinforce ranching and farming cultural views that regard trees as a nuisance for agricultural activities, with negative perceptions of the expansion of trees into grasslands (Holmgren and Scheffer 2017). Consequently, in this 
thesis I analyze the effect of trees in the abundance and quality of forage in the understory of rangelands, to better understand potential consequences of tree cover transitions.

\section{Thesis scope and study area}

The main hypothesis of this thesis is that disturbances play a major role in determining the distribution and transitions between forests, savannas and grasslands in the tropics and subtropics, and that livestock in particular has a significant role in shaping these ecosystems, by reducing fire frequency and limiting tree expansion into grasslands. I also hypothesize that trees can have positive local effects on the understory herbaceous layer, thus enhancing some of the ecosystem services of rangelands.

This dissertation focuses first on the extensive subtropical grasslands of southeastern South America, and the Uruguayan Savanna Ecoregion, locally known as "Campos" (Olson et al. 2001). These "old-grown" grasslands (Puerto et al. 2013, Veldman et al. 2015) extend across Uruguay and are an ecotone between tropical systems in Brazil and the temperate grasslands of Argentina, with high diversity of herbaceous and tree species (Overbeck et al. 2007, Haretche et al. 2012). We then expand our analysis to the global tropics and subtropics, aiming to generalize some of our results at the global scale.

\section{Thesis outline}

This thesis focuses on the factors that explain tree cover distribution in grasslands and savannas. With my co-authors, I combined correlational remote sensing and ground data of tree cover distribution at several spatial scales in subtropical South America, cartographic data of forest change along a 40 year period in the grasslands of Uruguay, 
and field data of tree-grass interactions to assess potential local consequences on forage for livestock. Finally, the scale of analysis was expanded to the global tropics and subtropics, looking for generalizations of main findings at the global scale. The thesis is organized in the following chapters:

Chapter 1 (this chapter) provides an introduction to the general concepts and state of the art on the issues addressed by this thesis.

In Chapter 2, I analyze the potential determinants of tree cover considering environmental conditions and land use regimes. Further, I explicitly considered the scale dependence of these associations. To this aim, I used remote-sensing and ground information together with spatial regression models to relate tree cover to resource availability (i.e. climate, soil fertility, soil water holding capacity), disturbance regimes (i.e. fire occurrence, cattle grazing) and landscape features (i.e. topography, distance to rivers). I analyzed this relationship for different scales in South America, i.e. the Campos of Uruguay and Brazil (Uruguayan Savanna Ecoregion), a larger region comprising the subtropical region in southeastern South America, and the whole southeastern South America with the same rainfall levels as the Campos region.

In Chapter 3, I focus on the observed change in forest cover during a 44-year period in the Campos of Uruguay. Using forest cartography combined with present and historical information, we modeled tree cover changes as a function of ecological and land use variables, attempting to explain transitions between grasslands and forests in the context of coupled socio-ecological systems (Liu et al. 2007).

In Chapter 4, I analyze the local interaction of trees and grasses, aiming to understand potential impacts of trees in the composition, abundance and nutritional quality of the grass layer under trees. To this aim, herbaceous composition, abundance 
and chemical contents under and outside isolated trees in 12 sites with different grazing intensity were sampled in the subtropical Campos rangelands of central Uruguay.

In Chapter 5, standing on previous results, I focus on fire frequency and its relationship with livestock at the largest scale. Specifically, I used remote sensing and ground data on fire frequency, woody height and cover, climate and livestock to analyze the effects of livestock on fire regimes, and the changes in vegetation associated to the density of livestock in the tropics and subtropics across continents. 


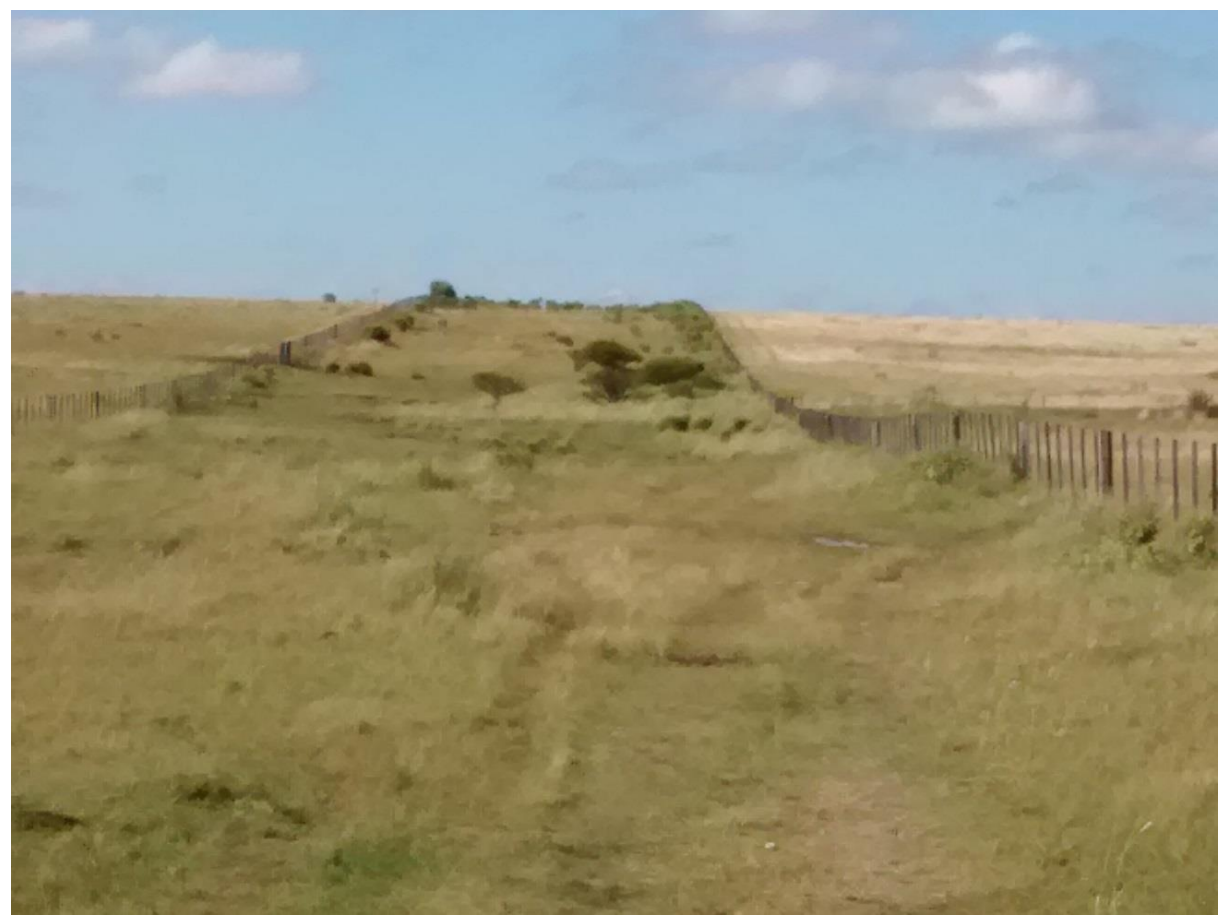

Photograph and artwork: Rafael Bernardi

\section{Chapter 2}

\section{Why are forests so scarce in subtropical South America?}

The shaping roles of climate, fire and livestock

Rafael E. Bernardi, Milena Holmgren, Matías Arim, Marten Scheffer

\section{Published in Forest Ecology and Management.}

Bernardi R.E., M. Holmgren, M. Arim, and M. Scheffer. 2016. Why are forests so scarce in subtropical South America? The shaping roles of climate, fire and livestock. Forest Ecology and Management 363:212-217. 


\begin{abstract}
Forest cover is notoriously sparse across neotropical Southeastern South America. In particular, the practically treeless landscapes of the Campos, as they are locally known, have puzzled ecologists since Darwin's time. We used remote-sensing information and spatial regression models to relate tree cover to resource availability (i.e. climate, soil fertility, soil water holding capacity), disturbances (i.e. fire occurrence, cattle grazing) and landscape features that can mediate the effects of both (i.e. topography, distance to rivers). To better understand these relationships, we conducted the analysis at different spatial scales across non-cultivated areas of southeastern South America. Overall, tree cover in southeastern South America increases with precipitation but is limited by livestock grazing and fire occurrence. Forests are concentrated close to rivers, especially in the Campos region, where cattle grazing seems to prevent tree expansion into the grasslands.
\end{abstract}

Keywords: Campos, cattle, rangelands, savanna, tropical tree cover, woody encroachment.

\title{
Introduction
}

The extensive grasslands of the Uruguayan Savanna Ecoregion, also known as Campos, represent a regional ecotone between the subtropical and tropical forests and the temperate grasslands of South America (Soriano 1992, Olson et al. 2001). These practically treeless landscapes have fascinated ecologists as far back as the 19th century. Darwin, during the voyage of the Beagle, noted the "general, almost entire", "remarkable" absence of trees in Uruguay despite the relatively high rainfall level (Darwin 1890). This strong correlation between increasing rainfall levels and higher tree cover has long been 
recognized (Whittaker 1970, Woodward et al. 2004, Sankaran et al. 2005). More recently, analyses at global scales have found an increasing probability in the occurrence of savannas and forests as mean annual precipitation increases (Hirota et al. 2011, Staver and Hansen 2015).

The treeless landscapes of southeastern South America are likely the combined result of past and current processes. It has been suggested that large areas of grasslands, in today's moister climate, may be relicts of drier periods (Pillar and Quadros 1997) that were common in the past 13,000 years (Piovano et al. 2009). Indeed, trees and shrubs have expanded locally across the region during the moister climate condition of the last century suggesting the potential for larger tree cover under the current moister climate (Gautreau 2010, Müller et al. 2012, Anadón et al. 2014a). Anthropogenic effects may also play an important role in explaining this process (Lauenroth 1979, Sala 2001, Lemaire et al. 2005), as suggested by the expansion of shrubs and trees in sites where fire or grazing have been excluded (Pillar and Quadros 1997, Oliveira and Pillar 2004, Overbeck et al. 2007, Chaneton et al. 2012, Müller et al. 2012, Cingolani et al. 2014, Lezama et al. 2014).

To understand the large scale patterns of tree cover across the Campos region, we analyzed the distribution of tree cover in relation to resources (i.e. climate, soil fertility, soil water holding capacity), disturbances (i.e. fire occurrence, cattle grazing) and landscape features (i.e. topography, distance to rivers). We compared the patterns of the Campos with those of subtropical and tropical regions in southeastern South American (SSA) within the same precipitation range than the Campos. These large scale analyses aim to unravel the common processes that contribute to shape the structure of distinct plant communities regardless of their differences in species composition. The climate of this region has become moister and warmer during the last century (Haylock et al. 2006), a trend that is expected to continue with climate warming (Marengo et al. 2010, Stocker 
et al. 2013) and that can favor tree growth. Understanding how climate and disturbance regimes interact today may contribute to anticipate potential changes in one of the world's most important rangelands.

\section{Materials and methods}

\section{Study regions}

We studied tree cover distribution in the Uruguayan Savanna ecoregion (NT0710) (Olson et al. 2001), formed by the entire Uruguay and southern Brazil (hereafter the Campos as it is locally known, Fig. 2.1). Mean annual precipitation in the Campos ranges between 1000 and 1900 mm (period 1961-2002; Climatic Research Unit database) (Jones and Harris 2013). We also analyzed the wider region within the same precipitation range than the Campos (1000-1900 mm), covering 1) the subtropical range delimited using the subtropical regions ( $\mathrm{Cf}$ and $\mathrm{Cw}$ ) in the original Köppen-Geiger classification, currently described as warm temperate, humid or winter-dry regions in updated classifications (Kottek et al. 2006, Peel et al. 2007); and 2) expanding the analysis following the 1000 and 1900 contours beyond the subtropics to include the tropical regions of southeastern South America (hereafter SSA) (14-38S and 62W-Atlantic Ocean, Fig. 2.1). Areas with precipitation outside the 1000-1900 mm range within both the subtropical and tropical ranges of southeastern South America were excluded from the analysis. These regions have the same precipitation range than the Campos but a wider variation in environmental conditions, enabling us to assess the potential interacting role of other drivers with precipitation. We did not include cultivated or urban areas where the original vegetation cover has been lost, therefore we did not assess forest conversion to cropland or urbanization, which are well-known primary causes of forest change. 


\section{Tree cover and environmental variables}

We related tree cover to environmental variables describing resource availability (climate, soil fertility), landscape features, and disturbance regimes (grazing and fire occurrence) (Table A.2.1). Tree cover was obtained from the Landsat vegetation continuous fields (VCF) with a 30-m resolution (Sexton et al. 2013). This dataset is particularly suitable for areas with sparse vegetation (Hansen et al. 2003, Hansen et al. 2005, Sexton et al. 2013, Staver and Hansen 2015). We also used the tree cover dataset from the Modis Mod44b VCF Collection 5 with a resolution of $250 \mathrm{~m}$ (DiMiceli et al. 2011), using the quality assurance layer to exclude those pixels with low quality on two or more input surface reflectance files (Townshend et al. 2011), and obtained the same results (data not shown).

Climatic variables included mean annual precipitation (MAP), mean annual temperature (MAT), precipitation seasonality measured by the Markham seasonality index (MSI) and interannual variability based on the Standardized Precipitation Index (SPI). We used the SPI to estimate the percentage of severely wet (SPIW) and dry years (SPID). The SPI is defined as the number of standard deviations above or below the climatological mean precipitation. Because we were interested in evaluating inter-annual variability, SPI values were calculated for each year as the deviations of the yearly mean precipitation from the long-term MAP for the period from 1961 to 2002 (42 years). For each pixel, we calculated the proportion of severely wet years with a SPI $\geq+1.5 \sigma$ (SPIW) and the proportion of severely dry years with a SPI $\leq-1.5 \sigma$ (SPID) (Holmgren et al. 2013). The SPI index has the benefit that, unlike other measures of variability, it has a low correlation with the mean annual precipitation. All climatic data were derived from the Climatic Research Unit (CRU) database (Jones and Harris 2013) and processed with 
Matlab. An assessment of the spatial autocorrelation of this dataset revealed high spatial dependence up to scales $>1000 \mathrm{~km}$, indicating that it adequately captures the climate patterns in our region despite its relatively large resolution.

Since soil nutrients and water holding capacity can directly influence tree growth (House et al. 2003, Mills et al. 2013), we assessed soil fertility as total exchangeable bases (TEB) using the Harmonized World Soil Dataset (FAO-ISRIC 2010) and we considered the Profile available water capacity (AWC) from the Global Gridded Surfaces of Selected Soil Characteristics (IGBP-DIS 2000).

We considered two landscape features, altitude (ALT) and distance to rivers (DR) that can affect propagule availability, resource availability and disturbance and therefore indirectly influence tree growth (Stevens 1992, Turner et al. 2004). Altitude was obtained from the Worldclim dataset (Hijmans et al. 2005). The distance to watercourses was obtained from the HydroSHED database (Lehner et al. 2006) and was discretized in two classes, below and above a distance of $1000 \mathrm{~m}$. Preliminary analysis of tree cover indicated that tree cover concentrated along rivers and decreased logarithmically with increasing distance. Little average effect of rivers was found beyond $1000 \mathrm{~m}$ (data not shown).

We assessed the effects of fire and livestock since both can strongly affect vegetation structure and composition. Mortality by fire can be especially high among tree juveniles (Bond 2008) and result in lower tree cover than climatologically possible (Sankaran et al. 2008, Staver et al. 2011). Herbivores can either directly suppress trees through grazing, browsing and trampling (Prins and van der Jeugd 1993, Holmgren et al. 2006b), or increase tree cover by suppressing grass competition with trees (Walter 1971) and facilitating seed dispersal (Brown and Archer 1999). Moreover, fire and herbivory effects can interact (Archibald et al. 2005, Holdo et al. 2009), for example if grazers 
reduce grass biomass and fire ignition, disrupting the feedback between fire and grasses and favoring trees (Scholes and Archer 1997, Van Langevelde et al. 2003, Staver et al. 2009). Cattle is the main domestic livestock present in our study regions. In southeastern South America, cattle and livestock densities are highly correlated. Pearson's correlation between cattle and tropical livestock units, where all ruminants are converted into a standard animal unit (FAO 1999), was $\mathrm{q}=0.998$. Cattle and livestock densities were obtained from the FAO Gridded Livestock of the World dataset (Wint and Robinson 2007, Robinson et al. 2014). We used data corresponding to the Gridded Livestock of the World v 2.01, since there have been improvements in the dataset (Robinson et al. 2014). FAO data from the year 2000 did not produce different results. The FAO densities are obtained by modeling the livestock densities as a function of environmental variables. This is done within subnational administrative units, and the total value per unit, corresponding to subnational statistics, is maintained. To avoid replication of nested variables in our model, we averaged the model values over the administrative unit levels corresponding to the original data (or averaged model estimates if subnational statistics were missing). Places with an altitude higher than $1200 \mathrm{~m}$ were excluded from the analysis.

Fire occurrence was derived from the MODIS MCD445A1 Burned Areas Monthly product (Roy et al. 2008) and calculated as the number of burns over a 10-year period (2000-2009). We used the quality layer in the dataset to exclude pixels classified in category 4 (less quality) and category 5 (agricultural areas), since the product is less reliable for these two classes (Boschetti et al. 2009).

All variables were re-projected using Albers equal area conical projection and resampled to a $250 \mathrm{~m}$ resolution, matching the Modis cell values. We then used the centroid of each cell to extract values. We randomly selected 10.000 points for the 
southeastern South America (SSA) region, with subsets of these points corresponding to the subtropical and the Campos region (4000 and 1000 points). For all study regions we used the Global Land Cover map (Bartholomé and Belward 2005) to filter out areas corresponding to water (GLC codes:20-21), urban, cultivated and managed areas (codes: $16,22)$ and mosaics of cultivated and natural areas (codes: 17-18). The GLC2000 was produced using the Land Cover Classification System (LCCS) methodology, which is based on a series of dichotomous phases to classify land cover, including the distinction between managed and natural areas. Managed areas include "all vegetation that is planted or cultivated with an intent to harvest [...] (e.g., wheat fields, orchards, rubber and teak plantations)" (Di Gregorio and Jansen 2000). We therefore retained natural vegetation such as non-cultivated native grasslands while leaving out cultivated areas including tree plantations.

\section{Modeling tree cover}

We used spatial models to relate tree cover to the environmental and human-related variables for the Campos and for the wider study regions in southeastern South America with the same precipitation levels. We fitted spatial models for natural areas (filtering out cultivated and managed areas and mosaics). To approach normal distributions the fractions of tree cover were arcsine-square root transformed. We used spatial generalized least squares (GLS) models with a spatial correlation structure in residuals (Zuur et al. 2009). Analyses were performed in R with the packages MuMIn, MASS, psych, nlme, lattice, gstat and graphics. We assessed five different spatial correlational structures: exponential, gaussian, linear, rational quadratic and spherical (Zuur et al. 2009). The correlational structures were assessed using the Akaike Information Criteria (AIC). Spatial autocorrelation was best accounted by an exponential decay for all study regions. 
For the SSA region, explanatory variables were not strongly correlated to each other (Pearson correlation; $\rho \leq 0.5$ ). All variables were considered in the model construction and those showing the highest correlation where tested independently. In the case of the Campos, precipitation and temperature were highly correlated (Pearson correlation; $\rho>0.85$ ), as well as precipitation with MSI and altitude (Pearson correlation; $\rho>0.5)$. These variables were analyzed independently but were not retained by the model.

GLS models with different correlational structures were ranked using AIC for the Campos, subtropical South America and the whole SSA. We compared AIC of all models composed uniquely of statistically significant variables, starting with each one of them and adding the rest through a stepwise forward selection. The model with least AIC, and with more than two units of difference with other models, was retained. The goodness of fit of the model was calculated based on the log likelihood-ratio test with the function "r.squaredLR" of the package MuMIn. The value was adjusted with Nagelkerke modification so that R2 achieves 1 at its maximum (Nagelkerke 1991).

\section{Results}

Tree cover in southeastern South America increases with precipitation and decreases with cattle density and fire occurrence (Fig. 2.1, Fig. A.2.1). These results were consistent for subtropical South America and across the wider southeastern South America (Fig. 2.1). We did not detect significant effects of temperature, rainfall variability (within or between years), soil features (nutrient availability or water holding capacity), or landscape features (distance to rivers or altitude). We found that the effects of cattle density and fire occurrence change along the precipitation gradient. At intermediate levels of mean annual precipitation (roughly between $1000-1500 \mathrm{~mm}$ ), fire occurrence is lower in sites with high 
cattle density (Fig. 2.2). In contrast, at higher rainfall (MAP > $1500 \mathrm{~mm}$ ), fire frequency increases in sites with high cattle density.

Tree cover within the Campos was best explained by the proximity to rivers (Fig. 2.1). Within this ecoregion, we did not find significant differences in tree cover that could be related to climate, soil characteristics, altitude, cattle density or fire occurrence. 


\begin{tabular}{|c|c|c|c|}
\hline \multicolumn{3}{|c|}{$\begin{array}{l}\text { Uruguayan Savanna Ecoregion (Campos) } \\
\text { (MAP: } 1000-1900 \mathrm{~mm} \text { ) } \\
\text { Final model: Tree cover } \sim \text { DR }\end{array}$} & $e^{2}+1$ \\
\hline \multicolumn{3}{|l|}{$\mathrm{R}^{2}=0.20, \mathrm{AIC}=147$} & \\
\hline Variable & Coefficient & P-values & \\
\hline Distance to rivers (DR) & 0.137 & $<0.0001$ & \\
\hline \multicolumn{3}{|c|}{ Final model: Tree cover $\sim$ MAP - CD - FO } & \\
\hline \multicolumn{3}{|l|}{$\mathrm{R}^{2}=0.41, \mathrm{AIC}=2854$} & \\
\hline Variable & Coefficient & P-value & \\
\hline $\begin{array}{l}\text { Mean annual precipitation (MAP, } \\
\text { mm) } \\
\text { Cattle density }\left(\mathrm{CD}, \text { units } \mathrm{km}^{-2}\right) \\
\text { Fire occurrence }(\mathrm{FO}, \#)\end{array}$ & $\begin{array}{l}0.0050 \\
-0.0028 \\
-0.075\end{array}$ & $\begin{array}{l}0.0009 \\
0.0001 \\
0.008\end{array}$ & \\
\hline \multicolumn{3}{|c|}{$\begin{array}{l}\text { Southeastern South America (MAP: 1000-1900 mm) } \\
\text { Final model: Tree cover MAP - CD - FO }\end{array}$} & \\
\hline \multicolumn{3}{|l|}{$\mathrm{R}^{2}=0.42, \mathrm{AIC}=5256$} & \\
\hline Variable & Coefficient & P-value & \\
\hline $\begin{array}{l}\text { Mean annual precipitation (MAP, } \\
\text { mm) } \\
\text { Cattle density }\left(\mathrm{CD}, \text { units } \mathrm{km}^{-2}\right) \\
\text { Fire occurrence }(\mathrm{FO}, \#)\end{array}$ & $\begin{array}{l}0.00025 \\
-0.0028 \\
-0.085\end{array}$ & $\begin{array}{l}0.079 \\
<0.0001 \\
<0.0001\end{array}$ & \\
\hline
\end{tabular}

Figure 2.1: Tree cover distribution and explanatory drivers. Left panel: Generalized least squares spatial models for tree cover percent (arcsine square-root transformed; Landsat data). Region of analysis expands from top to bottom. Top: Uruguayan Savanna Ecoregion (Campos); Middle: subtropical South America (delimited by Koppen-Geiger subtropical regions); Bottom: southeastern South America (delimited by $14^{\circ} \mathrm{S}, 62^{\circ} \mathrm{W}$ and the Atlantic Ocean). Mean Annual Precipitation (MAP) ranges within 1000-1900 mm in all three regions. Gray areas have precipitation levels outside the 1000-1900 mm range and were excluded from the analysis 


\section{Discussion}

Our results suggest that the extent of tree cover in southeastern South America is explained by the combined effects of precipitation, cattle density and fire occurrence. These regional patterns are consistent with local field experiments demonstrating that cattle limits seedling establishment of trees and shrubs (Oliveira and Pillar 2004, Altesor et al. 2006, Cesa and Paruelo 2011, Cingolani et al. 2014, Lezama et al. 2014, Macias et al. 2014) and with historical and field evidence from southern Brazil (Pillar and Quadros 1997). Comparable effects of cattle have been found for some African ecosystems (Bucini and Hanan 2007). Our results contribute to bridge the local experimental findings with large-scale landscape patterns, adding new evidence on the role of livestock in determining vegetation patterns in southeastern South America.

The interaction between livestock and fire is complex. On one hand, grazing by livestock can reduce fire occurrence by depleting grass fuel loadings and therefore indirectly promote woody plant encroachment. On the other hand, grazers that consume young seedlings and trample on tree juveniles can limit tree recruitment and therefore promote grasses and fire (Scholes and Archer 1997). In SSA, cattle seem to constrain fire at intermediate levels of precipitation (i.e. 1000-1500 mm; Fig. 2.2). Here cattle may be able to remove enough grass biomass decreasing fuels and fire occurrence. This may explain the outstanding low fire density that has been noted for the Campos of Uruguay even when fire is often used as a managing tool to improve pasture quality (Di Bella et al. 2006). The Campos would therefore be mostly in a "grazer-driven" state (as opposed to a "fire-driven" state), with livestock reducing biomass and fragmenting fire connectivity by maintaining grazing lawns (Leonard et al. 2010, Hempson et al. 2015b). In contrast, highly grazed sites in wetter areas (MAP > $1500 \mathrm{~mm}$ ) burn more often than sites with lower grazing pressure. A plausible explanation is that livestock maintains the 
landscape open despite levels of precipitation that would allow denser tree cover. Also intentional burning may be used as a management tool to prevent woody plant encroachment (Fearnside 1990, Mistry 1998).

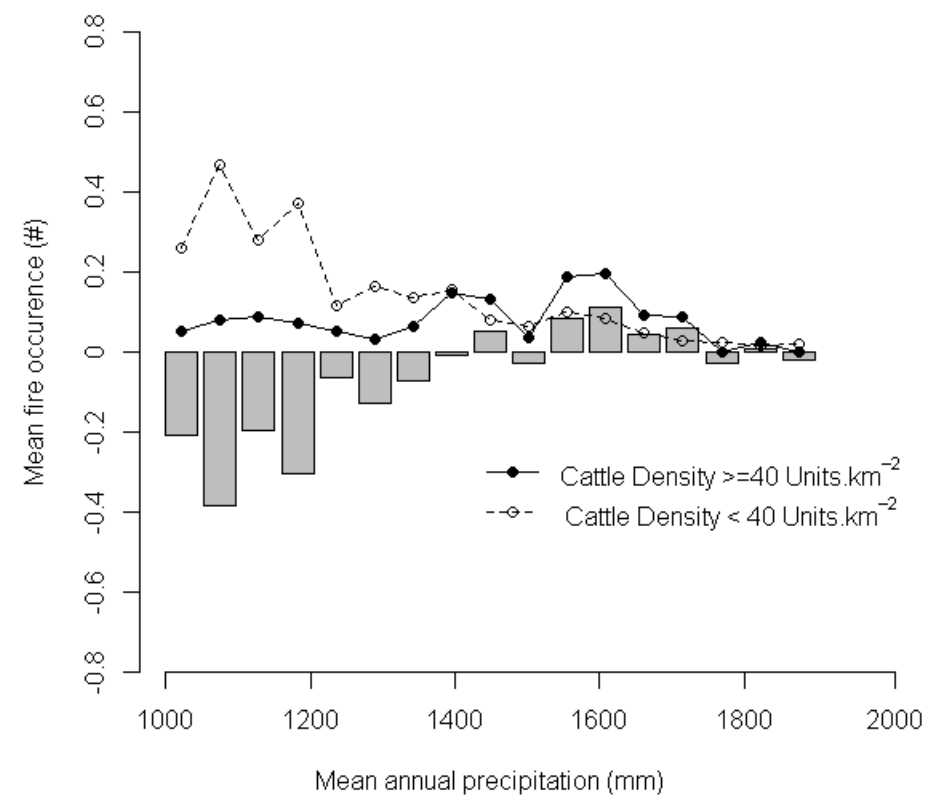

Figure 2.2: Mean fire occurrence along the gradient of mean annual precipitation in subtropical South America. Values are fire records for the period 2000-2009, averaged at 50 $\mathrm{mm}$ precipitation intervals. Bar plots show the effect of cattle on fire occurrence expressed as the difference in average fire occurrence between sites with higher and lower grazing for each precipitation interval.

The results for the Campos compared to the rest of southeastern South America highlight the importance of the scale of analysis when addressing ecological patterns and 
the putative mechanisms involved (Levin 1992, Piñeiro-Guerra et al. 2014). Our regression models did not detect any significant effects of climate or disturbance regimes on tree cover in this ecoregion, despite their significant role at the larger spatial scales. Cattle densities throughout the Campos (mean $\sim 60$ cattle units. $\mathrm{km}^{-2}$ ) are above the average in southeastern South America (mean 40 cattle units. $\mathrm{km}^{-2}$ ). Cattle is raised extensively and its loads are usually determined empirically (Deregibus 2000) which often results in overgrazing during periods of lower precipitation (Nabinger et al. 2000, Peel et al. 2007). Our results suggest that the very high cattle densities throughout the Campos region may be preventing tree cover expansion. This pattern could only be detected by comparing the effects of cattle grazing in the Campos with the neighboring areas of southeastern South America under the same rainfall levels.

Tree cover in the Campos increases closer to watercourses. The concentration of tree cover along rivers may be partly a legacy of the past, when trees may have found moister refuges during dry periods (Chaneton et al. 2012, Müller et al. 2012) when trees may have found a water- refuge along the rivers. This is consistent with the remarkably high tree and shrub species richness of this region (Haretche et al. 2012). The current distribution of trees close to rivers and creeks can therefore result from the combined legacy effect of a drier past with the present disturbance regimes imposed by livestock. We echo Chaneton et al. (2012) plea for integrating the findings in a common framework that understands current tree cover as the result of past and current filters that shape the species pool, seed dispersal, and the abiotic and biotic mechanisms that affect seedling establishment and tree recruitment. Our analysis identified key environmental filters that contribute to explain the extent of tree cover across South American grasslands. Future field experiments could evaluate the relative importance among these environmental factors across the different regions compared here. These future analyses would help also 
separating the role of functional traits since large differences in taxonomic and functional composition exist among plant communities in these regions.

Changes in tree cover on current grasslands have deep ecological and social implications. The grasslands of South America provide key ecosystem services (Barral and Oscar 2012), have high importance for agricultural production and support the majority of livestock production in the region (Suttie et al. 2005). Given the relevance of anthropogenic drivers in these grasslands, further studies to understand the mechanisms of tree cover change under different land-use practices and climate conditions could contribute to enhance the resilience of these ecosystems and sustain the provision of environmental services. Our analyses are relevant to understand the dynamics of grassy biomes on Earth's where fire and herbivory could strongly shape vegetation patterns (Bond 2005). Recent remote sensing information and global databases provide the largescale analysis needed to assess some of the missing pieces of the puzzle assembled by early ecologists.

\section{Conclusions}

Our results highlight the importance of precipitation, fire and livestock in shaping tree cover in southeastern South America. Specifically, they suggest that tree cover increases with precipitation but is limited by cattle grazing and fire occurrence. Notably, the detection of these determinants was possible only when considering complementary scales of analysis. Our results suggest that cattle grazing prevents forest expansion from rivers into subtropical grasslands despite the reduction in grass fuel and fire frequency. 


\section{Acknowledgments}

We thank M. Hirota, A. Staal and C. Xu for suggestions on data analysis and for sharing R scripts. M. Meerhoff made helpful suggestions to the text. This research was partly supported by the National Research and Innovation Agency (ANII) and the Universidad de la República (UdelaR) of Uruguay. 


\section{Appendix to Chapter $2-\mathbf{A . 2}$}

Supplementary Material to the paper Bernardi, R.E., Holmgren, M., Arim, M. \& Scheffer, M. Why are forests so scarce in subtropical South America? The shaping roles of climate, fire and livestock.

Includes:

Table A.2.1. Environmental variables used in the statistical models.

Figure A.2.1. Tree cover percent along environmental gradients in subtropical South America. 
$m$

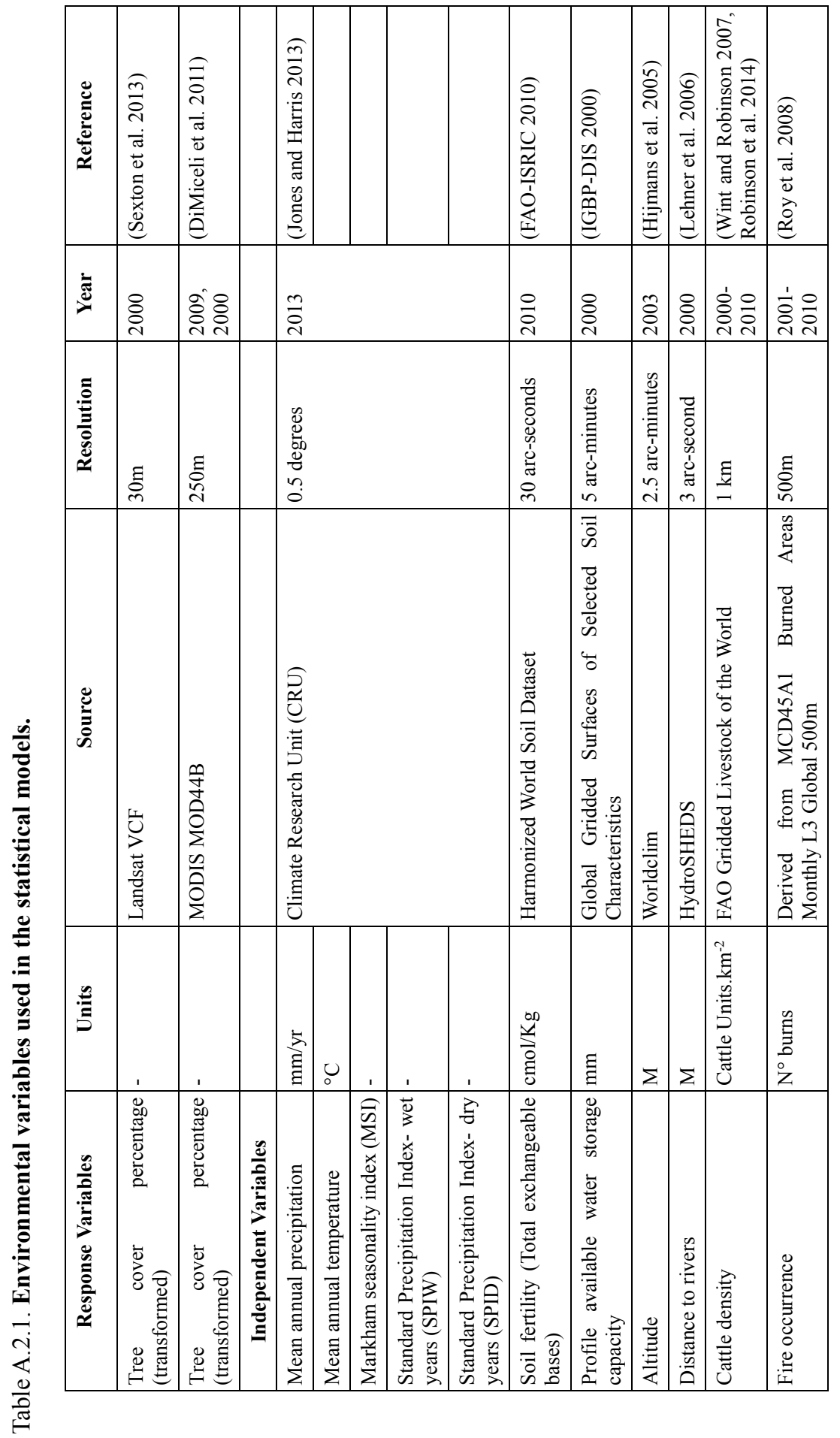


Figure A.2.1. Tree cover percent along environmental gradients in subtropical South America a)

Tree cover percent along a gradient of mean annual precipitation. b) Landsat tree cover percent as a function of cattle density. c) Landsat tree cover percent as a function of fire occurrence. Values from $1 / 5000$ random samples in a $250 \mathrm{~m}$ grid.
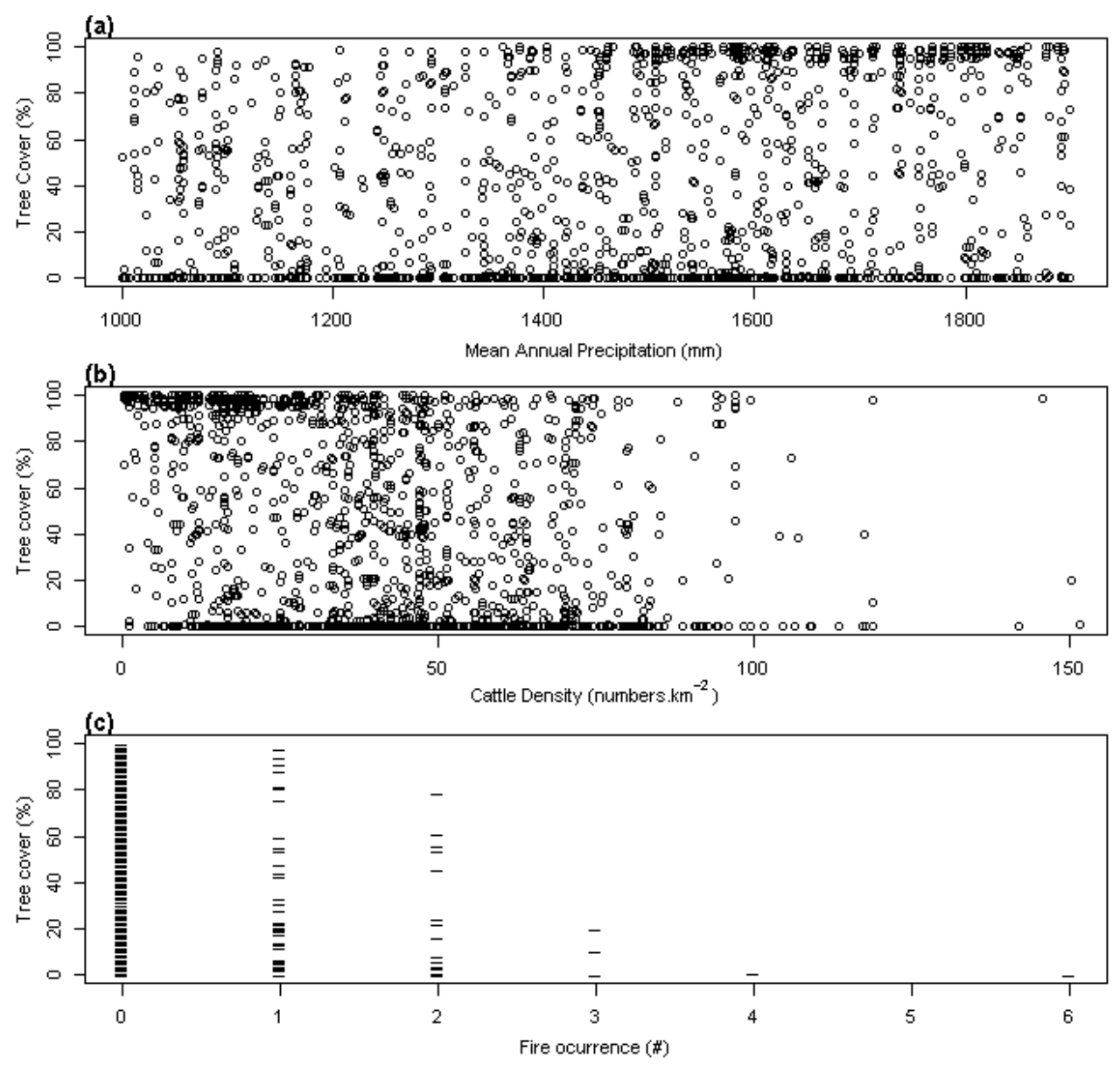


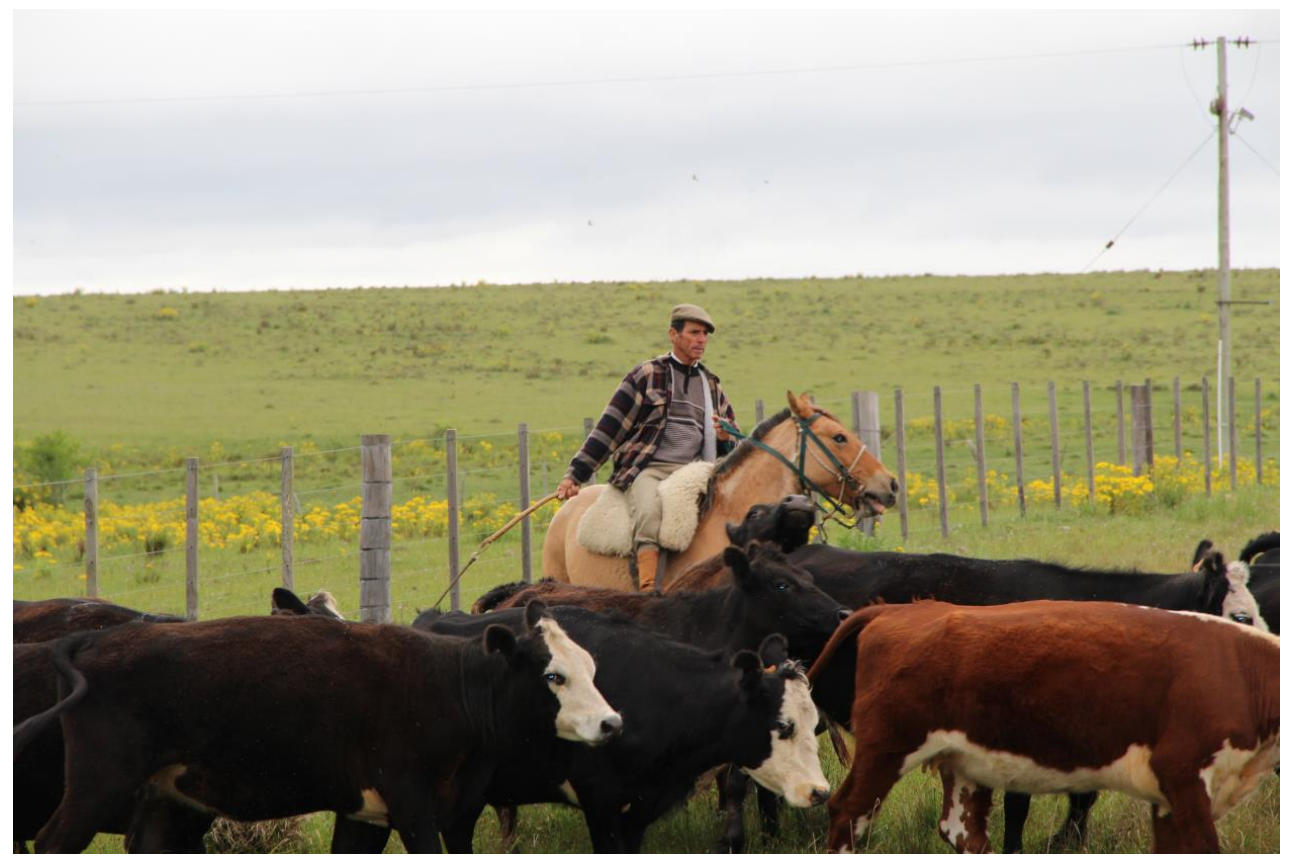

Photograph: Milena Holmgren

\section{Chapter 3}

Land use drives forest-grassland transitions in subtropical South America

Rafael E. Bernardi, Marion Buddeberg, Matías Arim, Milena Holmgren

(Submitted) 


\begin{abstract}
Grasslands and forests are prevalent across the Latin America landscapes, having a strong connection with pre-Hispanic and contemporary societies. Congruently, the land use associated with these ecosystems has a large role on economies at all scales from families to countries, shaping socioeconomic and socio-ecological organization along the Americas. Recent studies suggest that tropical and subtropical grasslands, savannas and forests represent alternative ecosystem states that can shift depending on climate and disturbance regimes. The organization of societies and its activities are major determinants of disturbance regimes and are therefore major candidates to account for ecosystem transitions. We analyzed environmental variables and the role of societies, through the changes in land use, fire regime and agricultural and livestock management, on the direction and rate of forest-grassland transitions over a forty five-year span in the Campos region, an extensive subtropical ecotone in South America. This region has remarkably low tree cover despite relatively high precipitation levels.
\end{abstract}

We found that forests increased in drier areas, possibly favored by an increase in rainfall during the last century, and decreased in areas with high cover of crop agriculture, a widespread pattern in South America. Interestingly, forests increased in grasslands where livestock densities have been reduced. The observed patterns were strongly associated to medium-scale (hundreds of $\mathrm{km}$ ) edapho-topographic conditions that broadly determined the main productive land use. Our work shows that current regimes of fire and land use, including livestock grazing can explain the large extent of grasslands, and that under present climatic conditions, changes in land use regimes can trigger transitions between grasslands and forests or savannas, with significant potential economic and ecological consequences. 


\section{Introduction}

Forests, savannas and grasslands extend through most of South America, with their distribution strongly depending on climate and disturbance regimes (Bernardi et al. 2016b). Indeed, precipitation was early identified as a confident predictor of dominant vegetation, with increasing tree cover probability as mean annual precipitation increases (Whittaker 1970, Woodward et al. 2004). However, there are ranges of precipitation in which alternative tree cover and height modes could be observed - treeless, savannas, or forests (Hirota et al. 2011, Staver et al. 2011, Xu et al. 2016). These levels of tree cover could represent alternative stable states, with transitions among them determined by disturbances and resource availability, i.e. fire (Sankaran et al. 2005, Hirota et al. 2011, Staver et al. 2011, Hoffmann et al. 2012) and herbivory regimes (Sankaran et al. 2008, Bernardi et al. 2016b), or climate variability (Holmgren et al. 2013). Despite an increasing body of work to understand these transitions, the nature of the socio-ecological context that may trigger them is still not well understood.

Understanding the determinants of forest - grassland transitions is particularly relevant on applied and theoretical grounds. From an applied perspective, these transitions could impact the production and ecosystem services of biomes, with potential positive or negative effects (Anadón et al. 2014a, Bernardi et al. 2016a). From a theoretical perspective, the very existence of transitions and identification of its determinants now represents a fundamental issue for alternative states theory in general (Scheffer 2009) and its relation with ecosystems transitions in particular (Scheffer et al. 2001).

The Campos grasslands of Uruguay have remarkably low tree cover $(\sim 6 \%)$ for their precipitation levels $(\sim 1200 \mathrm{~mm})$. Notably, the precipitation level at the Campos is within the range where alternative tree cover states are expected to be observed (Hirota et al. 2011, 
Anadón et al. 2014a). Further, this region is an ecotone between the subtropical Atlantic and Araucaria Forests in Southern Brazil and the temperate "Pampas" grasslands of Argentina. These "old-growth" grasslands of the Campos evolved during drier, colder periods in the Pleistocene that were marked by frequent droughts (Behling et al. 2007, Piovano et al. 2009, Jeske-Pieruschka et al. 2010, Puerto et al. 2013, Veldman et al. 2015). Since the Holocene, reduction of large herbivores and increased fire frequency have been observed in the Campos of southern Brazil, possibly associated to first human settlements (Behling et al. 2007, Blanco et al. 2014). More recently, since the XVI century, livestock expanded to be the dominant herbivore in these ecosystems. Humans have therefore exerted strong influence on these systems, most notably through land conversion and the modification of disturbance regimes that can affect tree cover states. Local experiments and observations have suggested that fire and livestock may be limiting forest expansion in the region (Pillar and Quadros 1997, Müller et al. 2012, Blanco et al. 2014, Bernardi et al. 2016b, Etchebarne and Brazeiro 2016). In the Campos, livestock densities are among the highest in South America and may also explain their low fire frequencies (Di Bella et al. 2006, Bernardi et al. 2016b). Despite local experiments and large - scale analysis of current tree cover distribution, to our knowledge no temporal analyses of tree cover changes, spanning large temporal and spatial scales have been performed in the region.

In this work we analyze changes in native forest cover in a 45 -year period in the Campos region of Uruguay, which covers approximately $80 \%$ of the Uruguayan Savanna Ecoregion, comprising also the Campos of southern Brazil. We attempt to identify determinants of ecosystem transitions, relating forest change to socio-ecological variables known to determine tree cover, i.e. climate, soil properties and topography, fire and livestock density, agricultural land cover and road density. 


\section{Methods}

\section{Tree cover and environmental variables}

Forest change in Uruguay was estimated as the difference in forest cover between the forest cartography of the year 2011 (MGAP 2012), based on Landsat images for that year and the first forest cartography (MGAP 1979) that was hand-drawn based on the interpretation of aerial images taken in 1966/67 (www.sgm.gub.uy). Scanned images of the first forest cartography were georeferenced, projected in the Yacaré Global Coordinate System and quality checked when original aerial images were available. We used a semi-automated procedure to convert images into polygons. The error due to drawing accuracy for a scale of 1:250.000 was estimated to be $125 \mathrm{~m}(0.5 \mathrm{~mm})$. The root mean square error of the georeferencing procedure is lower ( $40 \mathrm{~m}$ ) and can therefore be neglected (Iliffe and Lott 2008, Kramer et al. 2011). All natural forests in the first forest cartography were merged into a single category. Distortions in the alignment of the aerial photographs were corrected using rivers as reference, although some problems of alignment persisted, particularly in the north of the country, where fewer stable points for the georeferencing were available (due to less settlements and roads). These problems did not affect the total forest cover area. We did not considered commercial tree plantations for any year. Analysis were done using the administrative land units of the Agricultural Census, considering each unit a data point. We excluded census units with a surface area below $100 \mathrm{~km}^{2}$ or with urban land cover above $20 \%$ to exclude periurban areas. A total number of 184 units were included in the analysis, with an average Area of $850 \mathrm{~km}^{2}$ $\left(\mathrm{SD} \pm 490 \mathrm{~km}^{2}\right)$

We related forest cover change to climate, soil and topography, land use and disturbance variables (Table A.3.1). Climate variables were averages for the period 1950 - 2000 (Hijmans 
et al. 2005). We used mean annual precipitation and mean annual temperature as known determinants of tree cover (Whittaker 1970, Walter 1971). Coefficient of variation, precipitation of the driest quarter and temperature of the hottest quarter were included as indicators of seasonality and interannual variability, which can have an effect on tree cover in South America (Holmgren et al. 2013). We used two widely used national soil indexes: the soil productivity index CONEAT (Duran 1987) and the water holding capacity index (Molfino and Califra 2001). Altitude and slope where obtained from the national database of the Ministry of Agriculture and Fisheries (MGAP - http://www.snia.gub.uy/). In Uruguay, forests are mostly associated to rivers (Bernardi et al. 2016b). Therefore, we considered river density as a potential explanatory variable. River density was derived from the HYDROSHED database (Lehner et al. 2006). We considered road density as an explanatory variable because it is strongly associated to population and urban development (Cai et al. 2013). The road layer was obtained from the Ministry of Transportation and Public Works (MTOP http://www.snia.gub.uy/), and road density was calculated with the Kernel density function in Arcmap. Agricultural cover, a main driver of forest change, was derived from the land Cover LCCS map (MVOTMA-MGAP-FAO 2008). Cattle and sheep densities for each census unit for the period 2000-2011 where obtained from census data: (http://www2.mgap.gub.uy/ portal/page.aspx?2,diea,diea-principal,O,es,0). Livestock values where expressed in livestock units (LU) of $380 \mathrm{~kg}$ equivalent standard weight. General conversion to livestock units for cattle was 0.75 LU/animal and for sheep 0.17 LU/animal. Specific conversion factors were used for each development stage of animals when available (Saravia et al. 2011). Average decadal livestock values in the 1996-2011 period were obtained from the National Agricultural Census for the 19 departments of the country and assigned to the census units of each department to obtain changes in livestock densities. Fire frequency was derived from the MODIS MCD445A1 Burned Areas Monthly product (Roy et al. 2008). 


\section{Data analysis}

To capture the main landscape features and their associated vegetation communities we used existing classifications of seven major edapho-topographic sub-regions of the country (Panario 1988, Modernel et al. 2016) (Fig. A.3.1). Each census unit was assigned to the subregion that covered most of its surface. These sub-regions were clustered in two groups with agricultural cover above or below the national median value $(\sim 5 \%)$. We used ANOVA and $\mathrm{t}$ tests to test for forest cover change differences between these two regions with the stats and t.test packages in R. Low agricultural areas included "Eastern Sierras" hill formations of the east and northeast of the country, and the "Gondwanic sediment" northeast regions. It also included the "Basalt" region, characterized by shallow soils over a basaltic geologic substrate (Modernel et al. 2016). These regions are predominantly used for extensive livestock grazing and have had less expansion of agriculture due to their relatively less productive soils. High agricultural areas included the more productive soils of the west ("West Sediment") and the south ("Cristaline Shield" and "Graven Santa Lucía"), where most of the crop agriculture is grown, and the plains of the Merin Lagoon ("Graven Merín") to the east of the country which have high cover of rice agriculture.

To relate tree cover change to explanatory variables we used a Generalized Linear Model and the package bestGLM in R version 3.2.3 (McLeod and Xu 2011). Models were compared using the Akaike Information Criteria (AIC). Plots show the relationship of tree cover change with the predictor variables included in their respective models, and by ranking models by their Akaike information criterion (AIC) indices. Dependent variables in plots were transformed using the regression parameters, a method equivalent to the standard approach consisting of plotting the partial residuals to visualize the effect of each single predictor variable (Sibly et al. 2012). 


\section{Results and discussion}

Our analysis of forest cover change between 1966 and 2011 shows a relatively small increase in forest cover $(\sim 5 \%)$ over the 45 -year period. This increase would be congruent with recent studies indicating a general trend of woody expansion occurring in the Campos and Pampas (Baldi and Paruelo 2008, Gautreau 2010, Müller et al. 2012) and also globally (Brown and Carter 1998, Bond 2008, Gartzia et al. 2014, Stevens et al. 2017). Models oriented to predict vegetation change from climate trends also support these empirical results (Cramer et al. 2001). However, we found that this limited forest expansion has not occurred across the whole Campos of Uruguay. Indeed, forest loss was observed across the west and southwest of the country, and in the plains of the Merín lagoon to the east. These are regions with high agricultural cover, and forest cover reductions were likely a result of the land conversion. Uruguay has increased its agricultural crop production in the study period (from roughly 700.000 ha in 1970 to over 1.7 million in 2010) (DIEA-MGAP). Our analysis further indicates a clear spatial structure in forest cover change. Besides the decrease in forest cover in the agricultural areas in the west of the country, we observed an increase in tree cover in the Eastern regions, mostly in hills and coastal plains (Fig. 3.1).

These patterns can indeed be explained by land use and environmental variables (Fig. 3.1): forest change was negatively associated to agricultural cover $(\mathrm{p}=0.010)$, and positively correlated with slopes $(\mathrm{p}=0.015)$, road density $(\mathrm{p}=0.032)$ and drier regions $(\mathrm{p}<0.001)$. 


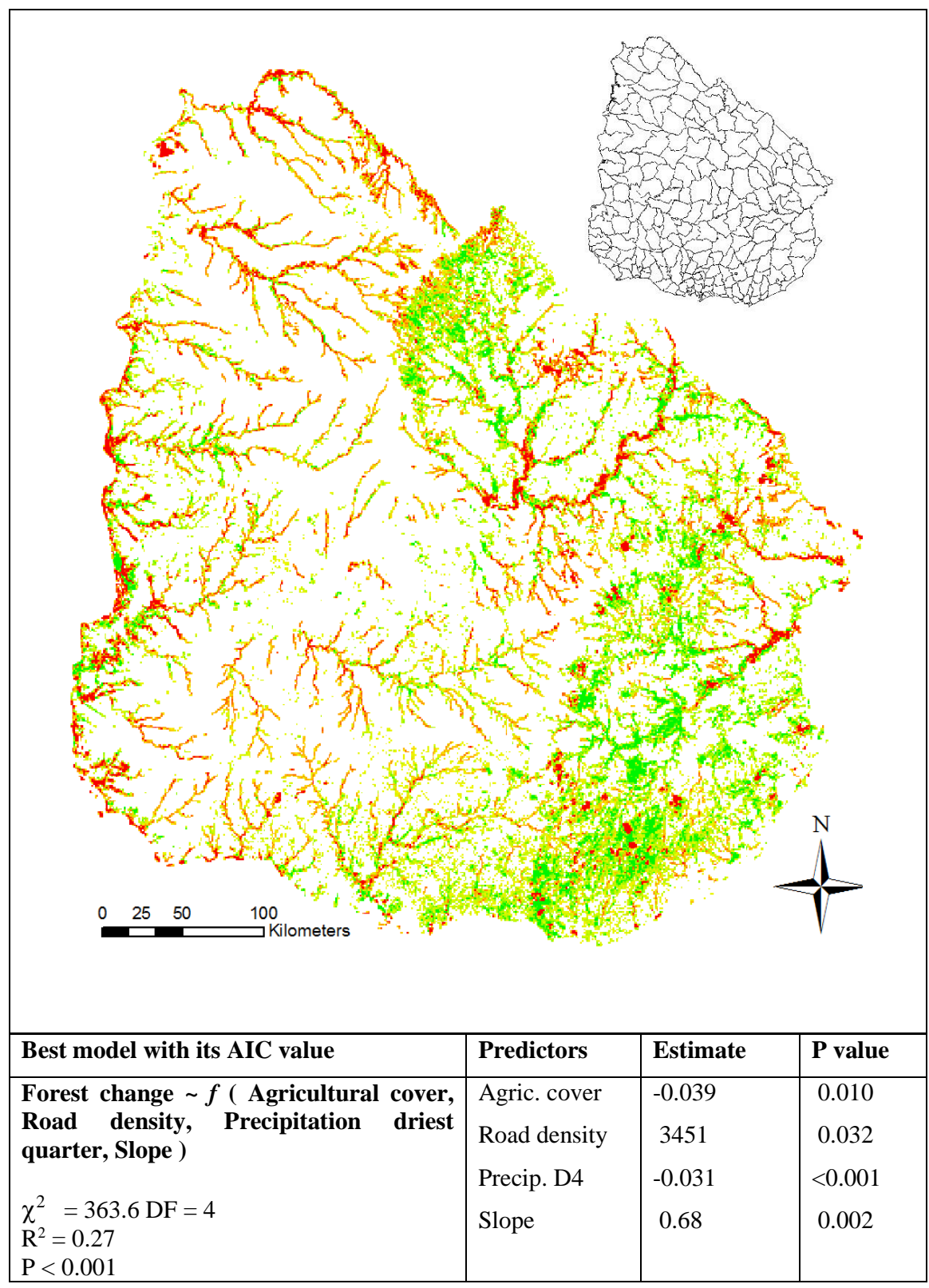

Figure 3.1. Forest cover change in Uruguay (1967-2011) and explanatory drivers. Areas with forest loss in red and forest gain in green. Upper right map: census regions used as analysis units. 
Agriculture was as a main determinant of the rate of change in forest cover, but we also analyzed it as an environmental variable related with changes at a larger scale. Forest cover change significantly differed between edapho-topographic regions with agricultural cover above and below the median country value $(\mathrm{t}=2.29, \mathrm{DF}=182, \mathrm{p}=0.023)$ (Fig. 3.2). In regions with relative high agriculture cover, represented by alluvial plains of the Uruguay river and the Merín lagoon and the granitic formations at the center-south, forest cover decreased with agricultural cover $(\beta=-0.055, \mathrm{p}=0.0011)$ and with precipitation in the drier quarter $(\beta=-$ 0.033, $\mathrm{p}<0.0001)\left(\chi^{2}=115.2, \mathrm{DF}=2, \mathrm{R}^{2}=0.24, \mathrm{p}<0.001\right)$ (Fig. 3.2). Regions with relative low agriculture cover comprised the hills to the east and northeast of the country and the shallow basaltic regions of the northwest. There, forest cover increased with slope $(\beta=1.20$, $\mathrm{p}<0.001)$, and decreased with mean annual precipitation $(\beta=-0.014, \mathrm{P}<0.001)$ and with livestock change $(\beta=-0.21, \mathrm{p}=0.034)\left(\chi^{2}=335.13, \mathrm{DF}=3, \mathrm{R}^{2}=0.39, \mathrm{p}<0.001\right)$ (Fig. 3.2). These regions are predominantly used for extensive livestock grazing and have had less expansion of crop agriculture due to their relatively less productive soils. 


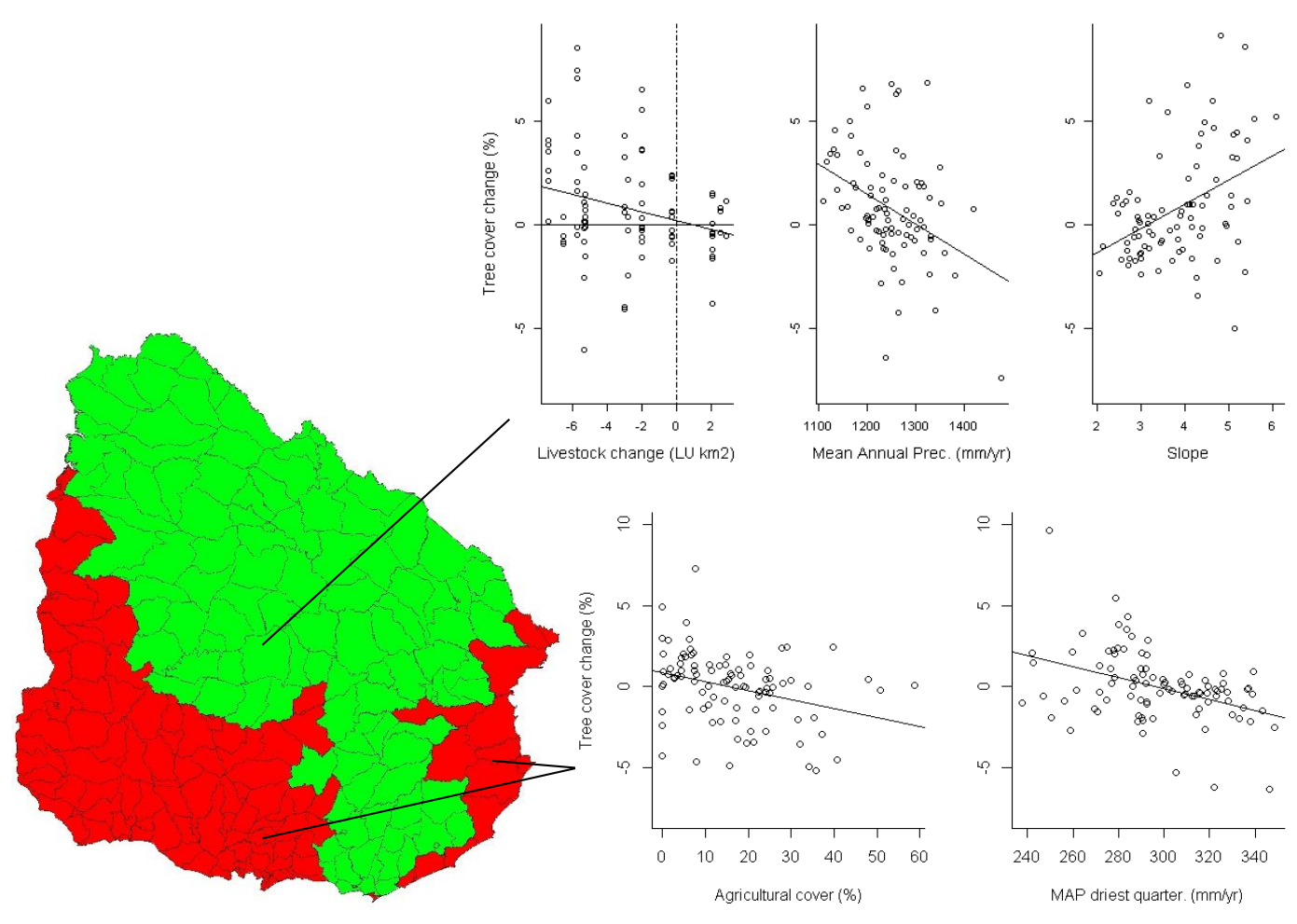

Figure 3.2. Forest cover change and drivers in regions below (green) and above (red) median agricultural cover. Census Units of Uruguay were grouped into seven edapho-topographic regions that where classified into two categories.

Dividing the Uruguayan Campos in regions with agricultural cover above or below the median country values improved our understanding of environmental determinants associated to the main medium-scale patterns of forest cover change. The increase in forest cover in areas with steeper slopes was significantly associated to a reduction in livestock densities likely explained by the expansion of forests in the hills of the east and northeast of Uruguay (Fig. 3.1). Despite an overall increase in livestock numbers for the country during the study period, there has been a large decline in sheep densities due to market restrictions and changes in agricultural practices (Montossi et al. 2013). This decline has resulted in net livestock density 
reductions in rocky outcrops and hilly areas where replacement of sheep by cattle is not possible. This release of top-down control by herbivores is likely driving the expansion of forests observed in these regions. In addition, this process may have been enhanced by rocky outcrops and steep slopes that can protect seedlings from grazing at early stages (Müller et al. 2012, Gartzia et al. 2014).

Forest cover also increased in areas with high road density. This increase was mainly associated to coastal, more urbanized regions. The association between urban areas and increased access and tree cover expansion has been reported for the Campos and Pampas, where tree species planted for domestic or productive uses (in fences and refuge for livestock) have included invasive species, whose expansion into grasslands and native forests is raising significant concern (Carrere 2001, Nebel 2006, Chaneton et al. 2012, Müller et al. 2012). Indeed, the pattern of spread of invasive species associated to coastal, highly populated regions has been detected both for animal and plant species in the Campos (Masciadri et al. 2010).

Areas with lower mean annual precipitation and lower precipitation in the driest quarter also showed an increase in forest cover. However, our data is not conclusive in this regard, and temperature has a relatively high correlation with mean annual precipitation and precipitation in the driest quarter, making it difficult to discern their effect. A plausible explanation would be that drier areas have lower agricultural potential. However, that is not the case in our study region, where the highest agricultural cover occurs in the relative drier regions of the southwest (Pearson correlation between MAP and agricultural cover is $\rho=-0.4$ ). A perhaps more plausible explanation can be that a general increase of $\sim 10 \%$ in precipitation in the country during the period has favored tree growth, particularly in those regions where the precipitation in the driest quarter is lower. This would be consistent with global trends of woody encroachment into grasslands, potentially driven by changes in climate and atmospheric chemistry (Naito and Cairns 2011, Ratajczak et al. 2012, Stevens et al. 2017). 
Our results suggest that transitions of grasslands into forests can occur under present climate scenarios. However, this general trend largely depends on land use conditions, since in extensive areas a reduction in forest cover associated to agricultural land conversion is still the dominant phenomena. We show a historical trend which is consistent with a large scale picture across South America, where an expansion of forests due to current climate conditions may be prevented by agriculture and livestock.

Ecosystems can be strong determinants of the social and economic characteristics of societies. In turn, societies can shape ecosystems through economic and social activities. In particular, by altering disturbance regimes, land use changes can have major impacts on these coupled socio-ecological systems (Liu et al. 2007). We hope that our results provide a better understanding of the implications of land use changes in terms of forest-grassland transitions in subtropical South America. 


\section{Appendix to Chapter 3 - A.3}

Table A.3.1. Environmental and socio-economic variables

Fig A.3.1. Edapho-topographic regions of Uruguay 


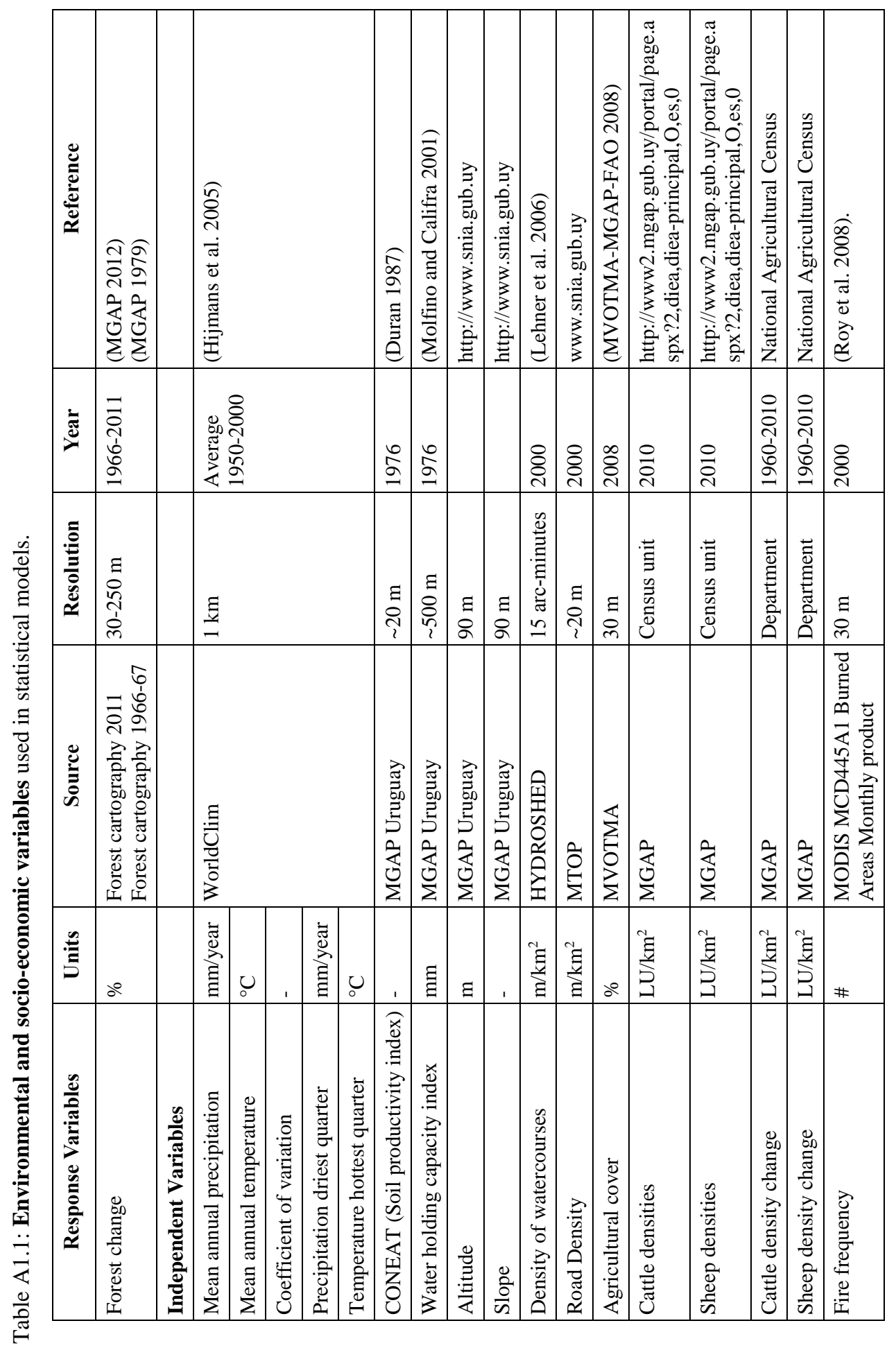


Fig A1.1. Edapho-topographic regions of Uruguay used in the statistical analysis. Based on Modernel et al. (2016) and Panario (1988).

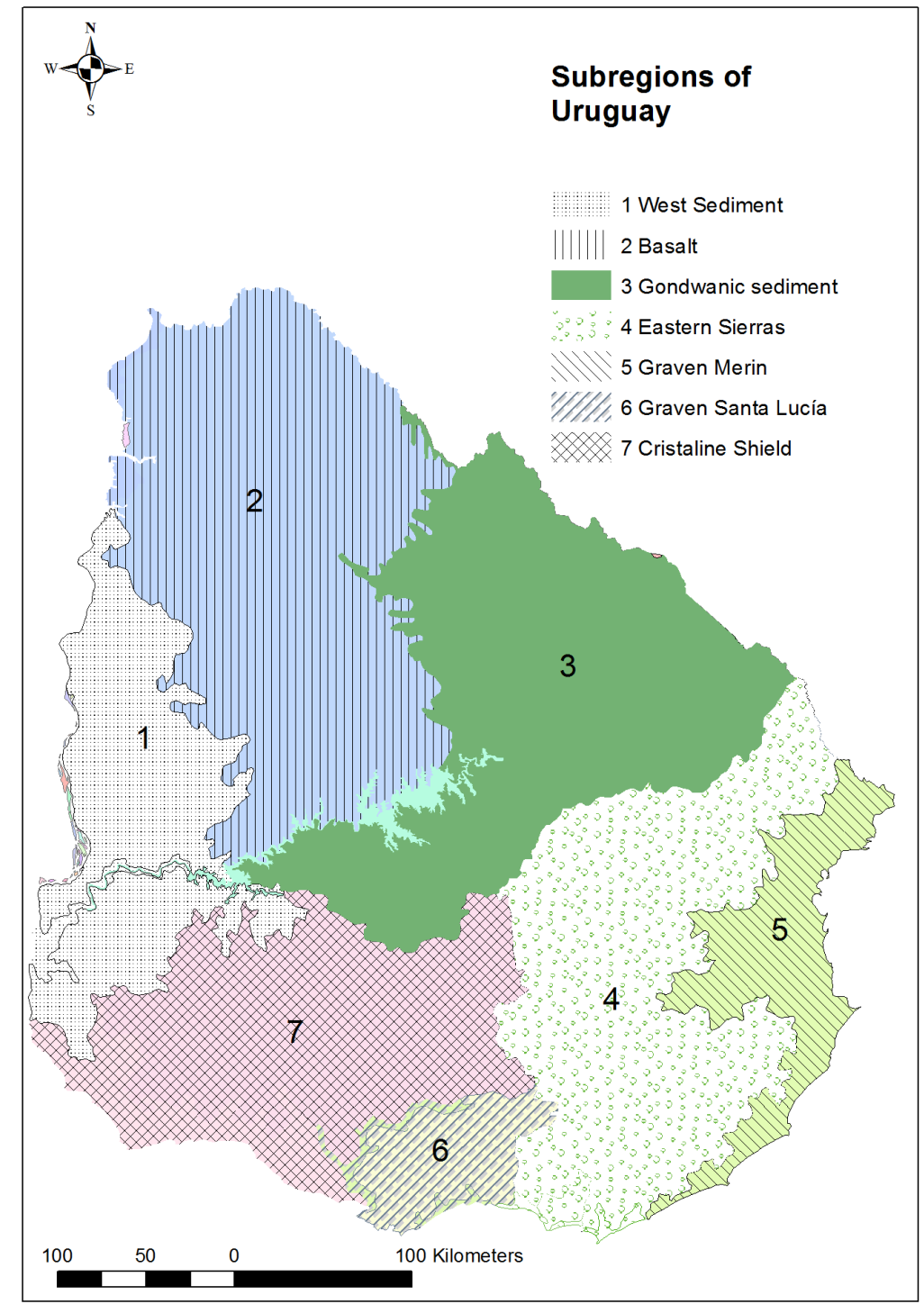




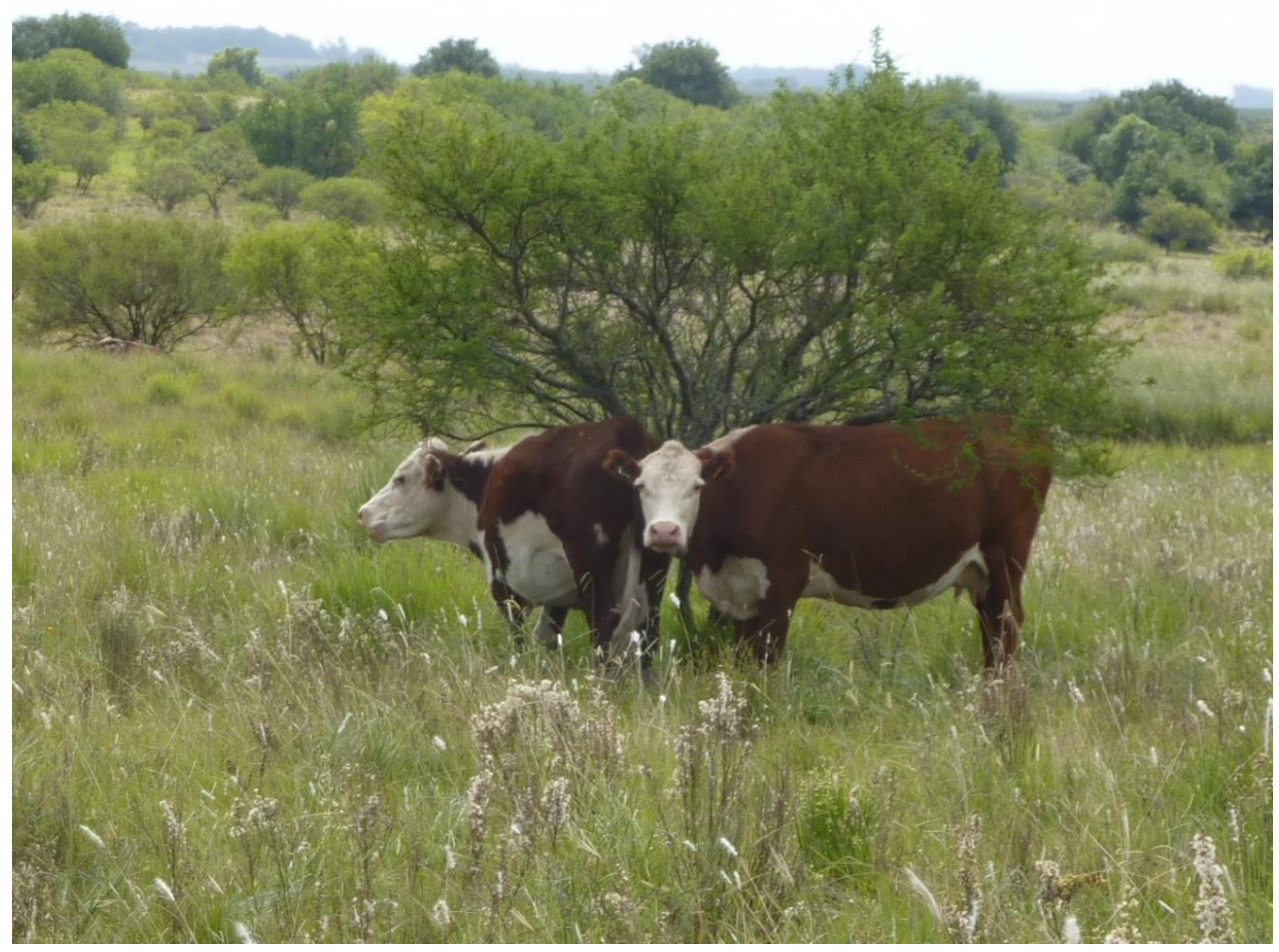

Photograph: Rafael Bernardi

\section{Chapter 4}

Trees improve forage quality and abundance in South American

\section{subtropical grasslands}

Rafael E. Bernardi, Inger K. de Jonge, Milena Holmgren

Published in Agriculture, Ecosystems and Environment.

Bernardi R.E., I.K. de Jonge, and M. Holmgren. 2016. Trees improve forage quality and abundance in South American subtropical grasslands. Agriculture, Ecosystems and Environment. 232:227-231. 


\begin{abstract}
Woody plant expansion into rangelands has raised widespread concerns about the potential impacts on livestock production. However, the way in which trees influence the structure, composition and dynamics of herbaceous communities may vary widely depending on local conditions. We studied the effects of trees on the sub-humid grasslands of Uruguay, in southeastern South America, comparing the abundance, diversity and nutrient composition of the herbaceous plants growing under the canopy of isolated trees with those growing at adjacent open places. We analyzed the vegetation patterns at increasing distances from the edge of riparian forests, where tree cover is highest, into the open grasslands. We did not find significant differences between the total biomass of the herbaceous layer growing under and outside tree canopies, but the relative abundance of $\mathrm{C} 3$ grasses doubled under trees. Nitrogen content of grasses growing under tree canopies was significantly higher than in adjacent open grasslands, whereas no significant differences were found in P or fiber content. Our results suggest that scattered trees in subtropical grasslands can increase the abundance of high quality forage and contribute to improve the provisioning services of these rangelands.
\end{abstract}

Key-words: Facilitation, grassy biomes, livestock, savannas, Uruguay, woody plant encroachment.

\title{
Introduction
}

Woody plant expansion into "old-growth" grasslands (Veldman et al. 2015) has raised global concern as shrubs and trees may change the biodiversity and dynamics of these systems and compromise their use as extensive rangelands (Chaneton et al. 2012, Anadón et al. 2014b, Bond 2016). 
Trees can affect herbaceous communities through a complex interplay of direct and indirect effects on microclimatic conditions, soil properties, herbivore behavior, and disturbance regimes (Holmgren et al. 1997, Scholes and Archer 1997, Callaway 2007, Dohn et al. 2013). Trees can directly facilitate the growth and survival of herbaceous plants by ameliorating stressful abiotic conditions and improving resource availability through various mechanisms including reduction of air temperature and soil water evaporation (Belsky et al. 1993), pumping water from deeper soil layers by hydraulic lift (Neumann and Cardon 2012), and fixing nitrogen (Stacey et al. 1992). Trees can also indirectly change water and nutrient availability through changes in soil biota that enhance water infiltration and decomposition of organic matter and nutrient release (Huxley 1999). Effects of trees on grasses may often be dependent on herbivore behavior, since herbivores can be attracted by the tree shade, increasing deposits of urine and feces under the tree canopy (Treydte et al. 2009) and can, depending on their diet selectivity, graze under the trees. Alternatively, some trees can reduce grazing pressure if the tree architecture and morphological features limit herbivore accessibility, offering a refuge to grasses (Gómez-Aparicio et al. 2008).

The effects of trees on the grass layer can be very significant in extensive rangelands, where native grasses are the primary forage for livestock. Trees can impact livestock productivity through forage production and quality, as has been observed in savannas in Africa (Weltzin and Coughenour 1990, Belsky and Amundson 1992, Treydte et al. 2007, Ludwig et al. 2008) and South America (Peri et al. 2016), in eucalyptus woodlands in Australia (Jackson and Ash), and temperate oak savannas in North America and Europe (Jackson et al. 1990, GeaIzquierdo et al. 2009). Trees can affect nutrient content of grasses and their abundance. Nitrogen content in forage is an indicator of protein concentration, a key determinant of forage quality for ruminants (Van Soest 1994). The modification of environmental conditions under tree canopies can also change the species composition in the grass layer. For example, trees 
may favor the growth of C3 grass species in mixed C4-C3 grasslands (Scholes and Archer 1997, Peterson et al. 2007). C3 grasses commonly contain higher nitrogen content than C4 grasses (Barbehenn et al. 2004). Also, since C3 grass species can maintain a higher growth rate during the winter seasons, their presence can increase forage abundance when overall grass productivity is lower (Ode et al. 1980).

We assessed the effects of trees on the herbaceous layer of subtropical South American grasslands along a gradient of cattle density to test the hypotheses that a) the abundance of $\mathrm{C} 3$ herbaceous species increases underneath the tree canopy and b) plant nutrient content increases in herbaceous plants growing in the understory of trees.

\section{Materials and methods}

\section{Study region}

We worked alongside the river Yí in the proximities of the city of Durazno in central Uruguay $\left(33^{\circ} 22^{\prime} \mathrm{S}, 56^{\circ} 31^{\prime} \mathrm{W}\right)$. These grasslands are mainly used for extensive livestock production (Panario 1988, Gallego 2008). Mean annual precipitation (1980-2009) is $1300 \mathrm{~mm}$ with no distinctive seasonality although interannual variability in rainfall is high and droughts occur frequently (Berretta et al. 2000, Castaño et al. 2011). Mean annual temperature (1980-2009) is $17.7^{\circ} \mathrm{C}$ with mean summer temperature of $22.6^{\circ} \mathrm{C}$ and mean winter temperature of $12.9^{\circ} \mathrm{C}$. Winter frosts occur periodically (40 mean annual frosts during May-October) (Castaño et al. 2011). Soils in the region have high organic content, mid to heavy texture and are well to moderately drained (MGAP 1976). Fire occurrence in the region is very low (Di Bella et al. 2006).

We selected twelve fenced sites exclusively used for cattle management (mean size $=$ 180 ha, ranged 52-359 ha). Cattle density was defined as the average cattle numbers in each paddock during the last two years and converting the weight of animals of different growth 
stage and sex into standard cattle units (Saravia et al. 2011). Cattle density ranged between $0.36-1.1$ cattle units $\mathrm{ha}^{-1}$.

\section{Vegetation sampling design}

In each site, we randomly placed a $300 \mathrm{~m}$ long, $20 \mathrm{~m}$ wide transect, perpendicular to the river, from the forest edge into the grasslands. In this region, forests are confined to the river margins forming a narrow and well-defined strip. Transects were divided in blocks of $60 \mathrm{~m}$ long. In three blocks (centered at 30,150 and $270 \mathrm{~m}$ from the forest edge), we selected the closest isolated tree to the block center. We found mostly Acacia caven $(\mathrm{n}=30)$, and scattered individuals of Prosopis affinis $(\mathrm{n}=2)$, Celtis tala $(\mathrm{n}=1)$, Schinus molle $(\mathrm{n}=1)$, and Scutia buxifolia $(\mathrm{n}=1)$. Mean tree height was $3.2 \mathrm{~m}$ and mean canopy diameter $4.5 \mathrm{~m}$. We sampled only isolated trees with no neighboring trees within a distance of at least twice the canopy diameter. To study the herbaceous communities under and around each tree, we laid two ( 0.5 $\mathrm{x} 0.5 \mathrm{~m}^{2}$ ) plots facing south from the tree stem. One plot was placed under the tree canopy at a distance of half the canopy radius from the trunk. The second plot was placed in the open grassland at one and a half canopy diameter from the trunk. Sampling was performed in autumn (April-May).

The herbaceous community in the plot was identified at the genus or tribe level and classified into the following categories: C3 grasses, C4 grasses, graminoids (including Cyperaceae and Juncaceae), forbs, and dead biomass. We estimated the relative cover of each plant group with the phytosociological method of Braun-Blanquet (1932) using a modified scale of categories where species with low number of individuals were assigned interpreted cover values (Van der Maarel 1979). We considered median values for each category for statistical analyses. All plants in the plot were clipped at ground level, dried at $65^{\circ} \mathrm{C}$ for 48 hours and weighted to assess dry biomass prior to performing the nutrient content analyses. 


\section{Plant nutrient analyses}

We determined total nitrogen $(\mathrm{N})$ and total phosphorus $(\mathrm{P})$ in the plant material of the herbaceous layer. We also determined fiber content which determines forage digestibility and intake (Van Soest 1994). Nitrogen and phosphorus concentrations were determined using a modified Valderrama method (Valderrama 1981). Fiber content was determined as amylasetreated neutral detergent fiber (NDF) corrected for ashes with Ankom technology (Fiber Analyzer 200, Ankom Technology Corporation, Fairport, N.Y) in a sequential form (Van Soest et al. 1991).

\section{Statistical analysis}

We used mixed linear models to assess the effect of tree canopy on species composition and nutrient content of the herbaceous community. Mixed effect models allow including complex nested designs and the effects of random variables (Zuur et al. 2009). The response variables were the proportion of $\mathrm{C} 3$ grass biomass over total biomass, the proportion of $\mathrm{C} 4$ grasses over total biomass, the nutritional values of plant biomass (as total $\mathrm{N}$ and $\mathrm{P}$ ) and fiber contents (as NDF). The fixed structure of our initial model included tree canopy (TC), distance to forest (DF) as well as their interactions and cattle density (CD). We included transect site (T) as a random component, and considered a potential effect of the transect site on regression coefficients of TC and DF (Zuur et al. 2009). Analysis was performed in R version 3.2.3 with the nmle package, using gls and mle functions.

Statistical models were compared using AIC and ANOVA. A model with an additional term was retained when it decreased the AIC by more than two units. Significant differences between models were also analyzed using ANOVA. We also tested the best models using the likelihoods (Akaike weights) expressed as probability (Burnham and Anderson 2004) between 
the different models with the best (or no) random structure. Response variables were tested for normality using the Shapiro-Wilk test (function shapiro.test) and plots of residuals using the function ggplot in R (package Ggplot2). Variables were transformed to meet normality of residuals if needed. Proportion of C3 grass biomass was arcsine square-root-transformed and total $\mathrm{N}$ concentration was log-transformed.

To relate the species composition of the herbaceous communities with the environmental conditions, we performed a constrained Redundancy Analysis (RDA) relating the species cover data to our environmental factors in CANOCO version 5 (Ter Braak and Smilauer 2012). A linear method was selected based on the highest gradient of genera turnover along the ordination axis. We included transect site as a covariate and included tree presence, distance to forest, tree density (expressed as trees $/ \mathrm{m}^{2}$ in each $60 \times 20 \mathrm{~m}$ block) and relative altitude (plot altitude over mean transect altitude) as environmental variables. Species data was centered and sample data were centered and standardized. (Lepš and Šmilauer 2003). We focused our analysis on the most abundant species excluding grass genera present in less than $5 \%$ of the plots, to avoid disproportionate weight of environmental correlations to rare occurrences (McGarigal et al. 2013). This has little effect on the ordination since the method relies heavily on more abundant species (Lepš and Šmilauer 2003). Adding the most infrequent species did not yield substantial differences in results.

\section{Results}

\section{Species composition}

Total herbaceous biomass was not significantly different under the tree canopy and the open grassland (Fig. 4.1a). Yet the relative abundance of C3 vs. C4 grasses shifted under tree canopies. The proportion of $\mathrm{C} 3$ grasses in the total herbaceous biomass doubled under tree canopies compared to open grasslands (Fig.4.1b, $\mathrm{p}=0.04$ ) whereas the proportion of $\mathrm{C} 4$ 
grasses was marginally higher in open grasslands Fig. 4.1c, $\mathrm{p}=0.087$ ). This increase in $\mathrm{C} 3$ biomass under trees did not depend on the distance to the forest edge or cattle density (Table A.4.1).
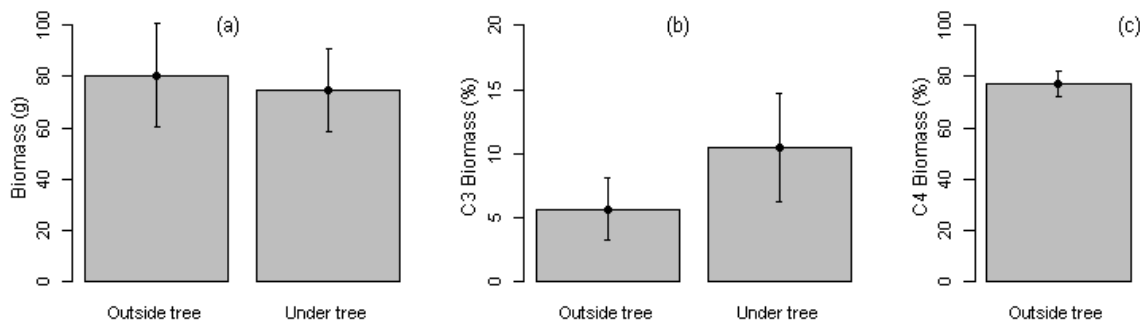

(c)
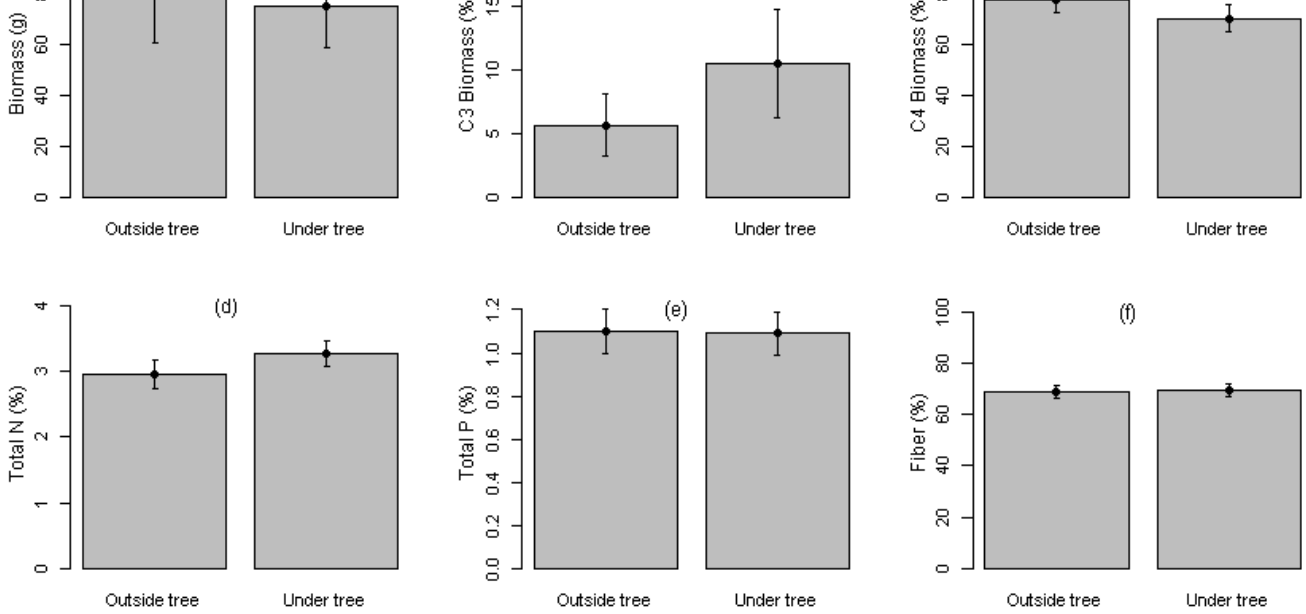

Under tree

Figure 4.1. Biomass and nutrient content under the tree canopy and in open grassland. (a) Total herbaceous biomass, (b) $\mathrm{C} 3$ grass biomass proportion, (c) $\mathrm{C} 4$ grass biomass proportion, (d) total Nitrogen, (e) total Phosphorus and (f) Fiber content. Overall means ( \pm SE) are plotted.

In general, the abundance of $\mathrm{C} 3$ grasses tended to increase further away from the forest edge, and was related to site characteristics beyond the explanatory variables we studied (Table A.4.1). Higher cattle density was only correlated with a reduction in total biomass $(p=0.013)$ but did not affect the relative abundance of either $\mathrm{C} 3$ or $\mathrm{C} 4$ grasses (Table A.4.1).

Seventeen grass genera were present in more than $5 \%$ of the plots, from a total of twenty four grass genera identified (Table A.4.2). All 17 genera were present in the open grasslands and 16 genera were present under tree canopies. The average cover of seven grass genera, forbs 
and graminoids increased under trees, while ten grass genera had a higher average cover in open grassland. The most abundant C4 genus, Paspalum, decreased under the tree canopy. This was coupled with an increase of Panicum, Axonopus and Stipa (Table A.4.3). This pattern can be observed in the multivariate analysis (Fig. 4.2). Paspalum is positively correlated with open plots, while Axonopus and Panicum and the most abundant C3 genus Stipa together with Danthonia were mostly correlated to under-canopy plots. A main axis of variability in our plant groups was determined by distance from the forest edge, which was generally correlated with increasing relative height and decreasing tree density. Forbs showed a marked variability along this ordination axis, increasing closer to the forest edge. The environmental variables included in the RDA analysis accounted for $20 \%$ of the total plant community variation $(p=0.002)$ (Table A.4.4).

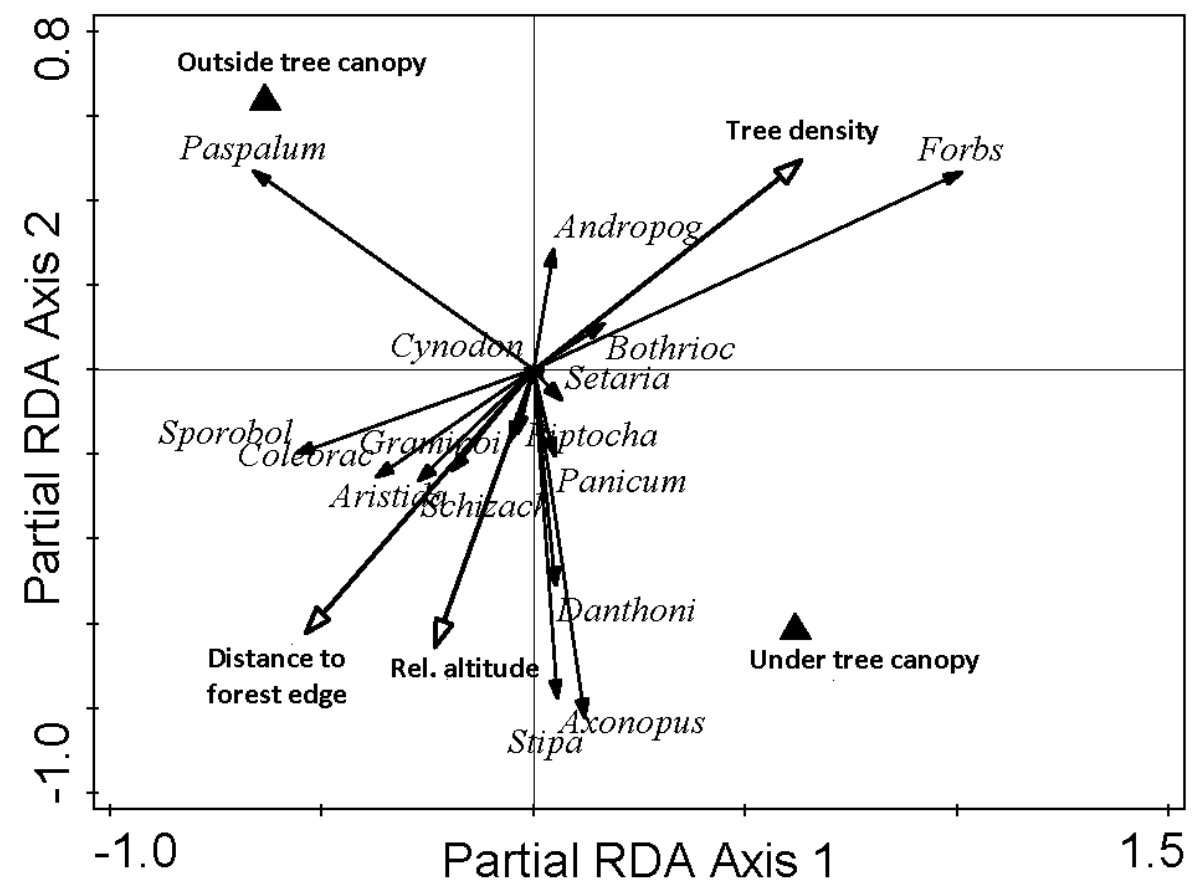

Figure 4.2. Species occurrence along environmental variables. Redundancy Analysis (RDA) species-environmental variables biplot. 


\section{Plant nutrient content}

Total plant $\mathrm{N}$ was higher in herbaceous plants growing under tree canopies $(\mathrm{p}=0.026)$ (Fig. 4.1d; Table A.4.1). The positive effect of tree cover on total plant $\mathrm{N}$ was detected for both $\mathrm{C} 3$ and $\mathrm{C} 4$ grasses $(\mathrm{p}=0.028$. and $\mathrm{p}=0.096$ respectively). Nitrogen content was also higher in $\mathrm{C} 3$ than in $\mathrm{C} 4$ grasses $(\mathrm{p}=0.004)$ irrespective of tree canopy, distance to the forest edge, or cattle density.

Total plant $\mathrm{P}$ and fiber content did not differ between plants growing under trees and those in open grassland (Figs. 4.1e and f respectively). $\mathrm{P}$ increased and fiber content decreased closer to the forest edge. We could not detect any changes on plant nutrient or fiber content related directly to cattle density. We found significant differences in N, P and fiber across sites that could not be explained by the variables we studied (Table A.4.1).

\section{Discussion}

We found significant differences in species composition and plant nutrient content in the grass layer underneath tree canopies. The abundance of C3 grass doubled under the shade of trees. Trees reduce irradiance and temperature in summer which likely favors C3 over C4 plants, since C3 grasses have a lower light saturation point and higher efficiency in colder temperatures (Brown 1982, Gardner et al. 2003), whereas the growth rate of C4 grasses decreases under shade (Pearcy and Ehleringer 1984, Kephart et al. 1992). Higher C3 abundance under trees has been reported in other mixed tree-grass systems, for example in North America (Scholes and Archer 1997, Sharrow et al. 1999), South America (Del Pilar Clavijo et al. 2005, Nordenstahl et al. 2011) and South Africa (Cowling 1983). Our findings are consistent with reports of facilitation of $\mathrm{C} 3$ grass species as a result of abiotic stress amelioration by shrubs in 
eastern Uruguay (Fernández et al. 2014). Because the abundance of C3 grasses can increase under cattle exclusion (Rodríguez et al. 2003, Altesor et al. 2005), one could speculate that the positive effect of trees on $\mathrm{C} 3$ grasses could also be partly explained by a reduction in grazing pressure under the tree canopies. Our study sites are grazed by cattle and our sampled plots were accessible to them, which makes this lower grazing hypothesis less likely. Tree shade had opposite effects on $\mathrm{C} 4$ grasses. The dominant C4 grass Paspalum was significantly less abundant under trees. Interestingly, subordinate $\mathrm{C} 4$ genera, forbs and graminoids increased under the tree shade

Plant nitrogen content was higher under the tree canopy than in open grasslands. This boost in nitrogen results from both, an overall increase in $\mathrm{N}$ content of understory grasses, as well as a shift in species composition towards a higher abundance of $\mathrm{C} 3$ species with higher $\mathrm{N}$ content. Leguminous trees, such as Acacia caven, are nitrogen fixers that can increase plant $\mathrm{N}$ through either soil improvement or direct below-ground N transfer (Daudin and Sierra 2008, Gargaglione et al. 2014).

Our results suggest that, by favoring C3 grasses, trees scattered through the grassland could directly improve the abundance of livestock forage during the colder seasons, with potential positive impacts on livestock productivity. Low production and low quality of pastures are key constraints of livestock productivity on natural grasslands of Uruguay during the colder seasons (Berretta 2001). In fact, winter is the critical season for livestock productivity since winter forage production usually determines maximum cattle loads (Nordenstahl et al. 2011). The increase of $\mathrm{C} 3$ grasses and the overall higher $\mathrm{N}$ content of the herbaceous plants growing in the understory of trees can therefore improve the provisioning of forage during the most limiting season.

Besides tree canopy, we identified the distance from the forest edge determined as an important environmental gradient structuring the herbaceous community. The distance to the 
forest edge is a complex gradient of environmental factors that combines decreasing elevation, more frequent flooding, differences in soil properties, higher tree density and an overall cooler and moister microclimate (Fig. 4.2). This gradient may be capturing some of the environmental factors, such as soil and micro-topographic features, which are known to determine small-scale variability in community composition in the region (Lezama et al. 2006).

The effect of trees in facilitating understory plants has been particularly well documented in stressful environments such as arid or semi-arid savannas (Dohn et al. 2013) in accordance with the Stress Gradient Hypothesis (SGH). However the results in wetter environments, such as our study region, are less clear (Rivest et al. 2013).Our results contribute to the emerging view that positive interactions may be more common in moist habitats than initially thought (Holmgren and Scheffer 2010). Fully understanding the implications of facilitation in this system may require assessing the role of trees during several years. As we showed, tree shade can facilitate shade tolerant C3 plant species. These positive effects may be even stronger during moderate droughts that occur frequently in this region (Holmgren et al. 2012).

Understanding how trees modify the structure and composition of grasslands is highly relevant as changes in tree cover may occur abruptly with changes in climate conditions in subtropical and tropical regions (Hirota et al. 2011). The moister climate expected for southeastern South America in the future may favor tree cover expansion to savanna-like levels (Anadón et al. 2014a). Our results indicate that an expansion of sparse tree cover in certain areas may increase the abundance and quality of forage for livestock production in these mixed tree-grass systems, improving their ecosystem services and challenging the often negative perception people have of native trees in the rangelands of southeastern South America.

Clearly, these rangelands would be at risk if woody density progresses into dense stands that reduce the grass biomass necessary to feed the livestock or fuel the fires that maintain these 
open grassy biomes (Archibald et al. 2005, Bernardi et al. 2016b, Bond 2016). Further studies should assess the levels of tree cover that could maintain these positive effects to predict and manage the consequences of potential ecological transitions driven by global change.

\section{Conclusions}

Global trends of tree expansion into grasslands have raised concern due to potential decrease in rangeland productivity. Our study shows that, in the rangelands of subtropical South America trees can have positive effects on forage availability. We found an increase in $\mathrm{C} 3$ grass abundance and in total nitrogen in plant biomass in the herbaceous layer under trees, suggesting that trees can improve forage quality and abundance particularly during the colder seasons when grass productivity is limited.

\section{ACKNOWLEDGEMENTS}

We thank P. Maldini for his assistance in field sampling and species identification; C. Fosalba for conducting the plant nutrient analyses; A. Rossado and F. Haretche for species identification; M. Arim, F. Lezama, N. Mazzeo and V. Picasso for helpful discussions. We thank Lab. Suelos \& Lab. Nutricion Animal at F.Agro, UdelaR for facilitating the use of equipment, the Municipality of Durazno for accommodation and managers and landowners of the estancias around Durazno for facilitating our work on their lands. We thank two anonymous reviewers for constructive criticism. This research was partly supported by grants from the National Research and Innovation Agency (ANII) of Uruguay to RB, the Alberta Mennega Foundation to IJ and the Dutch KNAW to MH. 


\section{Appendix to Chapter $4-\mathbf{A . 4}$}

Supplementary Material to the paper Bernardi, R.E., De Jonge, I. \& Holmgren, M. "Trees improve forage quality and abundance in South American subtropical grasslands".

Includes

Table A.4.1. Linear Mixed Effect Models.

Table A.4.2. Genera and photosynthetic pathway present in plots.

Table A.4.3. Mean abundance for the most common grass genera.

Table A.4.4. Results of Redundancy Analysis (RDA). 
Table A.4.1. Results of the Linear Mixed Effects models

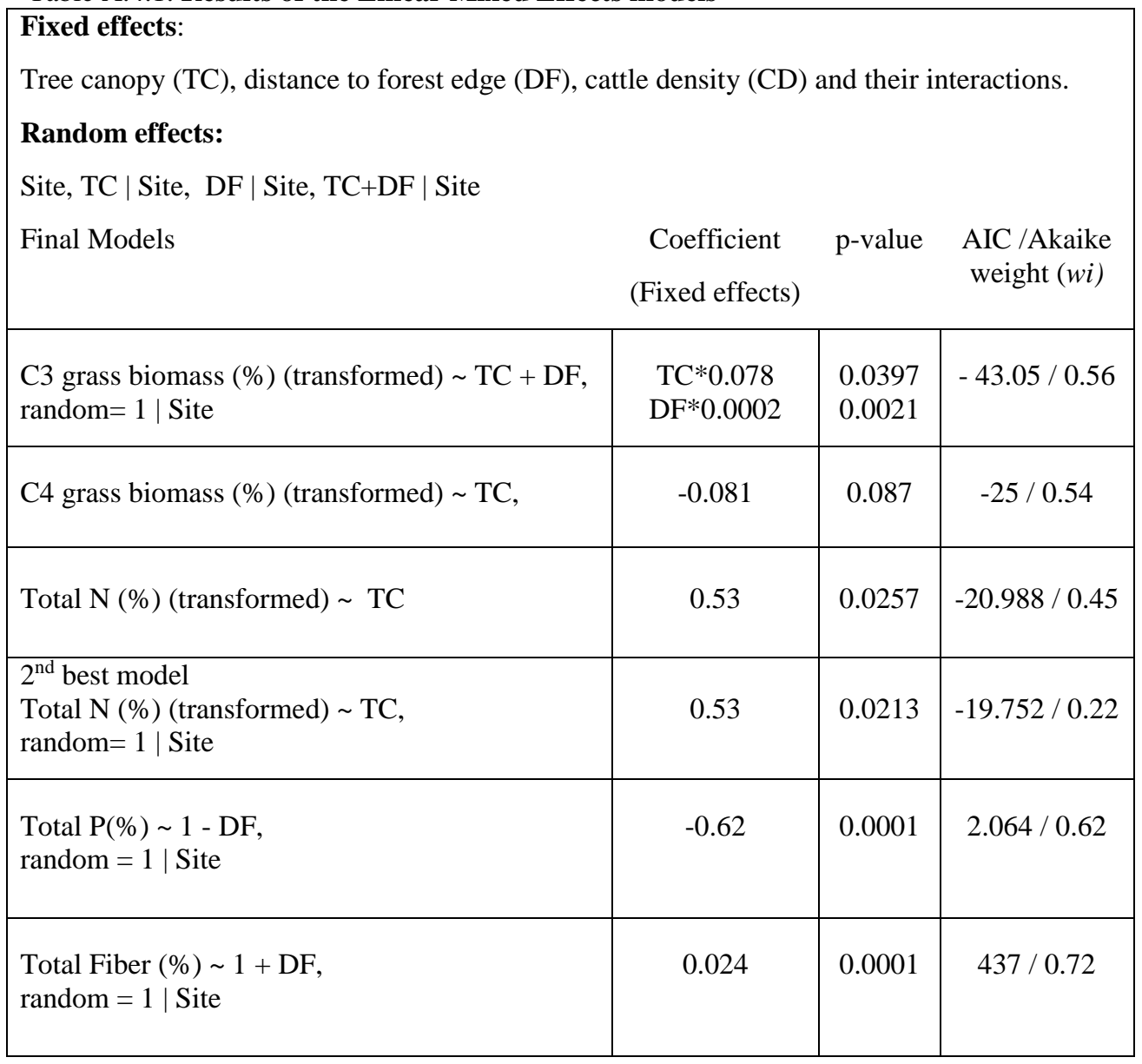


Table A.4.2. Genera and photosynthetic pathways found in sampling plots.

\begin{tabular}{|l|l|}
\hline \multicolumn{1}{|c|}{ Genera } & $\begin{array}{l}\text { Photosynthetic } \\
\text { pathway }\end{array}$ \\
\hline Agrostis & $\mathrm{C} 3$ \\
\hline Andropogon & $\mathrm{C} 4$ \\
\hline Aristida & $\mathrm{C} 4$ \\
\hline Axonopus & $\mathrm{C} 4$ \\
\hline Bothriocloa & $\mathrm{C} 4$ \\
\hline Briza & $\mathrm{C} 3 * *$ \\
\hline Calamagrostis & $\mathrm{C} 3 * *$ \\
\hline Chloris & $\mathrm{C} 4 * *$ \\
\hline Coleorachis & $\mathrm{C} 4$ \\
\hline Cynodon & $\mathrm{C} 4$ \\
\hline Danthonia & $\mathrm{C} 3$ \\
\hline Digitaria & $\mathrm{C} 4 * *$ \\
\hline Eleusine & $\mathrm{C} 4 * *$ \\
\hline Eragrostis & $\mathrm{C} 4$ \\
\hline Eustachys & $\mathrm{C} 4 * *$ \\
\hline Melica & $\mathrm{C} 3$ \\
\hline Panicum & $\mathrm{C} 4 *$ \\
\hline Paspalum & $\mathrm{C} 4$ \\
\hline Piptochaetum & $\mathrm{C} 3$ \\
\hline Schizaquirium & $\mathrm{C} 4$ \\
\hline Setaria & $\mathrm{C} 4$ \\
\hline Sorgasthrum & $\mathrm{C} 4 * *$ \\
\hline Sporobolus & $\mathrm{C} 4$ \\
\hline Stipa & $\mathrm{C} 3$ \\
\hline
\end{tabular}

* Panicum milioides is considered to have both $\mathrm{C} 4$ and $\mathrm{C} 3$ photosynthetic pathways. It was grouped as $\mathrm{C} 4$ given than summer is its growth and seeding season.

** Species present in less than $5 \%$ of the plots 
Table A.4.3: Mean abundance ( $\%$ basal cover $\pm \mathrm{SE}$ ) for the most common grass $\mathrm{C} 4$ and C3 genera outside and under tree canopy. Paired t-test values.

\begin{tabular}{|l|l|l|l|l|l|l|}
\hline \multirow{2}{*}{ Genus } & \multicolumn{2}{|c|}{ Outside } & \multicolumn{2}{c|}{ Under } & \multicolumn{2}{c|}{ Significance } \\
\cline { 2 - 7 } & Mean & SE & Mean & SE & t & p \\
\hline C4 & & & & & \\
Cynonopus & 4.0 & 2.0 & 8.2 & 4.61 & -1.42 & $0.16-\mathrm{ns}$ \\
Panicum & 4.5 & 3.8 & 5.3 & 4.57 & -0.9 & $0.37-\mathrm{ns}$ \\
Paspalum & 5.5 & 2.7 & 8.7 & 4.5 & -2.01 & 0.05 \\
C3 & 43.8 & 4.5 & 31.7 & 6.2 & 3.86 & $<0.0001$ \\
Piptochaetum & 3.4 & 2.0 & 3.0 & 1.8 & 0.29 & $0.77-\mathrm{ns}$ \\
Stipa & 2.8 & 1.4 & 6.2 & 2.6 & -2.5 & 0.017 \\
\hline
\end{tabular}


Table A.4.4. Results of Redundancy Analysis (RDA).

\begin{tabular}{|c|c|c|c|c|}
\hline $\begin{array}{l}\text { Redundancy Analysis } \\
\text { Partial variation is } 16.59 \text {. } \\
\text { Explanatory variables account for } 19.6\end{array}$ & $\%$ of vari & ation & & \\
\hline Statistic & Axis 1 & Axis 2 & Axis 3 & Axis 4 \\
\hline Eigenvalues & 0.058 & 0.050 & 0.024 & 0.0023 \\
\hline Explained variation (cumulative) & 8.44 & 15.7 & 19.25 & 19.58 \\
\hline Pseudo-canonical correlation & 0.60 & 0.58 & 0.51 & 0.32 \\
\hline Explained fitted variation (cumulative) & 43.1 & 80.18 & 98.31 & 100 \\
\hline
\end{tabular}




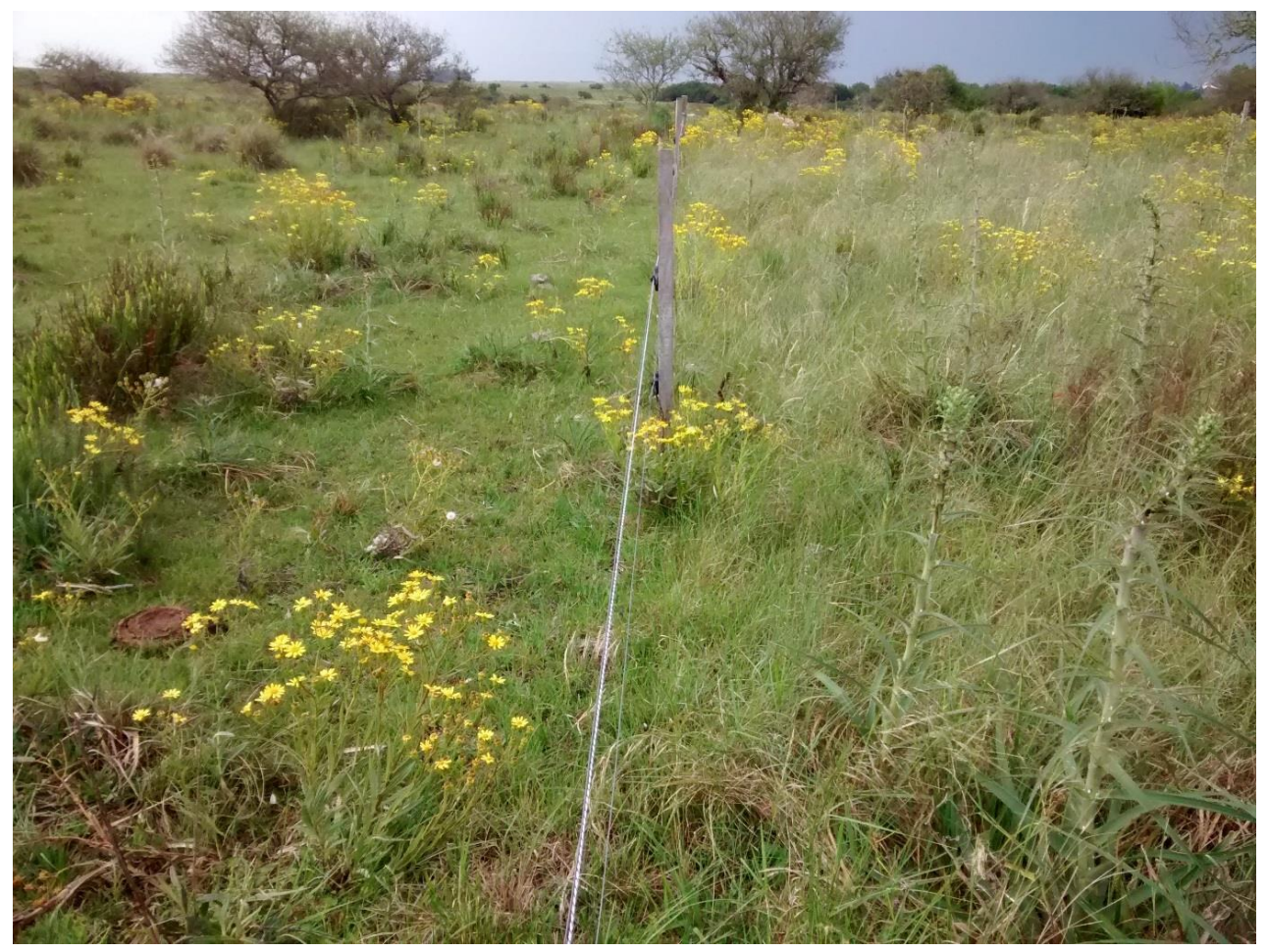

Photograph: Rafael Bernardi

\section{Chapter 5}

\section{Livestock suppresses fire across the global tropics}

Rafael E. Bernardi, Milena Holmgren, Arie Staal, Chi Xu, Marten Scheffer.

(Submitted) 


\section{Abstract}

\section{Aim}

Livestock grazing is the largest human land use and the main driver of the conversion of tropical forests into grasslands. Livestock is known to affect vegetation directly but also indirectly through interactions with fire. While many elements of the complex interplay of mechanisms have been scrutinized, a systematic analysis of the overall effects of livestock on tropical ecosystem structure is lacking.

\section{Location}

Global tropics and subtropics $\left(15^{\circ} \mathrm{N}-35^{\circ} \mathrm{S}\right)$.

\section{Methods}

We analyzed remote sensing and ground data on vegetation height and cover, climate, fire history and livestock. We used spatial regression models and structural equation models to analyze the effects of livestock on fire regimes and vegetation structure.

\section{Results}

High livestock densities are associated to lower fire frequency and a higher cover of shrubs and dwarf trees across the global tropics. This effect is particularly significant in South America.

\section{Main Conclusions}

Our findings suggest that grazing reduces fire incidence through grass fuel consumption and maintains sparse tree cover while favoring low-statured woody plants in regions where forests could potentially grow. In South America, the effects of livestock may explain the existence of wet savannas with low fire frequency. Our results imply that livestock is a strong modifier of the relationship between tropical vegetation structure and climate. 


\section{Introduction}

Livestock grazes approximately one third of the global land surface and about half of the world's savannas and grasslands. In the tropics, livestock ranching extends over 32 million $\mathrm{km}^{2}$, twice the area covered by tropical moist forest (Asner et al. 2004, Thornton and Herrero 2010). Despite this enormous extent, the effects of livestock management on vegetation structure have never been assessed globally. Livestock effects are hotly debated because regional- and site-level studies have described both increases and decreases in woody cover expansion with contrasting consequences for the long-term provision of ecosystem services. Grazing can promote woody encroachment (Scholes and Archer 1997, Roques et al. 2001, Eldridge et al. 2011) by shifting competitive interactions between herbaceous and woody plants in favor of the latter (Walter 1971, Belsky and Blumenthal 1997) or by reducing grasses that fuel fires (Belsky and Blumenthal 1997, Scholes and Archer 1997). On the other hand, livestock can limit woody expansion through direct browsing and trampling on tree seedlings and saplings (Huntly 1991, Prins and van der Jeugd 1993, Holmgren et al. 2006a, Chaturvedi et al. 2012, Bernardi et al. 2016b).

The effects of grazing on fire dynamics may be particularly important for shaping the structure and functioning of tropical and subtropical terrestrial ecosystems. Fire may maintain open grasslands and savannas because trees are more susceptible than grasses to recurrent fire events. Grasses regrow fast after burning and thereby provide fuel to burn again, creating a grass-fire positive feedback that suppresses tree cover (Archibald et al. 2009, Hoffmann et al. 2012). This grass-fire feedback has been proposed as a main mechanism explaining the bimodality of tropical tree cover (Hirota et al. 2011, Staver et al. 2011) and canopy height (Xu et al. 2016) which is suggestive of tropical forest and savanna being alternative stable states separated by tipping points (Scheffer et al. 2009, Hirota et al. 2011). By consuming grass 
biomass, which serves as fuel for fires, grazing can mediate this fire feedback affecting vegetation.

Here we aim to evaluate the overall effect of the complex mix of mechanisms through which livestock affects fire and woody vegetation along climatic gradients across the tropics.

\section{Methods}

\section{Global databases}

We generated a $0.1^{\circ} \times 0.1^{\circ}$ grid system over the global tropics and subtropics (latitudes between $15^{\circ} \mathrm{N}$ and $35^{\circ} \mathrm{S}$, Fig 5.1) yielding approximately 500,000 grid cells. For each grid cell, we collected estimates of livestock density, fire frequency, tree cover, shrub cover, mean annual precipitation, and precipitation seasonality. Livestock density was obtained from the FAO Gridded Livestock of the World modeled dataset at $1 \mathrm{~km}$ resolution (Robinson et al. 2014) and expressed in 250-kg-equivalent animal units called Tropical Livestock Units (TLU) using a scale of 0.7 for cattle, 0.5 for buffaloes and 0.1 for goats and sheep (FAO 1999). To avoid potential effects of pseudoreplication of nested environmental variables that are included in the FAO model, we averaged the model values for each administrative division to obtain the original data from national reports, or averaged model estimates for those divisions with missing data. Directly using the modeled data did not yield significant differences. We differentiated between high and low livestock densities, defined as being above and below the average value of TLU across the pantropical regions (7 TLU km$^{-2}$ ). 

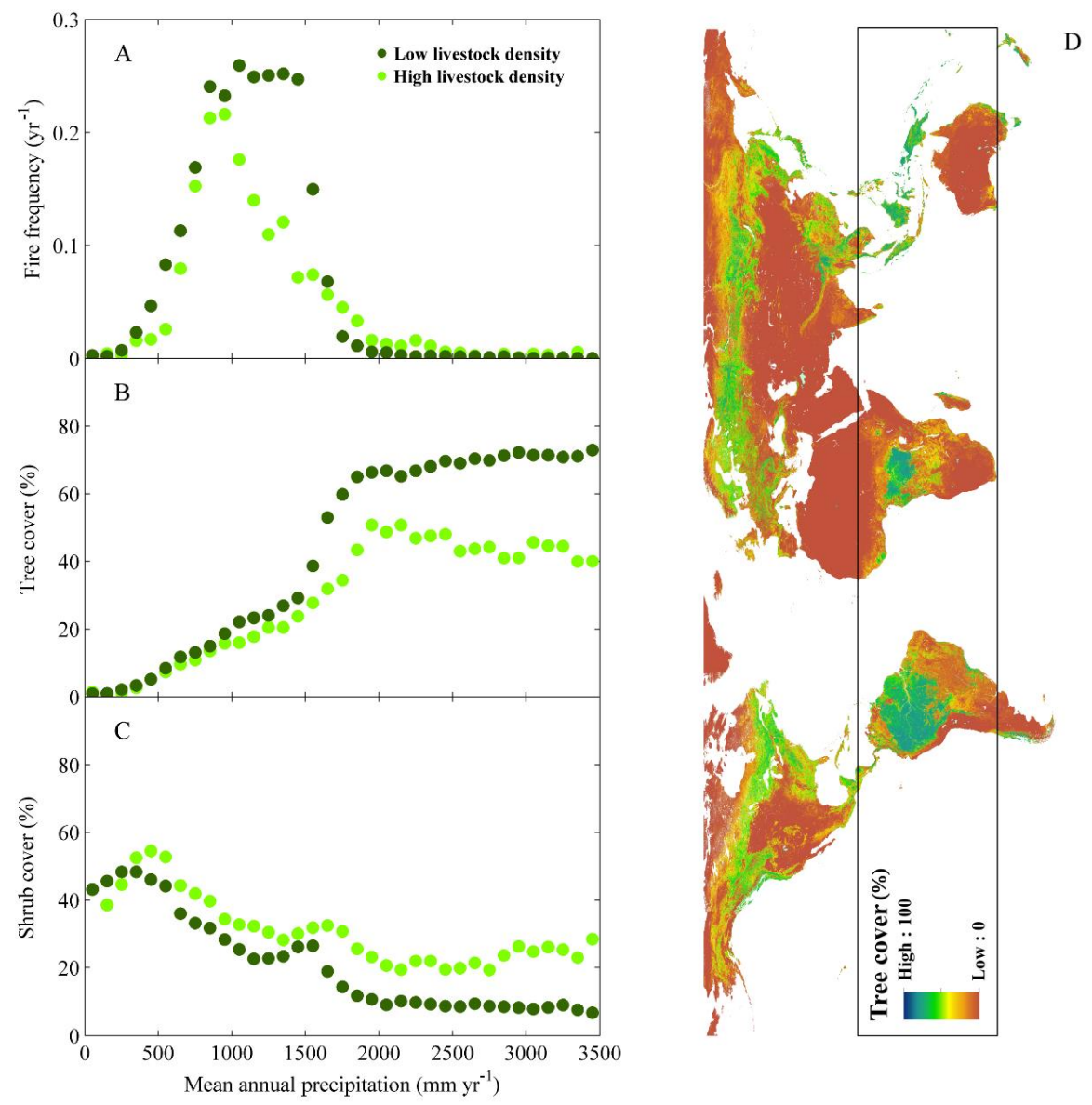

Figure 5.1. Differences in fire frequency, tree and shrub cover associated to tropical livestock density. A) Mean fire frequency averaged in $100 \mathrm{~mm}$ mean annual precipitation bins for sites with above-average (TLU $\geq 7$ units $\mathrm{km}^{-2}$, light dots) vs. below-average (TLU $<7$ units $\mathrm{km}^{-2}$, dark dots) livestock densities. B) Tree cover (\%). C) Cover of shrubs and dwarf trees (\%). D) Region of analysis. 
Fire frequency was derived by calculating burned frequency (burns per year) from the standard MODIS burned area product MCD45 (Roy et al. 2008) for the years 2002-2010. We considered the start of each year in April and the end in March the next year, coinciding with the annual global minimum fire activity during March-April (Giglio et al. 2013), to generate annual composite burned area maps.

Tree cover data were extracted from the MODIS Vegetation Continuous Field (VCF) Collection 5 dataset for the year 2009 (DiMiceli et al. 2011). MODIS infers tree cover as the woody cover higher than 5 meter tall. This coincides with standard life forms definitions (Pérez-Harguindeguy et al. 2013). To estimate lower woody cover (i.e. dwarf trees and shrubs), we used a remote-sensing dataset of global vegetation height (Los et al. 2012). This dataset assembled available LiDAR measurements (footprints) collected by the Geoscience Laser Altimeter System (GLAS) on the Ice, Cloud and land Elevation Satellite (ICESat) during 20032009 to retrieve the vegetation height distribution between $0-70 \mathrm{~m}$ in a $0.5 \mathrm{~m}$ interval per $0.5^{\circ}$ $\times 0.5^{\circ}$ grid cell. We calculated lower woody cover as the percent of LiDAR footprints with vegetation height between 1-5 $\mathrm{m}$. We used an upper five meter threshold to account for all woody vegetation in our analyses, given the $5 \mathrm{~m}$ lower detection limit of MODIS VCF tree cover. The $5 \mathrm{~m}$ threshold is also supported by observed distributions of global height of shrubs vs. trees (Scheffer et al. 2014, Xu et al. 2016). We tested for the robustness of using a different canopy height range (0.5-1.5 $\mathrm{m}$ for the lower limit and 4-5 $\mathrm{m}$ upper limit) to define dwarf trees and shrubby vegetation but did not yield different results.

Climate data were obtained from the Climate Research Unit (CRU) database at $0.5^{\circ}$ resolution in the period 1951-2002 (Jones and Harris 2013). We used Markham's Seasonality Index (MSI) as an indicator of the concentration of precipitation within certain months of the year (Markham 1970). 
We excluded from all datasets areas that included croplands, water or bare ground, as defined as categories [11-30 and 190-230] in the 2005 European Space Agency (ESA) Globcover dataset at $300 \mathrm{~m}$ resolution. Analyses were done using ArcGIS 10.0 and R 3.2.3.

\section{Data analyses}

We used spatial generalized least squares (GLS) models to relate fire frequency to livestock density and rainfall patterns. We included MSI, MAP, and $\mathrm{MAP}^{2}$, the latter to account for the hump-shaped distribution of fire frequency with MAP (Lehmann et al. 2011, Pausas and Ribeiro 2013). We ran models for the global tropics and each continent separately (South America, Africa, and South Asia - Oceania). In each case, we used a random subsample of 1000 points. To approach normal distributions, the percentage tree and shrubby cover were arcsine-square-root transformed (Hirota et al. 2011). The GLS models had a spatial correlation structure in residuals (Zuur et al. 2009). We assessed five different spatial correlational structures: exponential, Gaussian, linear, rational quadratic and spherical (Zuur et al. 2009) based on the Akaike Information Criterion (AIC). Spatial autocorrelation was best accounted for by an exponential decay for all study regions. We found no strong multicollinearity among the explanatory variables as indicated by low variance inflation factors (VIF) for MAP (1.18), MSI (1.18) and livestock (1.0). The statistical Analyses were performed in R 3.2.3 with the packages car, gstat, MuMIn, MASS, nlme, psych. We assessed the goodness of fit of the models based on the log likelihood-ratio test with the function "r.squaredLR" of the package MuMIn.

To facilitate a comprehensive understanding on how the focal factors interact with each other, we developed a conceptual model based on the observed relationships between variables (Fig. 5.2). We constructed a piecewise structural equation model (SEM) to test this network of relationships using the piecewiseSEM package (Lefcheck 2016) in R 3.2.3. To reduce spatial 
dependency of our analysis we randomly selected 1000 points per run, and we bootstrapped with 1000 repetitions.

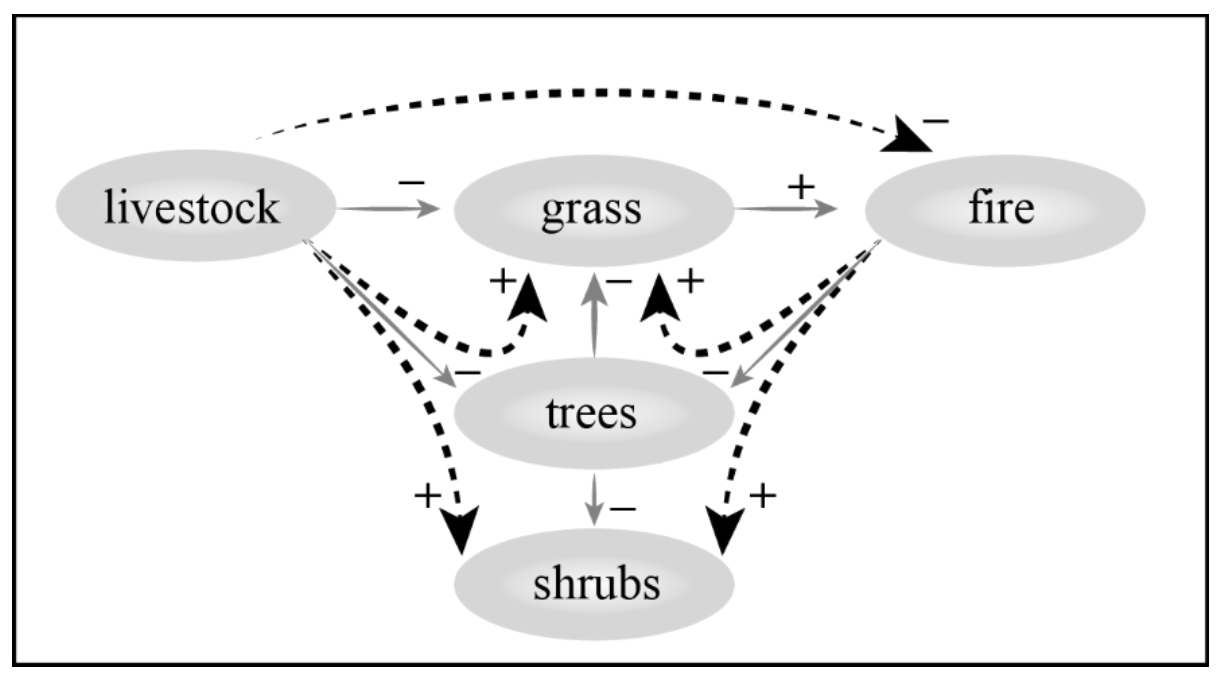

Figure 5.2. Conceptual model of relations between livestock, climate, grass cover, fire frequency and tree and shrub cover. Positive effects are indicated by pluses and negative effects by minuses, dashed lines indicate indirect effects. Livestock grazing reduces grass cover and thereby fuel for fire, favoring woody expansion; however, livestock grazing also limits tree growth, favoring shrubs and dwarf trees.

\section{Results}

Our analysis (see methods) shows that fire frequency across the global tropics decreases with livestock density (spatial GLS model; $p=0.005$ ). Sites with livestock density higher than the global tropical mean of $7 \mathrm{TLU} \mathrm{km} \mathrm{km}^{-2}$ have about half the fire frequency of sites with low livestock density (Fig. 5.1). Fire occurrence is also related to mean annual precipitation (MAP) and rainfall seasonality (MSI) (Table A.5.1). Fire frequency peaks at intermediate rainfall (MAP $\left.p=0.0016 ; \mathrm{MAP}^{2} p=0.0015\right)$ and with high rainfall seasonality $(p=0.0015)$. 
Across the whole precipitation gradient, sites with high livestock grazing had consistently lower tree cover and higher cover of small woody plants (Fig. 5.1B, C). Interestingly, a precipitation-dependent relationship between tree cover and livestock becomes apparent if we differentiate between regions with a MAP below and above $1600 \mathrm{~mm}$, a threshold where mean fire occurrence drops considerably (Fig. 5.1A). Above this value, high livestock density was associated to an increased likelihood of a savanna-like mode with $20 \%$ tree cover instead of closed-canopy forests ( $\geq 60 \%$ tree cover) (Fig. A.5.1). These savanna-like regions with high rainfall and livestock densities also have a relatively low fire frequency (Fig. A.5.2)

A piecewise structural equation model for the global tropics (Fig. A.5.3) suggests that fire frequency is positively affected by MAP and rainfall seasonality, and negatively by livestock density, while tree cover is positively affected by MAP and negatively affected by rainfall seasonality and livestock density. In contrast, cover of shrubs is negatively affected by MAP, tree cover, fire frequency and rainfall seasonality.

The strength of the relationships between fire, climate and livestock varies between continents. For South America, our spatial models show that fire occurrence is positively correlated to mean annual precipitation and also to seasonality in rainfall, while fire occurrence decreases with livestock density. For Africa we found the same relationships of fire occurrence with climate variables but no significant relationships with livestock density. For AsiaOceania, fire occurrence was only positively correlated to rainfall seasonality (Table A.5.1).

\section{Discussion}

Our results suggest that livestock reduces fire frequency across the global tropics (Fig. 5.1; Table A.5.1). This is in line with the view that grazing limits fire by reducing the availability 
of grass fuel (Belsky and Blumenthal 1997, Scholes and Archer 1997) and by the formation of grazing lawns acting as barriers for fire spread (Leonard et al. 2010, Hempson et al. 2015b).

Sites with high livestock densities have sparser tree cover (Fig. 5.1B) but a denser cover of low-statured woody plants (dwarf trees and shrubs) along the whole precipitation range in the three continents (Fig. 5.1B). Livestock may affect trees and shrubs in many ways, making it difficult to predict the net effect from individual mechanisms. Regenerating trees and shrubs may be facilitated by fire suppression (Belsky and Blumenthal 1997, Scholes and Archer 1997, Roques et al. 2001, Asner et al. 2009, D'Odorico et al. 2012). On the other hand, by browsing and trampling on young seedlings and saplings, livestock can also limit tree recruitment. Browsing at early growth stages also favors multi-stemmed, shorter sprouted trees with a bushy architecture (Huntly 1991, Bond and Midgley 2001, Holmgren 2002). Encroachment by woody vegetation is often controlled by rangers who seek to remove shrub thickets and cut regenerating trees to avoid canopy closure in managed pasture lands. Indeed, trees need time and favorable growth conditions to escape the control imposed by herbivory, fire and people (Holmgren et al. 2006a, Bond 2008, Scheffer et al. 2008, Hoffmann et al. 2012, Holmgren et al. 2013).

The apparent effects of livestock on fire, trees and shrubby vegetation have important implications for our interpretation of the distributions of forests and savannas. Remote-sensing studies suggest that savannas and forests can be alternative stable states (Hirota et al. 2011, Xu et al. 2016), maintained by a grass-fire feedback (Staver et al. 2011, Hoffmann et al. 2012, Murphy and Bowman 2012). The hump-shaped distribution of fire frequency (Lehmann et al. 2011, Pausas and Ribeiro 2013) drops at a MAP of approximately $1600 \mathrm{~mm}$ (Fig. 5.1B) where the probability of closed canopies increases (Hirota et al. 2011, Staal et al. 2016). Our analysis suggests that in these wet regions, livestock may maintain savannas by directly controlling tree recruitment. These sites will have lower fire frequency than expected due to fuel-grass removal 
by livestock (Fig. A.5.2). Thus, the high livestock densities in South America may help explaining the surprisingly fire-scarce savannas of that continent (Lehmann et al. 2011). The clear relationship between livestock and fire we find in South America is absent in Africa (Table A.5.1) which might be due to the unaccounted effect of wild herbivores in our analysis. Indeed, wild large herbivores, largely extinct in South America, can be a significant factor in shaping biomes in Africa (Prins and van der Jeugd 1993, Asner et al. 2009, Hempson et al. 2015a, Dantas et al. 2016).

In summary, our analysis suggests that in tropical regions where wild large herbivores are no longer dominant, livestock management may shape the structure of savannas and grasslands, reducing fire frequency, maintaining sparse tree cover and favoring the expansion of shrubs and dwarf trees. 


\section{Acknowledgments}

We thank Matías Arim, Bernardo Flores, Salvador Pueyo and Egbert van Nes for valuable insights. We also thank Stijn Hantson for sharing the fire frequency database. This research was partly supported by grants from the National Research and Innovation Agency (ANII) of Uruguay to RB, the Dutch KNAW to MH, SENSE Research School to AS and the National Natural Science Foundation of China (41271197) to CX. 


\section{Appendix to Chapter 5 - A.5}

Table A.5.1. Statistical results. Fire frequency and explanatory drivers.

Figure A.5.1. Frequency distributions of tree cover.

Figure A.5.2 Fire frequency as a function of tree cover.

Figure A.5.3. Piecewise Structural Equation Model. 
Table A.5.1. Statistical results. Fire frequency and explanatory drivers. Generalized least squares spatial models for fire frequency (arcsine square-root transformed). Explanatory variables were Mean Annual Precipitation (MAP), Mean Annual Precipitation squared (MAP2), Markham's Seasonality Index (MSI) and Livestock Density (LD).

\begin{tabular}{|c|c|c|c|c|}
\hline \multirow[t]{2}{*}{ Region } & \multicolumn{4}{|c|}{ Explanatory Variables: MAP, MAP', MSI, LD } \\
\hline & Best model & Predictors & Estimate & $P$ value \\
\hline Global tropics & $f$ (MAP, MAP' ${ }^{2}$, LD, MSI) & $\begin{array}{l}\text { MAP } \\
\text { MAP }^{2} \\
\text { LD } \\
\text { MSI }\end{array}$ & $\begin{array}{l}2.03 \cdot 10^{-4} \\
6.44 \cdot 10^{-8} \\
2.22 \cdot 10^{-3} \\
3.16 \cdot 10^{-3}\end{array}$ & $\begin{array}{l}0.002 \\
0.002 \\
0.005 \\
0.002\end{array}$ \\
\hline South America & $f$ (MAP, MAP' ${ }^{2}$, LD, MSI) & $\begin{array}{l}\text { MAP } \\
\text { MAP }^{2} \\
\text { LD } \\
\text { MSI }\end{array}$ & $\begin{array}{r}2.57 \cdot 10^{-4} \\
7.00 \cdot 10^{-4} \\
-2.94 \cdot 10^{-3} \\
4.13 \cdot 10^{-3}\end{array}$ & $\begin{array}{l}<0.001 \\
<0.001 \\
<0.001 \\
<0.001\end{array}$ \\
\hline Africa & $f$ (MAP, MAP'2, MSI) & $\begin{array}{l}\text { MAP } \\
\text { MAP }^{2} \\
\text { MSI }\end{array}$ & $\begin{array}{c}5.78 \cdot 10^{-4} \\
-2.10 \cdot 10^{-7} \\
3.61 \cdot 10^{-3} \\
\end{array}$ & $\begin{array}{r}<0.001 \\
<0.001 \\
0.019 \\
\end{array}$ \\
\hline Asia-Oceania & $f$ (MSI) & MSI & $4.17 \cdot 10^{-3}$ & $<0.001$ \\
\hline
\end{tabular}


Figure A.5.1. Frequency distributions of tree cover for dry (MAP $<1600 \mathrm{~mm}$ ) and wet (MAP > 1600 $\mathrm{mm}$ ) regions and below and above-average livestock density ( 7 Tropical Livestock Units $\mathrm{km}^{-2}$ ). A) Dry sites, low livestock density. B) Wet sites, low livestock density. C) Dry sites, high livestock density. D) Wet sites, high livestock density.

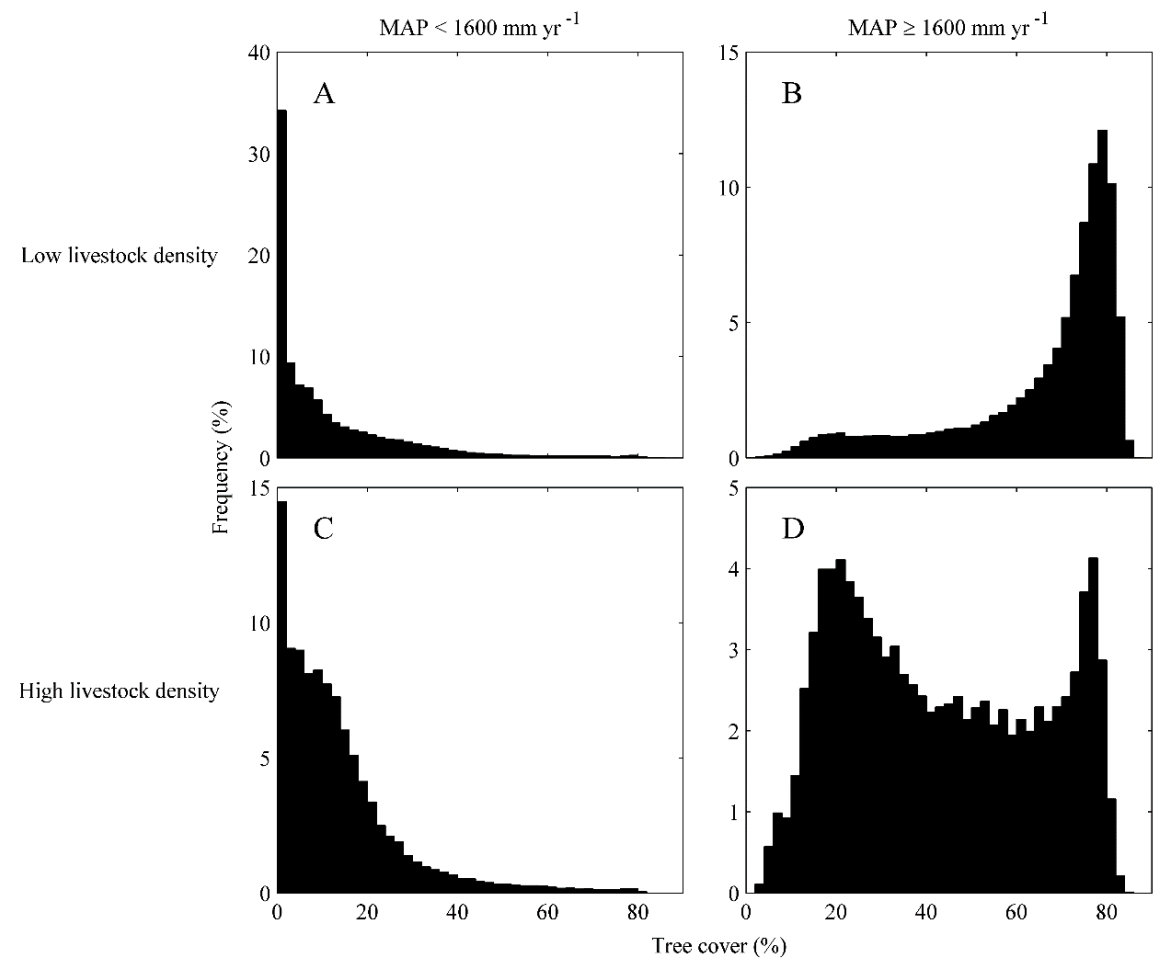


Figure A.5.2 Fire frequency as a function of tree cover. Fire frequency in high (light dots) and low (light dots) livestock densities for A) MAP below $1600 \mathrm{~mm}, \mathrm{~B}$ ) MAP > $1600 \mathrm{~mm}$.

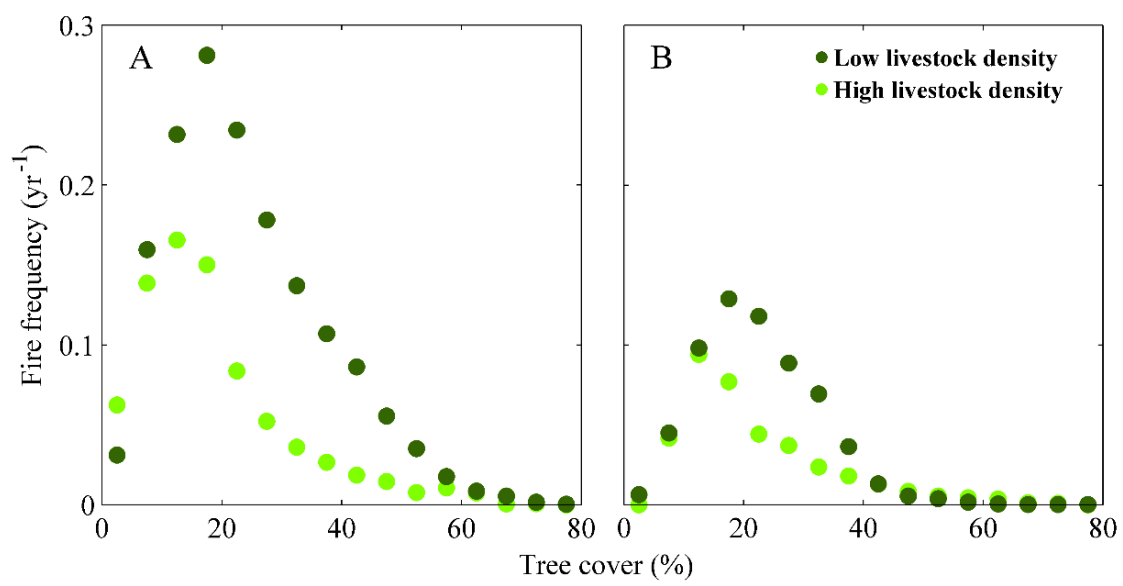


Figure A.5.3. Piecewise Structural Equation Model. Positive relationships in blue, negative in red. All tested relationships have $p$ values $<0.05$. Numbers indicate coefficient estimates of relationships. The light blue boxes indicate climatic variables (MAP, mean annual precipitation; MAP ${ }^{2}$, quadratic term of MAP; MSI, Markham's Precipitation Seasonality Index), the green boxes represent ecosystem variables (Livestock, livestock density; Fire, fire occurrence; Trees, tree cover; Shrubs, cover of shrubs and dwarf trees). $R^{2} \mathrm{~s}$ for component models are shown in the boxes of response variables. The Fire model is fitted using generalized linear model with Poisson distribution, the Trees and Shrubs models are fitted using ordinary least square models.

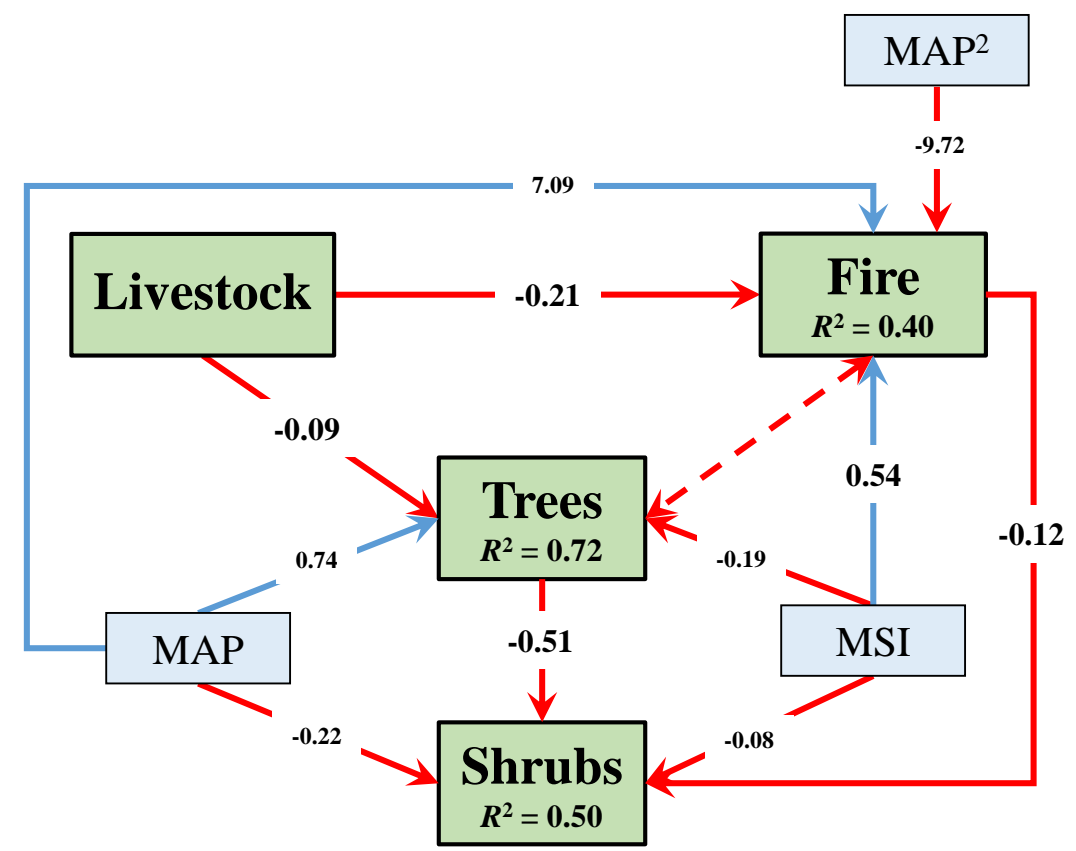




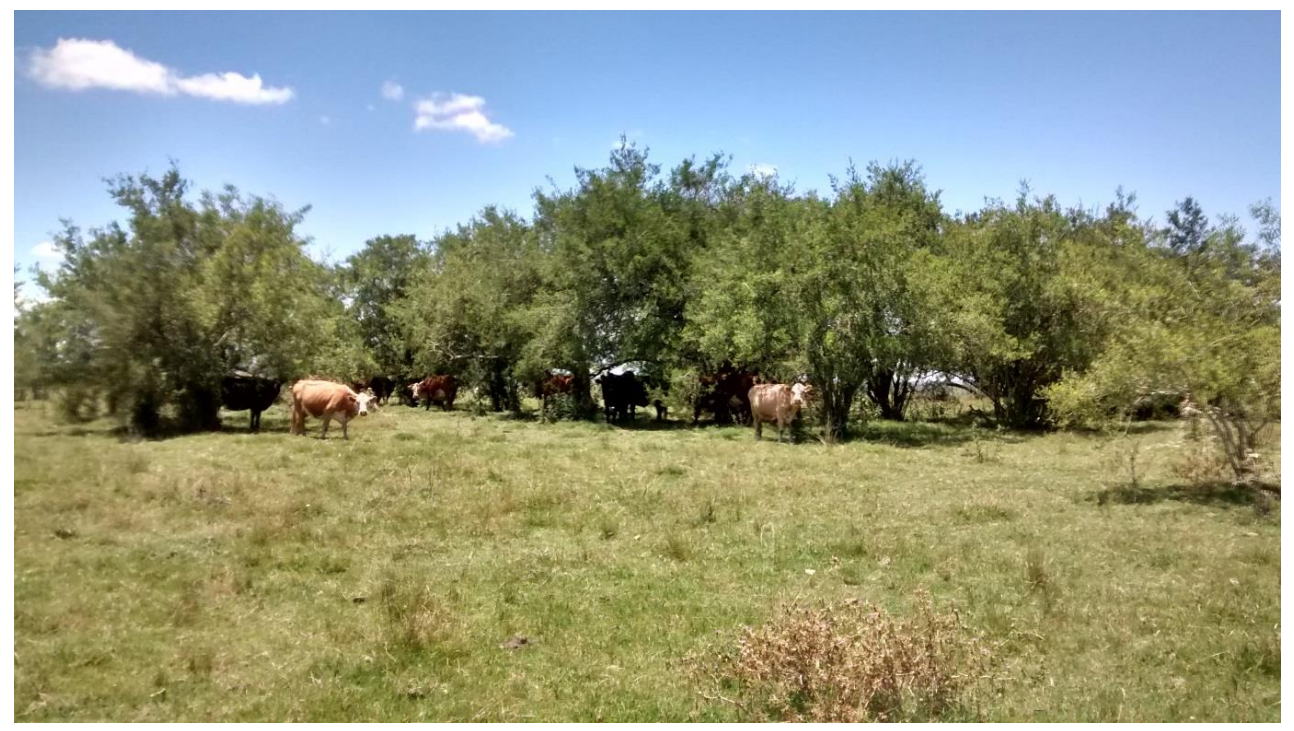

Photograph: Rafael Bernardi

\section{Chapter 6}

\section{Synthesis}


Looking at the extensive grassland landscapes of Uruguay, in subtropical South America, one cannot avoid having the intriguing feeling that something is missing. The same impression led Darwin, during the Voyage of the Beagle, to write about the "remarkable" scarcity of trees despite abundant precipitation in the green, smoothly undulated terrain. Understanding the distribution of plant communities is indeed complex, and what explains forests, savannas and grasslands across the world is still a highly debated issue.

In this thesis, I analyzed the determinants of tree cover distribution and the factors that may explain tree cover changes in mixed tree-grass systems across the tropics and subtropics. I combined different methodological approaches designed to address some of the gaps in current theoretical frameworks and research (Chapter I). First (Chapter 2), I modeled current tree cover distribution at three scales in southeastern South America, with a focus on the Campos region of Uruguay and Southern Brazil (WWF “Uruguayan Savanna”) (Soriano 1992, Olson et al. 2001, Overbeck et al. 2007) aiming to assess the mechanisms behind tree cover changes in grassy biomes. This analysis allowed us to account for the scale-dependency of some of the most relevant mechanisms and to detect the variation of factors that would otherwise be missed. I found that fire and livestock play a key role in limiting tree cover in the region, and we detected a reduction in fire associated to higher livestock densities.

In Chapter 3, I analyzed potential drivers of forest-grassland transitions in Uruguay by looking at tree cover change over four decades and at the relationship with relevant socioecological variables. I found that, while forest cover has decreased in regions with high agricultural cover, expansion of forests in extensive rangelands was likely associated to a release of grazing pressure by a reduction in livestock densities, which is in line with our findings in Chapter 2. I found that medium-scale soil and topographic features were likely determinant of the predominant land uses that in turn affect tree cover change, and that changes in land use can trigger forest-grasslands transitions in the region. These results emphasize the 
strong coupling between ecosystem dynamics and human activities. This analysis also contributed to improve our understanding of the change dynamics at intermediate spatial scales, and to overcome any limitation that may arise from inferring the probability of forestgrasslands states based on one snapshot of current tree cover distribution.

In Chapter 4, the interaction between trees and grasses at the local level was studied through field observations to determine potential consequences of changes in tree cover. Results show that a moderate expansion of trees could improve forage quality and abundance, yielding benefits in terms of provisioning services and that plant facilitative interactions may prevail in mild (sub-humid) environments.

Finally, in Chapter 5 I tested the hypothesis that livestock has a significant role in shaping the world terrestrial biomes, aiming to generalize the findings of this research across tropical and subtropical regions. I found evidence of livestock indeed being a strong anthropogenic influence on these systems, by limiting fire frequencies and through direct effects on woody vegetation.

\section{A pantropical view: the effect of livestock on grass, fire and trees}

The results presented in this thesis suggest that precipitation, fire and herbivory are the main determinants of tree cover in non-cultivated areas across the tropics and subtropics. In particular livestock appears to have a significant effect on vegetation in South America, where it is the dominant herbivore. The effects of livestock may be explained by direct top-down effects but also in part by a reduction of fire frequencies due to fuel-grass consumption.

A conceptual diagram of the interactions between livestock, fire, precipitation and tree and shrub cover is presented in Fig. 5.2. Livestock limits tree cover through browsing and trampling on young trees, maintaining a low tree cover beyond what would be expected from precipitation patterns. Livestock also consistently reduces fire frequency in the tropics and 
subtropics worldwide. Areas with below-average density of livestock have almost twice as high the fire frequency than areas with over-average livestock density. This causes deep ecological effects as it enables the persistence of short-statured woody vegetation (shrubs and dwarf trees), which are also promoted by browsing at early stages (Huntly 1991, Bond and Midgley 2001, Holmgren 2002).

These findings are important since a shift from trees to shrubby vegetation could partially explain patters of shrub encroachment into grasslands observed throughout the world (Belsky and Blumenthal 1997, Scholes and Archer 1997, Roques et al. 2001, Asner et al. 2009, D'Odorico et al. 2012). The role of livestock in shaping tree cover is particularly relevant in South America, where the use of grassy biomes for extensive livestock production may maintain savannas and grasslands with low tree cover but relatively high precipitation levels and low fire frequencies (Lehmann et al. 2011). This may be the case of the Campos grasslands in South America (Uruguayan Savanna Ecoregion) that were particularly studied in this thesis.

\section{Subtropical grasslands of South America: Old-growth and anthropogenic}

New debates about afforestation of grasslands for carbon sequestration, and concerns about impacts of woody encroachment on livestock production, highlight the need to understand the resilience of these grasslands in the face of environmental and land use changes (Overbeck et al. 2007, Bond and Parr 2010, Anadón et al. 2014b). As we have seen in this thesis, this requires assessing the role of climate and disturbances in shaping tree cover, and the effect of land use regimes in affecting the resilience of this ecoregion.

The climatic origins of the Campos grasslands have been well established. Palaeorecords suggest that the regional climate of southeastern South America was characterized by long dry periods, resulting in old-growth grasslands with high biodiversity of grasses (Sala 2001, Iriarte 2006, Overbeck et al. 2007, Piovano et al. 2009, Puerto et al. 2013, 
Veldman et al. 2015). The old-growth grasslands of southeastern South America persisted during long periods of dry climate and may have been maintained by grazing of large native herbivores (Barnosky et al. 2016, Doughty et al. 2016). More recently, studies for Southern Brazil suggest that the loss of large herbivores co-occurred with an increase in fire frequency, at the times when human populations expanded in the region $(\sim 8.000$ years B.P.) (Behling et al. 2007, Blanco et al. 2014). This suggests that humans may have strongly influenced the occurrence and magnitude of disturbance regimes for a very long period. During the last centuries, the expansion of livestock and agriculture has become a main determinant of changes in tree cover. Impacts have included cutting trees to use in fences and buildings and as a source of energy, although the magnitude and extent of the deforestation has not been well established (Gautreau 2010, Rodriguez-Pontes et al. 2016).

This thesis (Chapter 2) provides new evidence suggesting that tree cover in subtropical South America increases with precipitation and is limited by both cattle grazing and fire occurrence. We found that in the Campos sub-region forests are associated mostly to watercourses, which may have acted as a refuge during drier times, and that livestock is probably preventing forest expansion into grasslands. Current fire frequency, however, is very low (Di Bella et al. 2006), which may be a consequence of heavy grazing. Cattle, followed by sheep, are the main herbivores consuming grass and other plant biomass in southeastern South America, and they have likely affected fire dynamics since their initial introduction in the XVI century. Our results suggest that livestock grazing constitutes a strong anthropogenic determinant of tree-grass transitions in southeastern South America, where livestock is among the highest in the continent. The main relationships between tree cover, climate, fire frequency and livestock in the grasslands of subtropical South America (Chapter 2) are summarized in a conceptual model (Fig. 6.1). 


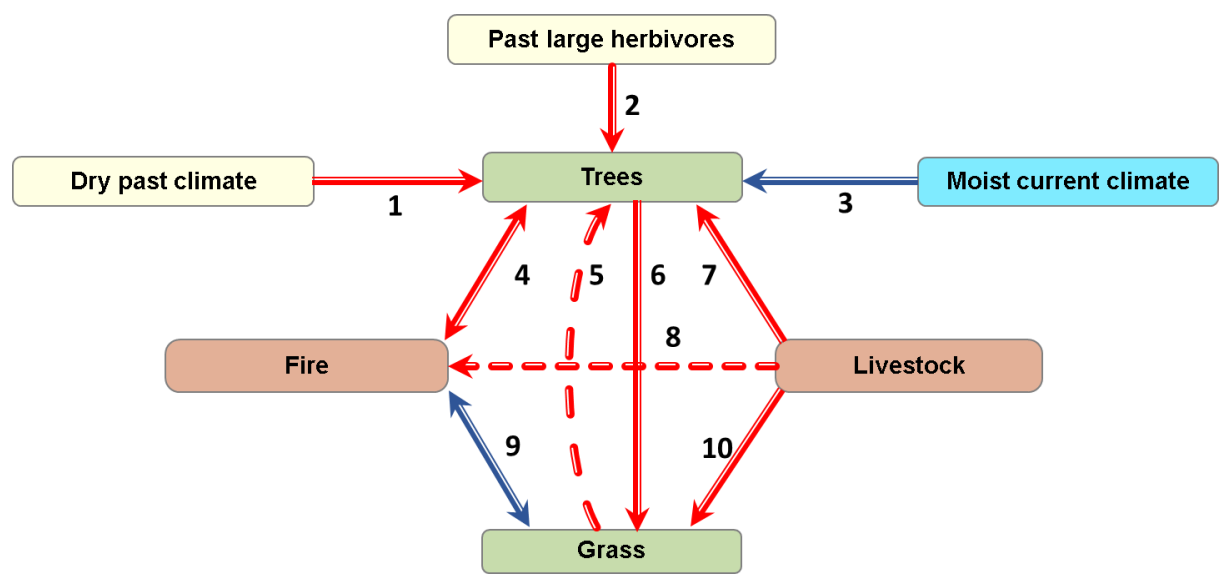

Figure 6.1. Conceptual model of relations between precipitation, herbivory, fire, livestock, and grass and tree cover in the grasslands of subtropical South America. Positive effects are indicated by blue arrows and negative effects by red arrows, dashed lines indicate significant indirect effects. In a nutshell: Past dry climate (1) (Piovano et al. 2009) and large herbivores (2) (Barnosky et al. 2016, Doughty et al. 2016) have limited tree cover, which could expand under present greater rainfall regime (3)(Gautreau 2010, Hirota et al. 2011, Anadón et al. 2014a). Livestock consumes grass (10) and thereby eliminates the fuel for fire $(8,9)$ (Chapters $2 \& 5)$, favoring woody expansion $(4,5)$ (Pillar and Quadros 1997, Blanco et al. 2014) which could in turn limit grasses (5); however, livestock grazing (at early stages of trees) also limits tree growth (7) (Chapter 2).

\section{Forest-grassland transitions in coupled socio-ecologic systems}

The previous findings imply that land use changes can result in significant changes in the trends of forest-grassland transitions. In Chapter 3, I show that forest change in the Campos of Uruguay is associated to climate and land use. Results suggest that forest cover likely decreased as a result of agricultural expansion, which is consistent with the well-known role of agriculture as a main cause of tree cover loss. Forest cover has, in contrast, increased in some regions with 
low agricultural cover where livestock densities have decreased. These changes were preceded by a widespread reduction in sheep stock as a result of a drop of international prices (Montossi et al. 2013). Forest gain occurred mostly in hills with rocky soils where sheep were not replaced by cattle.

Potential increases in tree cover such as the one found in Chapter 3 may raise concerns due to productivity loss in rangelands. However, the effects of trees in these grasslands have not been systematically assessed. Chapter 4 sought, therefore, to understand potential impacts of tree expansion in this ecosystem.

\section{Is tree expansion threatening old-growth rangelands?}

I found that isolated trees in subtropical rangelands can facilitate the growth and increase the nitrogen content of herbaceous biomass, and increase the abundance of C3 winter species within the herbaceous layer. This latter effect can contribute to an improved forage quality along the year, particularly in the winter season, when grass productivity reaches its annual low (Ode et al. 1980, Nordenstahl et al. 2011). Therefore, a potential expansion of trees into rangelands can have positive effects for livestock productivity, provided that tree cover is kept below the point where light limitation reduces grass growth. Trees can also facilitate shadetolerant $\mathrm{C} 3$ grasses in a context of increased extreme events under climate change, possibly contributing to the resilience of these mixed $\mathrm{C} 3-\mathrm{C} 4$ grasslands

The Stress-Gradient Hypothesis (SGH) (Bertness and Callaway 1994) postulates that the effects of trees on grasses tend to be positive in stressful environments but detrimental in more benign conditions, where competition may prevail over facilitation (Gómez-Aparicio et al. 2008, Dohn et al. 2013). The analysis of the impacts of isolated trees on grasses of central Uruguay in this thesis (Chapter 4) is in line with suggestions that these positive interactions in 
mild environments may be more frequent than previously thought (Holmgren and Scheffer 2010, Holmgren et al. 2012).

\section{Conclusions and future lines of research}

As we cross the thresholds to uncertain planetary conditions, integrating human activities into the ecological puzzles that may define our future is pressing. This thesis highlights the relevance of long-term anthropogenic effects in shaping today's ecosystems. Further studies may assess how livestock, and its effects on fire regimes, can affect the structure, spatial configuration and aggregation of trees in grasslands, and their potential ecological consequences. Follow-up work will also be needed to assess which tree cover distribution may maximize the system resilience in the face of climatic fluctuations and contribute the most to increased ecosystem services. The findings of this thesis support the seemingly contradictory idea that a transition from open grasslands to a savanna state in certain areas of subtropical South America can have positive effects on the environmental services of these rangelands. It is my hope that these results will contribute to balance the -currently mostly negativeperceptions of the effects of tree expansion into grasslands. 


\section{References}

Altesor, A., M. Oesterheld, E. Leoni, F. Lezama, and C. Rodríguez. 2005. Effect of grazing on community structure and productivity of a Uruguayan grassland. Plant Ecology 179:8391.

Altesor, A., G. Piñeiro, F. Lezama, R. B. Jackson, M. Sarasola, and J. M. Paruelo. 2006. Ecosystem changes associated with grazing in subhumid South American grasslands. Journal of Vegetation Science 17:323-332.

Anadón, J. D., O. E. Sala, and F. T. Maestre. 2014a. Climate change will increase savannas at the expense of forests and treeless vegetation in tropical and subtropical Americas. Journal of Ecology 102:1363-1373.

Anadón, J. D., O. E. Sala, B. L. Turner, and E. M. Bennett. 2014b. Effect of woody-plant encroachment on livestock production in North and South America. Proceedings of the National Academy of Sciences 111:12948-12953.

Archibald, S., W. J. Bond, W. D. Stock, and D. H. K. Fairbanks. 2005. Shaping the landscape: fire-grazer interactions in an African savanna. Ecological Applications 15:96-109.

Archibald, S., D. P. Roy, B. W. Van Wilgen, and R. J. Scholes. 2009. What limits fire? An examination of drivers of burnt area in Southern Africa. Global Change Biology 15:613-630.

Asner, G. P., A. J. Elmore, L. P. Olander, R. E. Martin, and A. T. Harris. 2004. Grazing systems, ecosystem responses, and global change. Annual Review of Environment and Resources 29:261-299.

Asner, G. P., S. R. Levick, T. Kennedy-Bowdoin, D. E. Knapp, R. Emerson, J. Jacobson, M. S. Colgan, and R. E. Martin. 2009. Large-scale impacts of herbivores on the structural 
diversity of African savannas. Proceedings of the National Academy of Sciences 106:4947-4952.

Baldi, G. and J. M. Paruelo. 2008. Land-use and land cover dynamics in South American temperate grasslands. Ecology \& Society 13 (2):6.

Barbehenn, R. V., Z. Chen, D. N. Karowe, and A. Spickard. 2004. C3 grasses have higher nutritional quality than $\mathrm{C} 4$ grasses under ambient and elevated atmospheric $\mathrm{CO} 2$. Global Change Biology 10:1565-1575.

Barlow, J., T. A. Gardner, A. C. Lees, L. Parry, and C. A. Peres. 2012. How pristine are tropical forests? An ecological perspective on the pre-Columbian human footprint in Amazonia and implications for contemporary conservation. Biological Conservation 151:45-49.

Barnosky, A. D., E. L. Lindsey, N. A. Villavicencio, E. Bostelmann, E. A. Hadly, J. Wanket, and C. R. Marshall. 2016. Variable impact of late-Quaternary megafaunal extinction in causing ecological state shifts in North and South America. Proceedings of the National Academy of Sciences 113:856-861.

Barral, M. P. and M. N. Oscar. 2012. Land-use planning based on ecosystem service assessment: a case study in the Southeast Pampas of Argentina. Agriculture, Ecosystems \& Environment 154:34-43.

Bartholomé, E. and A. Belward. 2005. GLC2000: a new approach to global land cover mapping from Earth observation data. International Journal of Remote Sensing 26:1959-1977.

Behling, H., V. D. Pillar, S. C. Müller, and G. E. Overbeck. 2007. Late-Holocene fire history in a forest-grassland mosaic in southern Brasil: implications for conservation. Applied Vegetation Science 10:81-90.

Belsky, A. and R. Amundson. 1992. Effects of trees on understorey vegetation and soils at forest-savanna boundaries in East Africa pages 353-367 in Furley, P., J. Ratter, and J. 
Proctor, editors. Nature and Dynamics of Forest-Savanna Boundaries. Chapman and Hall, London.

Belsky, A. J., S. M. Mwonga, R. G. Amundson, J. M. Duxbury, and A. R. Ali. 1993. Comparative effects of isolated trees on their undercanopy environments in high- and low-rainfall savannas. Journal of Applied Ecology 30:143-155.

Belsky, A. J. and D. M. Blumenthal. 1997. Effects of livestock grazing on stand dynamics and soils in upland forests of the Interior West. Conservation Biology 11:315-327.

Bernardi, R. E., I. K. de Jonge, and M. Holmgren. 2016a. Trees improve forage quality and abundance in South American subtropical grasslands. Agriculture, Ecosystems \& Environment 232:227-231.

Bernardi, R. E., M. Holmgren, M. Arim, and M. Scheffer. 2016b. Why are forests so scarce in subtropical South America? The shaping roles of climate, fire and livestock. Forest Ecology and Management 363:212-217.

Berretta, E., D. Risso, F. Montossi, G. Pigurina, G. Lemaire, J. Hodgson, A. d. Moraes, C. Nabinger, and P. Carvalho. 2000. Campos in Uruguay. Pages 377-394 in International Symposium on Grassland Ecophysiology and Grazing Ecology. CABI Publishing, Curitiba.

Berretta, E. J. 2001. Ecophysiology and management response of the subtropical grasslands of southern South America. 19th International Grassland Congress. FAO, Sao Pedro.

Bertness, M. D. and R. Callaway. 1994. Positive interactions in communities. Trends in Ecology \& Evolution 9:191-193.

Blanco, C. C., S. Scheiter, E. Sosinski, A. Fidelis, M. Anand, and V. D. Pillar. 2014. Feedbacks between vegetation and disturbance processes promote long-term persistence of forestgrassland mosaics in south Brazil. Ecological Modelling 291:224-232. 
Bond, W. J. and J. J. Midgley. 2001. Ecology of sprouting in woody plants: the persistence niche. Trends in Ecology \& Evolution 16:45-51.

Bond, W. J. 2005. Large parts of the world are brown or black: a different view on the 'Green World' hypothesis. Journal of Vegetation Science 16:261-266.

Bond, W. J. 2008. What limits trees in C4 grasslands and savannas? Annual Review of Ecology, Evolution, and Systematics 39:641-659.

Bond, W. J. and C. L. Parr. 2010. Beyond the forest edge: ecology, diversity and conservation of the grassy biomes. Biological Conservation 143:2395-2404.

Bond, W. J. 2016. Ancient grasslands at risk. Science 351:120-122.

Boschetti, L., D. Roy, and A. Hoffmann. 2009. MODIS Collection 5 Burned Area ProductMCD45. User's Guide. Ver 2. University of Maryland, College Park.

Braun-Blanquet, J. 1932. Plant Sociology. The Study of Plant Communities. McGraw-Hill, New York.

Brown, J. R. and J. Carter. 1998. Spatial and temporal patterns of exotic shrub invasion in an Australian tropical grassland. Landscape Ecology 13:93-102.

Brown, J. R. and S. Archer. 1999. Shrub invasion of grassland: recruitment is continuous and not regulated by herbaceous biomass or density. Ecology 80:2385-2396.

Brown, R. H. 1982. Response of terrestrial plants to light quality, light intensity, temperature, CO2, and O2. Pages 185-212 in A. Mitsui and C. C. Black, editors. Handbook of Biosolar Resources, Volume 1. Basic Principles. CRC Press, Florida.

Bucini, G. and N. P. Hanan. 2007. A continental-scale analysis of tree cover in African savannas. Global Ecology and Biogeography 16:593-605.

Burnham, K. P. and D. R. Anderson. 2004. Multimodel inference. Sociological Methods \& Research 33:261-304. 
Cai, X., Z. Wu, and J. Cheng. 2013. Using kernel density estimation to assess the spatial pattern of road density and its impact on landscape fragmentation. International Journal of Geographical Information Science 27:222-230.

Callaway, R. M. 2007. Positive Interactions and Interdependence in Plant Communities. Springer, New York.

Carrere, R. 2001. Monte Indígena: Mucho Más que un Conjunto de Árboles. Ediciones de Brecha, Montevideo.

Castaño, J. P., A. Giménez, M. Ceroni, J. Furest, and R. Aunchayna. 2011. Caracterización agroclimática del Uruguay 1980-2009. Serie Técnica INIA 193.

Cesa, A. and J. M. Paruelo. 2011. Changes in vegetation structure induced by domestic grazing in Patagonia (southern Argentina). Journal of Arid Environments 75:1129-1135.

Cingolani, A. M., M. V. Vaieretti, M. A. Giorgis, M. Poca, P. A. Tecco, and D. E. Gurvich. 2014. Can livestock grazing maintain landscape diversity and stability in an ecosystem that evolved with wild herbivores? Perspectives in Plant Ecology, Evolution and Systematics 16:143-153.

Cowling, R. M. 1983. The occurrence of C3 and C4 grasses in fynbos and allied shrublands in the South Eastern Cape, South Africa. Oecologia 58:121-127.

Cramer, W., A. Bondeau, F. I. Woodward, I. C. Prentice, R. A. Betts, V. Brovkin, P. M. Cox, V. Fisher, J. A. Foley, A. D. Friend, C. Kucharik, M. R. Lomas, N. Ramankutty, S. Sitch, B. Smith, A. White, and C. Young-Molling. 2001. Global response of terrestrial ecosystem structure and function to $\mathrm{CO} 2$ and climate change: results from six dynamic global vegetation models. Global Change Biology 7:357-373.

Chaneton, E. J., N. Mazía, W. B. Batista, A. G. Rolhauser, and C. M. Ghersa. 2012. Woody plant invasions in Pampa grasslands: a biogeographical and community assembly 
perspective. Pages 115-144 in R. W. Myster, editor. Ecotones between Forest and Grassland. Springer, New York.

Chapin III, F. S., E. S. Zavaleta, V. T. Eviner, R. L. Naylor, P. M. Vitousek, H. L. Reynolds, D. U. Hooper, S. Lavorel, O. E. Sala, S. E. Hobbie, M. C. Mack, and S. Diaz. 2000. Consequences of changing biodiversity. Nature 405:234-242.

Chapin III, F. S., G. P. Kofinas, C. Folke, and M. C. Chapin. 2009. Principles of Ecosystem Stewardship: Resilience-Based Natural Resource Management in a Changing World. Springer Science \& Business Media, New York.

Chaturvedi, R. K., A. S. Raghubanshi, and J. S. Singh. 2012. Effect of grazing and harvesting on diversity, recruitment and carbon accumulation of juvenile trees in tropical dry forests. Forest Ecology and Management 284:152-162.

D'Odorico, P., G. S. Okin, and B. T. Bestelmeyer. 2012. A synthetic review of feedbacks and drivers of shrub encroachment in arid grasslands. Ecohydrology 5:520-530.

Dantas, V. d. L., M. Hirota, R. S. Oliveira, and J. G. Pausas. 2016. Disturbance maintains alternative biome states. Ecology Letters 19:12-19.

Darwin, C. 1890. The Voyage of the Beagle. John Murray, London.

Daudin, D. and J. Sierra. 2008. Spatial and temporal variation of below-ground N transfer from a leguminous tree to an associated grass in an agroforestry system. Agriculture, Ecosystems \& Environment 126:275-280.

Del Pilar Clavijo, M., M. Nordenstahl, P. E. Gundel, and E. G. Jobbágy. 2005. Poplar afforestation effects on grassland structure and composition in the Flooding Pampas. Rangeland Ecology \& Management 58:474-479.

Deregibus, V. A. 2000. Argentina's humid grazing lands. Pages 395-405 in G. Lemaire, J. Hodgson, A. d. Moraes, C. Nabinger, and P. C. d. F. Carvalho, editors. Grassland Ecophysiology and Grazing Ecology. CABI, Wallinford, UK. 
Di Bella, C. M., E. G. Jobbágy, J. M. Paruelo, and S. Pinnock. 2006. Continental fire density patterns in South America. Global Ecology and Biogeography 15:192-199.

Di Gregorio, A. and L. J. Jansen. 2000. Land Cover Classification System (LCCS): classification concepts and user manual for software version 1.0. Food and Agriculture Organization of the United Nations Publishing Service, Rome.

DiMiceli, C. M., M. L. Carroll, R. A. Sohlberg, M. C. Hansen, and J. R. G. Townshend. 2011. Annual Global Automated MODIS Vegetation Continuous Fields (MOD44B) at $250 \mathrm{~m}$ Spatial Resolution for Data Years Beginning Day 65, 2000 - 2010. University of Maryland, College Park.

Dohn, J., F. Dembélé, M. Karembé, A. Moustakas, K. A. Amévor, and N. P. Hanan. 2013. Tree effects on grass growth in savannas: competition, facilitation and the stress-gradient hypothesis. Journal of Ecology 101:202-209.

Doughty, C. E., S. Faurby, and J.-C. Svenning. 2016. The impact of the megafauna extinctions on savanna woody cover in South America. Ecography 39:213-222.

Duran, A. 1987. La Cartografía de Suelos CONEAT y sus Posibilidades de Utilización. Facultad de Agronomía, Universidad de la República, Montevideo.

Eldridge, D. J., M. A. Bowker, F. T. Maestre, E. Roger, J. F. Reynolds, and W. G. Whitford. 2011. Impacts of shrub encroachment on ecosystem structure and functioning: towards a global synthesis. Ecology Letters 14:709-722.

Etchebarne, V. and A. Brazeiro. 2016. Effects of livestock exclusion in forests of Uruguay: soil condition and tree regeneration. Forest Ecology and Management 362:120-129.

FAO-ISRIC. 2010. Harmonized World Soil Database (version 1.1). FAO and IIASA Rome and Laxenburg.

FAO. 1999. Tropical Livestock Units (TLU). Livestock \& Environment Toolbox. FAO, Rome. 
Fearnside, P. M. 1990. Fire in the tropical rainforest of the Amazon basin. Pages 106-116 in J. G. Goldammer, editor. Fire in the Tropical Biota. Springer, Berlin.

February, E. C., S. I. Higgins, W. J. Bond, and L. Swemmer. 2013. Influence of competition and rainfall manipulation on the growth responses of savanna trees and grasses. Ecology 94:1155-1164.

Fernández, G., M. Texeira, and A. Altesor. 2014. The small scale spatial pattern of C3 and C4 grasses depends on shrub distribution. Austral Ecology 39:532-539.

Foley, J. A., R. DeFries, G. P. Asner, C. Barford, G. Bonan, S. R. Carpenter, F. S. Chapin, M. T. Coe, G. C. Daily, H. K. Gibbs, J. H. Helkowski, T. Holloway, E. A. Howard, C. J. Kucharik, C. Monfreda, J. A. Patz, I. C. Prentice, N. Ramankutty, and P. K. Snyder. 2005. Global consequences of land use. Science 309:570-574.

Gallego, F. 2008. Mapping the Grassland Community of the Central-South Region (Cristalino). Thesis in Spanish. Universidad de la República, Montevideo.

Gardner, F. P., R. B. Pearce, and R. L. Mitchell. 2003. Physiology of Crop Plants. Iowa State University Press, Iowa.

Gargaglione, V., P. L. Peri, and G. Rubio. 2014. Tree-grass interactions for N in Nothofagus antarctica silvopastoral systems: evidence of facilitation from trees to underneath grasses. Agroforestry Systems 88:779-790.

Gartzia, M., C. L. Alados, and F. Pérez-Cabello. 2014. Assessment of the effects of biophysical and anthropogenic factors on woody plant encroachment in dense and sparse mountain grasslands based on remote sensing data. Progress in Physical Geography 38:201-217.

Gautreau, P. 2010. Rethinking the dynamics of woody vegetation in Uruguayan campos, 18002000. Journal of Historical Geography 36:194-204. 
Gea-Izquierdo, G., G. Montero, and I. Cañellas. 2009. Changes in limiting resources determine spatio-temporal variability in tree-grass interactions. Agroforestry Systems 76:375387.

Gibson, D. J. 2009. Grasses and Grassland Ecology. Oxford University Press.

Giglio, L., J. T. Randerson, and G. R. van der Werf. 2013. Analysis of daily, monthly, and annual burned area using the fourth-generation global fire emissions database (GFED4). Journal of Geophysical Research: Biogeosciences 118:317-328.

Gómez-Aparicio, L., R. Zamora, J. Castro, and J. A. Hódar. 2008. Facilitation of tree saplings by nurse plants: microhabitat amelioration or protection against herbivores? Journal of Vegetation Science 19:161-172.

Griscom, H. P., P. M. S. Ashton, and G. P. Berlyn. 2005. Seedling survival and growth of native tree species in pastures: implications for dry tropical forest rehabilitation in central Panama. Forest Ecology and Management 218:306-318.

Hansen, M. C., R. S. DeFries, J. R. G. Townshend, M. Carroll, C. Dimiceli, and R. A. Sohlberg. 2003. Global percent tree cover at a spatial resolution of 500 meters: first results of the MODIS Vegetation Continuous Fields algorithm. Earth Interactions 7:1-15.

Hansen, M. C., J. R. Townshend, R. S. DeFries, and M. Carroll. 2005. Estimation of tree cover using MODIS data at global, continental and regional/local scales. International Journal of Remote Sensing 26:4359-4380.

Haretche, F., P. Mai, and A. Brazeiro. 2012. Woody flora of Uruguay: inventory and implication within the Pampean region. Acta Botanica Brasilica 26:537-552.

Haylock, M., T. Peterson, L. Alves, T. Ambrizzi, Y. Anunciação, J. Baez, V. Barros, M. Berlato, M. Bidegain, and G. Coronel. 2006. Trends in total and extreme South American rainfall in 1960-2000 and links with sea surface temperature. Journal of Climate 19:1490-1512. 
Hempson, G. P., S. Archibald, and W. J. Bond. 2015a. A continent-wide assessment of the form and intensity of large mammal herbivory in Africa. Science 350:1056-1061.

Hempson, G. P., S. Archibald, W. J. Bond, R. P. Ellis, C. C. Grant, F. J. Kruger, L. M. Kruger, C. Moxley, N. Owen-Smith, M. J. S. Peel, I. P. J. Smit, and K. J. Vickers. 2015 b. Ecology of grazing lawns in Africa. Biological Reviews 90:979-994.

Hijmans, R. J., S. E. Cameron, J. L. Parra, P. G. Jones, and A. Jarvis. 2005. Very high resolution interpolated climate surfaces for global land areas. International Journal of Climatology 25:1965-1978.

Hirota, M., M. Holmgren, E. H. van Nes, and M. Scheffer. 2011. Global resilience of tropical forest and savanna to critical transitions. Science 334:232-235.

Hoffmann, W. A., E. L. Geiger, S. G. Gotsch, D. R. Rossatto, L. C. R. Silva, O. L. Lau, M. Haridasan, and A. C. Franco. 2012. Ecological thresholds at the savanna-forest boundary: how plant traits, resources and fire govern the distribution of tropical biomes. Ecology Letters 15:759-768.

Holdo, R. M., R. D. Holt, and J. M. Fryxell. 2009. Grazers, browsers, and fire influence the extent and spatial pattern of tree cover in the Serengeti. Ecological Applications 19:95109.

Holmgren, M., M. Scheffer, and M. A. Huston. 1997. The interplay of facilitation and competition in plant communities. Ecology 78:1966-1975.

Holmgren, M. 2002. Exotic herbivores as drivers of plant invasion and switch to ecosystem alternative states. Biological Invasions 4:25-33.

Holmgren, M., B. C. López, J. R. Gutiérrez, and F. A. Squeo. 2006a. Herbivory and plant growth rate determine the success of El Niño Southern Oscillation-driven tree establishment in semiarid South America. Global Change Biology 12:2263-2271. 
Holmgren, M., P. Stapp, C. R. Dickman, C. Gracia, S. Graham, J. R. Gutiérrez, C. Hice, F. Jaksic, D. A. Kelt, and M. Letnic. 2006b. Extreme climatic events shape arid and semiarid ecosystems. Frontiers in Ecology and the Environment 4:87-95.

Holmgren, M. and M. Scheffer. 2010. Strong facilitation in mild environments: the stress gradient hypothesis revisited. Journal of Ecology 98:1269-1275.

Holmgren, M., L. Gómez-Aparicio, J. L. Quero, and F. Valladares. 2012. Non-linear effects of drought under shade: reconciling physiological and ecological models in plant communities. Oecologia 169:293-305.

Holmgren, M., M. Hirota, E. H. van Nes, and M. Scheffer. 2013. Effects of interannual climate variability on tropical tree cover. Nature Climate Change 3:755-758.

Holmgren, M. and M. Scheffer. 2017. To tree or not to tree: cultural views from ancient romans to modern ecologists. Ecosystems 20:62-68.

House, J. I., S. Archer, D. D. Breshears, and R. J. Scholes. 2003. Conundrums in mixed woodyherbaceous plant systems. Journal of Biogeography 30:1763-1777.

Huntly, N. 1991. Herbivores and the dynamics of communities and ecosystems. Annual Review of Ecology and Systematics 22:477-503.

Huxley, P. 1999. Tropical Agroforestry. Blackwell Science, Cambridge.

IGBP-DIS. 2000. Global gridded surfaces of selected soil characteristics. Global Soil Data Task Group. International Geosphere-Biosphere Programme-Data and Information Services, Oak Ridge National Laboratory, Oak Ridge, Tennessee, USA, available online at: http://www.daac.ornl.gov/ from the ORNL Distributed Active Archive Center.

Iliffe, J. and R. Lott. 2008. Datums and Map Projections for Remote Sensing, GIS, and Surveying. Whittles Publishing, Caithness. 
Iriarte, J. 2006. Vegetation and climate change since 14,810 14C yr B.P. in southeastern Uruguay and implications for the rise of early formative societies. Quaternary Research 65:20-32.

Jackson, J. and A. J. Ash. 1998. Tree-grass relationships in open eucalypt woodlands of northeastern Australia: influence of trees on pasture productivity, forage quality and species distribution. Agroforestry Systems 40:159-176.

Jackson, L. E., R. B. Strauss, M. K. Firestone, and J. W. Bartolome. 1990. Influence of tree canopies on grassland productivity and nitrogen dynamics in deciduous oak savanna. Agriculture, Ecosystems \& Environment 32:89-105.

Jeske-Pieruschka, V., A. Fidelis, R. S. Bergamin, E. Vélez, and H. Behling. 2010. Araucaria forest dynamics in relation to fire frequency in southern Brazil based on fossil and modern pollen data. Review of Palaeobotany and Palynology 160:53-65.

Jones, P. and I. Harris. 2013. University of East Anglia Climatic Research Unit, CRU TS3. 21: Climatic Research Unit (CRU) Time-Series (TS) Version 3.21 of High Resolution Gridded Data of Month-by-month Variation in Climate (Jan. 1901-Dec. 2012). NCAS British Atmospheric Data Centre.

Kephart, K. D., D. R. Buxton, and E. S. Taylor. 1992. Growth of C3 and C4 perennial grasses under reduced irradiance. Crop Science 32:1033-1038.

Kottek, M., J. Grieser, C. Beck, B. Rudolf, and F. Rubel. 2006. World Map of the KöppenGeiger climate classification updated. Meteorologische Zeitschrift 15:259-263.

Kramer, H., C. A. Mücher, and G. W. Hazeu. 2011. Historical land use databases: a new layer of information for geographical research. International Journal of Humanities and Arts Computing 5:41-58. 
Lauenroth, W. K. 1979. Grassland primary production: North American grasslands in perspective. Pages 3-24 in N. R. French, editor. Perspectives in Grassland Ecology. Springer, New York.

Lefcheck, J. S. 2016. piecewiseSEM: piecewise structural equation modelling in R for ecology, evolution, and systematics. Methods in Ecology and Evolution 7:573-579.

Lehmann, C. E., S. A. Archibald, W. A. Hoffmann, and W. J. Bond. 2011. Deciphering the distribution of the savanna biome. New Phytologist 191:197-209.

Lehner, B., K. Verdin, and A. Jarvis. 2006. HydroSHEDS Technical Documentation, V 1. 0. WWF, Washington, DC. Available from: www. worldwildlife. org/hydrosheds.

Lemaire, G., R. Wilkins, and J. Hodgson. 2005. Challenges for grassland science: managing research priorities. Agriculture, Ecosystems \& Environment 108:99-108.

Leonard, S., J. Kirkpatrick, and J. Marsden-Smedley. 2010. Variation in the effects of vertebrate grazing on fire potential between grassland structural types. Journal of Applied Ecology 47:876-883.

Lepš, J. and P. Šmilauer. 2003. Multivariate Analysis of Ecological Data Using CANOCO. Cambridge University Press.

Levin, S. A. 1992. The problem of pattern and scale in ecology: the Robert H. MacArthur award lecture. Ecology 73:1943-1967.

Lezama, F., A. Altesor, R. J. León, and J. M. Paruelo. 2006. Heterogeneidad de la vegetación en pastizales naturales de la región basáltica de Uruguay. Ecologia Austral 16:167-182.

Lezama, F., S. Baeza, A. Altesor, A. Cesa, E. J. Chaneton, and J. M. Paruelo. 2014. Variation of grazing-induced vegetation changes across a large-scale productivity gradient. Journal of Vegetation Science 25:8-21.

Liu , J., T. Dietz, S. R. Carpenter, M. Alberti, C. Folke, E. Moran, A. N. Pell, P. Deadman, T. Kratz, J. Lubchenco, E. Ostrom, Z. Ouyang, W. Provencher, C. L. Redman, S. H. 
Schneider, and W. W. Taylor. 2007. Complexity of coupled human and natural systems. Science 317:1513-1516.

Los, S. O., J. A. B. Rosette, N. Kljun, P. R. J. North, L. Chasmer, J. C. Suárez, C. Hopkinson, R. A. Hill, E. van Gorsel, C. Mahoney, and J. A. J. Berni. 2012. Vegetation height and cover fraction between $60^{\circ} \mathrm{S}$ and $60^{\circ} \mathrm{N}$ from ICESat GLAS data. Geoscientific Model Development 5:413-432.

Ludwig, F., T. E. Dawson, H. de Kroon, F. Berendse, and H. H. T. Prins. 2003. Hydraulic lift in Acacia tortilis trees on an East African savanna. Oecologia 134:293-300.

Ludwig, F., H. Kroon, and H. H. T. Prins. 2008. Impacts of savanna trees on forage quality for a large African herbivore. Oecologia 155:487-496.

Macias, D., N. Mazía, and E. Jacobo. 2014. Grazing and neighborhood interactions limit woody encroachment in wet subtropical savannas. Basic and Applied Ecology 15:661-668.

Marengo, J. A., T. Ambrizzi, R. P. Da Rocha, L. M. Alves, S. V. Cuadra, M. C. Valverde, R. R. Torres, D. C. Santos, and S. E. Ferraz. 2010. Future change of climate in South America in the late twenty-first century: intercomparison of scenarios from three regional climate models. Climate Dynamics 35:1073-1097.

Markham, C. G. 1970. Seasonality of precipitation in the United States. Annals of the Association of American Geographers 60:593-597.

Masciadri, S., E. Brugnoli, and P. Muniz. 2010. InBUy database of Invasive and Alien Species (IAS) in Uruguay: a useful tool to confront this threat to biodiversity. Biota Neotropica 10:205-213.

McGarigal, K., S. A. Cushman, and S. Stafford. 2013. Multivariate Statistics for Wildlife and Ecology Research. Springer Science \& Business Media, New York.

McLeod, A. and C. Xu. 2011. bestglm: Best Subset GLM. R package version 0.33. URL http://CRAN. R-project. org/package= bestglm. 
MEA. 2005. Millennium Ecosystem Assessment. Ecosystems and Human Well-Being: Synthesis. Island Press, Washington, DC.

MGAP. 1976. Carta de Reconocimiento de Suelos del Uruguay. Escala 1:1000000. Dirección General De Suelos. Ministerio de Ganadería, Agricultura y Pesca, Montevideo.

MGAP. 1979. Primera Carta Forestal. Dirección Forestal, Parques y Fauna. Ministerio de Agricultura y Pesca, Montevideo.

MGAP. 2012. Cartografía Forestal 2012. Dirección General Forestal. Ministerio de Ganadería, Agricultura y Pesca, Montevideo.

Mills, A. J., A. V. Milewski, M. V. Fey, A. Gröngröft, A. Petersen, and C. Sirami. 2013. Constraint on woody cover in relation to nutrient content of soils in western southern Africa. Oikos 122:136-148.

Mistry, J. 1998. Fire in the cerrado (savannas) of Brazil: an ecological review. Progress in Physical Geography 22:425-448.

Modernel, P., W. A. H. Rossing, M. Corbeels, S. Dogliotti, V. Picasso, and P. Tittonell. 2016. Land use change and ecosystem service provision in Pampas and Campos grasslands of southern South America. Environmental Research Letters 11:113002.

Moleele, N. M., S. Ringrose, W. Matheson, and C. Vanderpost. 2002. More woody plants? the status of bush encroachment in Botswana's grazing areas. Journal of Environmental Management 64:3-11.

Molfino, J. and A. Califra. 2001. Agua Disponible de las Tierras del Uruguay. Ministerio de Ganadería, Agricultura y Pesca, Montevideo, Uruguay.

Montossi, F., M. Font-i-Furnols, M. del Campo, R. San Julián, G. Brito, and C. Sañudo. 2013. Sustainable sheep production and consumer preference trends: compatibilities, contradictions, and unresolved dilemmas. Meat Science 95:772-789. 
Müller, S. C., G. E. Overbeck, C. C. Blanco, J. M. de Oliveira, and V. P. Pillar. 2012. South Brazilian forest-grassland ecotones: dynamics affected by climate, disturbance, and woody species traits. Pages 167-187 in R. W. Myster, editor. Ecotones between forest and grassland. Springer, New York.

Murphy, B. P. and D. M. Bowman. 2012. What controls the distribution of tropical forest and savanna? Ecology Letters 15:748-758.

MVOTMA-MGAP-FAO. 2008. Mapa de cobertura de suelo de Uruguay. Land Cover Classification System. . Ministerio de Ganadería, Agricultura y Pesca. Ministerio de Vivienda, Ordenamiento Territorial y Medio Ambiente. Food and Agriculture Organization, Montevideo.

Nabinger, C., A. d. Moraes, and G. Maraschin. 2000. Campos in southern Brazil. Pages 355376 in G. Lemaire, J. Hodgson, A. Moraes, P. C. d. F. Carvalho, and C. Nabinger, editors. Grassland Ecophysiology and Grazing Ecology. CABI Publishing, New York. Nagelkerke, N. J. 1991. A note on a general definition of the coefficient of determination. Biometrika 78:691-692.

Naito, A. T. and D. M. Cairns. 2011. Patterns and processes of global shrub expansion. Progress in Physical Geography 35:423-442.

Nebel, J. P., Porcile, J.F. 2006. La Contaminación del Bosque Nativo por Especies Arbóreas y Arbustivas Exóticas. MGAP, Montevideo.

Neumann, R. B. and Z. G. Cardon. 2012. The magnitude of hydraulic redistribution by plant roots: a review and synthesis of empirical and modeling studies. New Phytologist 194:337-352.

Nordenstahl, M., P. E. Gundel, M. Pilar Clavijo, and E. G. Jobbágy. 2011. Forage production in natural and afforested grasslands of the Pampas: ecological complementarity and management opportunities. Agroforestry Systems 83:201-211. 
Ode, D. J., L. L. Tieszen, and J. C. Lerman. 1980. The Seasonal Contribution of C3 and C4 Plant Species to Primary Production in a Mixed Prairie. Ecology 61:1304-1311.

Oliveira, J. M. and V. P. Pillar. 2004. Vegetation dynamics on mosaics of Campos and Araucaria forest between 1974 and 1999 in southern Brazil. Community Ecology 5:197-202.

Olson, D. M., E. Dinerstein, E. D. Wikramanayake, N. D. Burgess, G. V. Powell, E. C. Underwood, J. A. D'amico, I. Itoua, H. E. Strand, and J. C. Morrison. 2001. Terrestrial ecoregions of the world: a new map of life on Earth. Bioscience 51:933-938.

Overbeck, G. E., S. C. Müller, A. Fidelis, J. Pfadenhauer, V. P. Pillar, C. C. Blanco, I. I. Boldrini, R. Both, and E. D. Forneck. 2007. Brazil's neglected biome: the South Brazilian Campos. Perspectives in Plant Ecology, Evolution and Systematics 9:101116.

Panario, D. 1988. Geomorfología del Uruguay: propuesta de un marco estructural y un esquema de evolución del modelado del relieve uruguayo. Facultad de Humanidades y Ciencias, Universidad de la República, Montevideo.

Pandolfi, J. M., R. H. Bradbury, E. Sala, T. P. Hughes, K. A. Bjorndal, R. G. Cooke, D. McArdle, L. McClenachan, M. J. H. Newman, G. Paredes, R. R. Warner, and J. B. C. Jackson. 2003. Global trajectories of the long-term decline of coral reef ecosystems. Science 301:955-958.

Parr, C. L., C. E. R. Lehmann, W. J. Bond, W. A. Hoffmann, and A. N. Andersen. 2014. Tropical grassy biomes: misunderstood, neglected, and under threat. Trends in Ecology \& Evolution 29:205-213.

Pausas, J. G. and E. Ribeiro. 2013. The global fire-productivity relationship. Global Ecology and Biogeography 22:728-736. 
Pearcy, R. W. and J. Ehleringer. 1984. Comparative ecophysiology of C3 and C4 plants. Plant, Cell \& Environment 7:1-13.

Pearson, R. G. and T. P. Dawson. 2003. Predicting the impacts of climate change on the distribution of species: are bioclimate envelope models useful? Global Ecology and Biogeography 12:361-371.

Peel, M. C., B. L. Finlayson, and T. A. McMahon. 2007. Updated world map of the KöppenGeiger climate classification. Hydrology and Earth System Sciences 11:1633-1644.

Pérez-Harguindeguy, N., S. Díaz, E. Garnier, S. Lavorel, H. Poorter, P. Jaureguiberry, M. S. Bret-Harte, W. K. Cornwell, J. M. Craine, D. E. Gurvich, C. Urcelay, E. J. Veneklaas, P. B. Reich, L. Poorter, I. J. Wright, P. Ray, L. Enrico, J. G. Pausas, A. C. de Vos, N. Buchmann, G. Funes, F. Quétier, J. G. Hodgson, K. Thompson, H. D. Morgan, H. ter Steege, L. Sack, B. Blonder, P. Poschlod, M. V. Vaieretti, G. Conti, A. C. Staver, S. Aquino, and J. H. C. Cornelissen. 2013. New handbook for standardised measurement of plant functional traits worldwide. Australian Journal of Botany 61:167-234.

Peri, P. L., F. Dube, and A. Varella. 2016. Silvopastoral Systems in Southern South America. Springer, New York.

Peterson, D. W., P. B. Reich, K. J. Wrage, and J. Franklin. 2007. Plant functional group responses to fire frequency and tree canopy cover gradients in oak savannas and woodlands. Journal of Vegetation Science 18:3-12.

Pillar, V. P. and F. Quadros. 1997. Grassland-forest boundaries in southern Brazil. Coenoses 12:119-126.

Piñeiro-Guerra, J. M., C. Fagúndez-Pachón, M. Oesterheld, and M. Arim. 2014. Biodiversityproductivity relationship in ponds: community and metacommunity patterns along time and environmental gradients. Austral Ecology 39:808-818. 
Piovano, E. L., D. Ariztegui, F. Córdoba, M. Cioccale, and F. Sylvestre. 2009. Hydrological variability in South America below the Tropic of Capricorn (Pampas and Patagonia, Argentina) during the last 13.0 Ka. Pages 323-351 in F. Vimeux, F. Sylvestre, and M. Khodri, editors. Past Climate Variability in South America and Surrounding Regions. Springer, New York.

Prins, H. T. and H. P. van der Jeugd. 1993. Herbivore population crashes and woodland structure in East Africa. Journal of Ecology 81:305-314.

Puerto, L. d., R. Bracco, H. Inda, O. Gutiérrez, D. Panario, and F. García-Rodríguez. 2013. Assessing links between late Holocene climate change and paleolimnological development of Peña Lagoon using opal phytoliths, physical, and geochemical proxies. Quaternary International 287:89-100.

Quesada, C. A., O. L. Phillips, M. Schwarz, C. I. Czimczik, T. R. Baker, S. Patiño, N. M. Fyllas, M. G. Hodnett, R. Herrera, S. Almeida, E. Alvarez Dávila, A. Arneth, L. Arroyo, K. J. Chao, N. Dezzeo, T. Erwin, A. di Fiore, N. Higuchi, E. Honorio Coronado, E. M. Jimenez, T. Killeen, A. T. Lezama, G. Lloyd, G. López-González, F. J. Luizão, Y. Malhi, A. Monteagudo, D. A. Neill, P. Núñez Vargas, R. Paiva, J. Peacock, M. C. Peñuela, A. Peña Cruz, N. Pitman, N. Priante Filho, A. Prieto, H. Ramírez, A. Rudas, R. Salomão, A. J. B. Santos, J. Schmerler, N. Silva, M. Silveira, R. Vásquez, I. Vieira, J. Terborgh, and J. Lloyd. 2012. Basin-wide variations in Amazon forest structure and function are mediated by both soils and climate. Biogeosciences 9:2203-2246.

Ratajczak, Z., J. B. Nippert, and S. L. Collins. 2012. Woody encroachment decreases diversity across North American grasslands and savannas. Ecology 93:697-703.

Ratnam, J., W. J. Bond, R. J. Fensham, W. A. Hoffmann, S. Archibald, C. E. R. Lehmann, M. T. Anderson, S. I. Higgins, and M. Sankaran. 2011. When is a 'forest' a savanna, and why does it matter? Global Ecology and Biogeography 20:653-660. 
Rivest, D., A. Paquette, G. Moreno, and C. Messier. 2013. A meta-analysis reveals mostly neutral influence of scattered trees on pasture yield along with some contrasted effects depending on functional groups and rainfall conditions. Agriculture, Ecosystems \& Environment 165:74-79.

Robinson, T. P., G. W. Wint, G. Conchedda, T. P. Van Boeckel, V. Ercoli, E. Palamara, G. Cinardi, L. D'Aietti, S. I. Hay, and M. Gilbert. 2014. Mapping the global distribution of livestock. PloS ONE 9:e96084.

Rodriguez-Pontes, M., F. G. Costa, F. Pérez-Miles, and C. A. Toscano-Gadea. 2016. The preHispanic landscape of the Cerro de Montevideo (Uruguay) in the sixteenth century: first eco-historical study based on biogeography of vegetation and arachnids, historiography and other evidence. Landscape Research 41:294-313.

Rodríguez, C., E. Leoni, F. Lezama, and A. Altesor. 2003. Temporal trends in species composition and plant traits in natural grasslands of Uruguay. Journal of Vegetation Science 14:433-440.

Roques, K., T. O'connor, and A. Watkinson. 2001. Dynamics of shrub encroachment in an African savanna: relative influences of fire, herbivory, rainfall and density dependence. Journal of Applied Ecology 38:268-280.

Roy, D. P., L. Boschetti, C. O. Justice, and J. Ju. 2008. The collection 5 MODIS burned area product - Global evaluation by comparison with the MODIS active fire product. Remote Sensing of Environment 112:3690-3707.

Sala, O. E. 2001. Temperate grasslands. Pages 121-137 in F. S. Chapin (III), O. E. Sala, and E. Huber-Sanwald, editors. Global Biodiversity in a Changing Environment: Scenarios for the 21st Century. Springer, New York. 
Sankaran, M., N. P. Hanan, R. J. Scholes, J. Ratnam, D. J. Augustine, B. S. Cade, J. Gignoux, S. I. Higgins, X. Le Roux, and F. Ludwig. 2005. Determinants of woody cover in African savannas. Nature 438:846-849.

Sankaran, M., J. Ratnam, and N. Hanan. 2008. Woody cover in African savannas: the role of resources, fire and herbivory. Global Ecology and Biogeography 17:236-245.

Saravia, A., D. César, E. Montes, V. Taranto, and M. Pereira. 2011. Manejo del Rodeo de Cría Sobre Campo Natural. Plan Agropecuario. MGAP - IDB, Montevideo.

Scheffer, M., S. Carpenter, J. A. Foley, C. Folke, and B. Walker. 2001. Catastrophic shifts in ecosystems. Nature 413:591-596.

Scheffer, M., E. H. Nes, M. Holmgren, and T. Hughes. 2008. Pulse-driven loss of top-down control: the critical-rate hypothesis. Ecosystems 11:226-237.

Scheffer, M. 2009. Critical Transitions in Nature and Society. Princeton University Press, Princeton.

Scheffer, M., J. Bascompte, W. A. Brock, V. Brovkin, S. R. Carpenter, V. Dakos, H. Held, E. H. van Nes, M. Rietkerk, and G. Sugihara. 2009. Early-warning signals for critical transitions. Nature 461:53-59.

Scheffer, M., R. Vergnon, J. H. C. Cornelissen, S. Hantson, M. Holmgren, E. H. van Nes, and C. Xu. 2014. Why trees and shrubs but rarely trubs? Trends in Ecology \& Evolution 29:433-434.

Scheffer, M., S. Barrett, S. R. Carpenter, C. Folke, A. J. Green, M. Holmgren, T. P. Hughes, S. Kosten, I. A. van de Leemput, D. C. Nepstad, E. H. van Nes, E. T. H. M. Peeters, and B. Walker. 2015. Creating a safe operating space for iconic ecosystems. Science 347:1317-1319.

Scholes, R. J. and S. R. Archer. 1997. Tree-grass interactions in savannas. Annual Review of Ecology and Systematics 28:517-544. 
Sexton, J. O., X.-P. Song, M. Feng, P. Noojipady, A. Anand, C. Huang, D.-H. Kim, K. M. Collins, S. Channan, C. DiMiceli, and J. R. Townshend. 2013. Global, 30-m resolution continuous fields of tree cover: Landsat-based rescaling of MODIS vegetation continuous fields with lidar-based estimates of error. International Journal of Digital Earth 6:427-448.

Sharrow, S. H., L. Buck, and J. Lassoie. 1999. Silvopastoralism: competition and facilitation between trees, livestock, and improved grass-clover pastures on temperate rainfed lands. Pages 111-130 in L. E. Buck, J.P. Lassoie, and E.C.M. Fernandes, editors. Agroforestry in Sustainable Agricultural Systems. Lewis Publisher, Boca Ratón.

Sibly, R., J., H. Brown, and A. Kodric-Brown, editors. 2012. Metabolic Ecology: A Scaling Approach, Oxford.

Soriano, A. 1992. Río de la Plata grasslands. Pages 367-407 in R. T. Coupland, editor. Ecosystems of the World. Elsevier, Amsterdam.

Staal, A. and B. M. Flores. 2015. Sharp ecotones spark sharp ideas: comment on "Structural, physiognomic and above-ground biomass variation in savanna-forest transition zones on three continents - how different are co-occurring savanna and forest formations?" by Veenendaal et al. (2015). Biogeosciences 12:5563-5566.

Staal, A., S. C. Dekker, C. Xu, and E. H. van Nes. 2016. Bistability, spatial interaction, and the distribution of tropical forests and savannas. Ecosystems 19:1080-1091.

Stacey, G., R. H. Burris, and H. J. Evans. 1992. Biological Nitrogen Fixation. Chapman \& Hall, New York.

Staver, A. C., W. J. Bond, W. D. Stock, S. J. van Rensburg, and M. S. Waldram. 2009. Browsing and fire interact to suppress tree density in an African savanna. Ecological Applications 19:1909-1919. 
Staver, A. C., S. Archibald, and S. A. Levin. 2011. The global extent and determinants of savanna and forest as alternative biome states. Science 334:230-232.

Staver, A. C. and W. J. Bond. 2014. Is there a 'browse trap'? Dynamics of herbivore impacts on trees and grasses in an African savanna. Journal of Ecology 102:595-602.

Staver, A. C. and M. C. Hansen. 2015. Analysis of stable states in global savannas: is the CART pulling the horse? - a comment. Global Ecology and Biogeography 24:1466-8238.

Steffen, W., P. J. Crutzen, and J. R. McNeill. 2007. The Anthropocene: are humans now overwhelming the great forces of nature. AMBIO: A Journal of the Human Environment 36:614-621.

Stevens, G. C. 1992. The elevational gradient in altitudinal range: an extension of Rapoport's latitudinal rule to altitude. American Naturalist 140:893-911.

Stevens, N., C. E. R. Lehmann, B. P. Murphy, and G. Durigan. 2017. Savanna woody encroachment is widespread across three continents. Global Change Biology 23:235244.

Stocker, T., D. Qin, G. Plattner, M. Tignor, S. Allen, J. Boschung, A. Nauels, Y. Xia, B. Bex, and B. Midgley. 2013. IPCC, 2013. Climate Change 2013: the Physical Science Basis. Cambridge University Press, Cambridge.

Suttie, J. M., S. G. Reynolds, and C. Batello. 2005. Grasslands of the World. FAO, Rome.

Ter Braak, C. J. F. and P. Smilauer. 2012. CANOCO reference manual and user's guide : software for ordination (version 5.0). Biometris, Wageningen.

Thornton, P. K. and M. Herrero. 2010. Potential for reduced methane and carbon dioxide emissions from livestock and pasture management in the tropics. Proceedings of the National Academy of Sciences 107:19667-19672. 
Townshend, J., M. Hansen, M. Caroll, C. DiMiceli, R. Sohlberg, and C. Huang. 2011. User Guide For The MODIS Vegetation Continuous Fields Product. Collection 5, Version 1. University of Maryland, College Park.

Treydte, A. C., I. M. A. Heitkönig, H. H. T. Prins, and F. Ludwig. 2007. Trees improve grass quality for herbivores in African savannas. Perspectives in Plant Ecology, Evolution and Systematics 8:197-205.

Treydte, A. C., C. C. Grant, and F. Jeltsch. 2009. Tree size and herbivory determine belowcanopy grass quality and species composition in savannahs. Biodiversity and Conservation 18:3989-4002.

Turner, M. G., S. E. Gergel, M. D. Dixon, and J. R. Miller. 2004. Distribution and abundance of trees in floodplain forests of the Wisconsin River: environmental influences at different scales. Journal of Vegetation Science 15:729-738.

Valderrama, J. C. 1981. The simultaneous analysis of total nitrogen and total phosphorus in natural waters. Marine Chemistry 10:109-122.

Van Auken, O. 2009. Causes and consequences of woody plant encroachment into western North American grasslands. Journal of Environmental Management 90:2931-2942.

Van der Maarel, E. 1979. Transformation of cover-abundance values in phytosociology and its effects on community similarity. Vegetatio 39:97-114.

Van Langevelde, F., C. A. Van De Vijver, L. Kumar, J. Van De Koppel, N. De Ridder, J. Van Andel, A. K. Skidmore, J. W. Hearne, L. Stroosnijder, and W. J. Bond. 2003. Effects of fire and herbivory on the stability of savanna ecosystems. Ecology 84:337-350.

Van Soest, P. J., J. B. Robertson, and B. A. Lewis. 1991. Methods for Dietary Fiber, Neutral Detergent Fiber, and Nonstarch Polysaccharides in Relation to Animal Nutrition. Journal of Dairy Science 74:3583-3597.

Van Soest, P. J. 1994. Nutritional Ecology of the Ruminant. Cornell University Press, Ithaca. 
Veldman, J. W., E. Buisson, G. Durigan, G. W. Fernandes, S. Le Stradic, G. Mahy, D. Negreiros, G. E. Overbeck, R. G. Veldman, N. P. Zaloumis, F. E. Putz, and W. J. Bond. 2015. Toward an old-growth concept for grasslands, savannas, and woodlands. Frontiers in Ecology and the Environment 13:154-162.

Von Humboldt, A. and A. Bonpland. 1807. Essay on the Geography of Plants. (2009) University of Chicago Press, Chicago.

Walter, H. 1971. Ecology of Tropical and Subtropical Vegetation. Oliver and Boyd, Edinburgh. Walther, G. 2010. Community and ecosystem responses to recent climate change. Philosophical Transactions of the Royal Society B: Biological Sciences 365:20192024.

Weltzin, J. F. and M. B. Coughenour. 1990. Savanna tree influence on understory vegetation and soil nutrients in Northwestern Kenya. Journal of Vegetation Science 1:325-332.

Whittaker, R. H. 1970. Communities and Ecosystems. Macmillan Publishing Co., London.

Wint, W. and T. P. Robinson. 2007. Gridded Livestock of the World. Food and Agriculture Organization of the United Nations, Rome.

Woodward, F., M. Lomas, and C. Kelly. 2004. Global climate and the distribution of plant biomes. Philosophical Transactions of the Royal Society of London. Series B: Biological Sciences 359:1465-1476.

Xu, C., S. Hantson, M. Holmgren, E. H. van Nes, A. Staal, and M. Scheffer. 2016. Remotely sensed canopy height reveals three pantropical ecosystem states. Ecology 97:25182521.

Zuur, A., E. N. Ieno, N. Walker, A. A. Saveliev, and G. M. Smith. 2009. Mixed Effects Models and Extensions in Ecology with R. Springer, New York. 


\section{Summary}

Plant associations are determined by complex interactions with their environment depending on resource availability, landscape features, and periodic disturbances that shape the structure and functions of these communities. Forests, savannas and grasslands extend across the global land surface, contribute to planetary processes and provide ecosystems services sustaining local production. However, the factors that explain the distribution of trees and determine these biomes are still not well understood. In this thesis, long-standing questions about the origins and distribution of these ecosystems are discussed in light of new evidence suggesting that a feedback of fire and grasses may maintain forests, savannas and grasslands as alternative tree cover states. I also address how anthropogenic land use, including the introduction of livestock, may be affecting these dynamics, particularly in the neotropics, with consequences in terms of potential transitions in tree cover regimes.

I analyze the distribution of trees in the grasslands of subtropical South America, looking at what may determine current tree cover and change dynamics (Chapters $2 \& 3$ ). The results suggest that, in non-cultivated areas, the expansion of trees into grasslands is likely limited by fire, livestock and precipitation, and that livestock likely reduces fire frequency (Chapter 2). The analyses also suggest that in the Uruguayan Campos of southeastern South America, where fire frequency is low and livestock densities are high, a release in livestock density may cause a moderate expansion of forests into grasslands (Chapter 3). To understand the consequences of a potential transition to higher tree cover by increasing precipitation, I looked at the effects of tree cover in subtropical rangelands (Chapter 5). The results indicated that isolated trees can improve the forage quality and abundance of these rangelands, with potential benefits in terms of biodiversity and ecosystem services. Lastly, I analyzed correlational patterns relating livestock density to vegetation structure across the global tropics and subtropics (Chapter 4), in an attempt to generalize the findings of Chapter 2. The results 
indicate that extensive livestock systems reduce fire frequency and impact vegetation structure, maintaining savannas and grasslands with low tree cover, low fire frequency and a higher presence of shrubs and dwarf trees.

\section{Resumen}

Las asociaciones entre plantas están determinadas por interacciones complejas con el ambiente que dependen de la disponibilidad de recursos, las características del terreno, y perturbaciones periódicas que dan forma a la estructura y función de las comunidades. Los bosques, sabanas y pastizales que se extienden a lo largo de la superficie terrestre contribuyen a los procesos planetarios y proveen servicios ecosistémicos que sostienen la producción local. Sin embargo, los factores que explican la distribución de árboles y determinan estos sistemas no son plenamente conocidos. En esta tesis, preguntas históricas sobre el origen y la distribución de estos ecosistemas son abordadas a la luz de nueva evidencia que sugiere que una retroalimentación entre la ocurrencia de incendios y el crecimiento del tapiz herbáceo mantiene bosques, sabanas y pastizales como estados alternativos. Asimismo, los usos del suelo, incluyendo la introducción del ganado, pueden afectar estas dinámicas, particularmente en los neotrópicos, alterando las dinámicas de transiciones entre estos estados.

En este trabajo analizo la distribución de árboles en los pastizales de Sudamérica subtropical y las variables que pueden determinar la distribución actual de bosques y sus dinámicas de cambios (Capítulos 2 y 3). Los resultados sugieren que, en áreas no cultivadas, la expansión de árboles está posiblemente limitada por dinámicas de fuego, la ganadería y la precipitación, y que la ganadería reduce la frecuencia de incendios. (Capítulo 2). Los análisis también sugieren que en los Campos de Uruguay, donde la frecuencia de incendios es baja y la densidad ganadera alta, un descenso en la intensidad de pastoreo puede causar una expansión moderada de bosques (Capítulo 3). Para entender las consecuencias de una transición potencial 
hacia mayores coberturas arbóreas debido al aumento de precipitación, se analizaron los efectos de la cobertura arbórea sobre el pastizal subtropical bajo manejo ganadero (Capítulo 4). Los resultados mostraron que los árboles aislados pueden mejorar la calidad y abundancia de forraje, con beneficios potenciales en términos de biodiversidad y servicios ecosistémicos. Finalmente, se analizó la relación entre densidades ganaderas y la estructura de la vegetación en los trópicos y subtrópicos globales (Capítulo 5), generalizando los hallazgos del capítulo 2. Los resultados indican que los sistemas ganaderos reducen la frecuencia de incendios y afectan la estructura de la vegetación, manteniendo sabanas y pastizales con baja cobertura arbórea, baja frecuencia de fuego y mayor presencia de arbustos y árboles de baja estatura. 


\section{Acknowledgments}

Going through a $\mathrm{PhD}$ is a journey. Like most journeys, you know where you think you are going but often don't know precisely where you are; mostly you learn as you go, and you better be ready for surprises. Having guidance and support is necessary to understand signs and indications, to keep on the right track and avoid wandering through the fields of knowledge. Many people provided guidance and support during this trip, with enduring patience and persistence.

To my love and partner Mariana, who, with generous understanding, supported me 24/7, helped me think-through my $\mathrm{PhD}$ and brought the joy of our lives, Pedrito, to play around his father's desk. To Ricardo and Beatriz, my parents, who have let me follow my dreams around the world and always been there for me. To my sisters Lucía and Cecilia and their families, for keeping us all always united. To Mario, because he is still here teaching us to believe in what we do and to move ahead, and never despair, no matter what.

To my friends from childhood and the many friends that I have had the honor to make during the years. An incomplete list includes Adri, Héctor, Gira, César, Ale, Rafa, Fefo, Rodri, Oscar, Ian, Marti, Ceci, Juan, Nico y Nati, Fofo, Gonza, Santi, Remi and Gaby and so many other good friends. To the friends and colleagues at CURE, Uruguay. To the friends in Wageningen, the Brazilian crew for the music, André y Cata, Alexandre, Reineke, Livia and all the others, to Padraic for the long talks. To Paola for her generosity towards a newcomer. To the welcoming community of Wageningen and to Kilian for being such a good landlord. To the teams at WUR from AEW and REG for being so welcoming and providing a great work environment. To Marlies, Babak, Noel, Jacqueline, Ingrid, Egbert. Many thanks to Nancy for all the help and support.

Many people helped with the field work. Thanks to Pedro Maldini, for research help and outstanding field work. To Nestor Mazzeo and CURE for the facilitation and support. To 
Inger de Jonge, who bravely produced high-quality science despite the tough conditions in the field. To Marion Buddeberg, for her hard work on old and new maps and her attention to detail. To Iván, Rocío, Jasper, Bart, Alice, Edwin, Morten and students coming to Uruguay from Wageningen bringing valuable training and knowledge.

To Claudia Fosalba for the hard work at the lab, also to Marcelo Loureiro and the people at the Lab of the Departamento de Ecología y Evolución de Facultad de Ciencias. To the Laboratorio de Suelos de Facultad de Agronomía. To Andrés Rossado, Federico Haretche. Mauro Berasategui, Paula Levrini, Verónica Etchebarne, Verónica Pinelli for help with field work, to Lucía Barthesagui for maps and SIG data.

Thanks to Felipe Lezama, Valentín Picasso, André Junqueira, Néstor Mazzeo, Gervasio Piñeiro, Walter Baethgen and César Fagúndez for valuable theoretical, practical and methodological discussions and ideas.

To a fantastic team: Arie and Bernardo, $\mathrm{PhD}$ brothers and good friends that made this scientific experience so enjoyable. Thanks to $\mathrm{Xu}$ for the friendship and generosity with his knowledge and time.

To Matías, my co-supervisor and academic support in Uruguay, always finding pathways when things got swampy and for generously sharing his deep understanding of ecological theory.

To Marten, my promotor who can connect the dots and bring sense and audacity to ideas and draw the map of knowledge to move forward. Thanks for opening a door to an awesome group of people and a vibrant exchange of ideas, science, and creation.

To Milena, for her unfaltering resolution to move forward, for guiding the day-to-day work with an outstanding understanding of how nature works and how important is to build science in the field, drawing knowledge from nature's works. An exceptional ecologist, thanks for the hard work that has made me grow as a scientist. 
Thanks the institutions and their people that made this possible: ANII, colleagues at UNDP and Fac. de Arquitectura, UdelaR, MVOTMA and MGAP.

To the workers and landowners of Durazno, many thanks. Gracias a capataces y propietarios de Durazno: Méndez, Rojas, Rosas, Gelós, De la Torre, De León, y otros propietarios que en forma desprendida y sin pretender nada a cambio ayudaron, asistieron, abrieron porteras y movieron caballos y tractores para llevar la tesis adelante. A la comunidad de Durazno por el apoyo y la buena disposición con nuestro trabajo. 


\section{Short biography}

Rafael Bernardi was born in Montevideo, Uruguay in 1974. He has enjoyed nature and books since being capable to experience and read. He has a degree in Environmental Hydraulics Engineering at Universidad de la República (UdelaR), Uruguay, and a specialization in Development Studies at the Graduate Institute in Geneva, Switzerland. He did a Master of Environmental Management at Yale University, USA, as an OAS-Fulbright Scholar. He has working experience on environmental management in the NGO and government sector, and in international organizations including ten years with UNDP. He is now an Adjunct Professor at the Centro Universitario Regional del Este (CURE), UdelaR and an Advisor to the National Director of Environment of Uruguay. This PhD seeks to integrate ecology into the question of how the community of life creates - or not- the conditions for its well-being in a drastically changing planet, and to draw on the knowledge and inspiration of a truly exceptional team at Wageningen University and at UdelaR, Uruguay. 


\section{Publications}

Bernardi, R.E., I.K. de Jonge, and M. Holmgren. 2016. Trees improve forage quality and abundance in South American subtropical grasslands. Agriculture, Ecosystems \& Environment, 232, 227-231.

Bernardi, R.E., M. Holmgren, M. Arim, and M. Scheffer. 2016. Why are forests so scarce in subtropical South America? The shaping roles of climate, fire and livestock. Forest Ecology and Management, 363:212 - 217.

Bernardi, R.E., M. Holmgren, A. Staal, C. Xu, and M. Scheffer. Livestock suppresses fire across the global tropics. Submitted.

Bernardi, R.E., M. Buddeberg, M. Arím, and M, Holmgren. Land use drives forest-grasslands transitions in subtropical South America. Submitted.

\section{Other relevant publications}

Bernardi, R.E. Road development in Podocarpus National Park, Ecuador: an assessment of threats and opportunities. 2007. Journal of Sustainable Forestry, 28(6):735 - 754.

Clark, S.; D. Cherney, I. Angulo, R.E. Bernardi, and C. Moran-Cahusac. 2007. Problemoriented overview of management policy for Podocarpus National Park, Ecuador. Journal of Sustainable Forestry, 28(6):663 - 679.

Clark, S., D. Cherney, I. Angulo, R.E. Bernardi, C. Moran-Cahusac. 2007. An Initial Social Process (Contextual) Map for Podocarpus National Park, Ecuador. Journal of Sustainable Forestry, 28(6):680 - 693.

Bernardi, R.E. Modelling from below: the social dynamics of land use change in the buffer zone of Cordillera Azul National Park, Peru. 2005. Tropical Resources, TRI, Yale University. 


\section{SENSE}

Netherlands Research School for the

Socio-Economic and Natural Sciences of the Environment

\section{I P L O M A}

For specialised PhD training

The Netherlands Research School for the Socio-Economic and Natural Sciences of the Environment (SENSE) declares that

\section{Rafael Bernardi}

born on 18 January 1974 in Montevideo, Uruguay

has successfully fulfilled all requirements of the Educational Programme of SENSE.

Wageningen, 15 November 2017

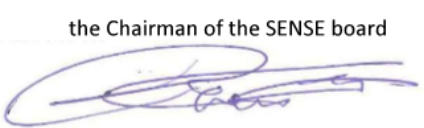

Prof. dr. Huub Rijnaarts

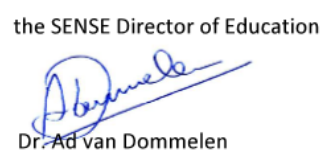

The SENSE Research School has been accredited by the Royal Netherlands Academy of Arts and Sciences (KNAW)

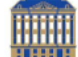

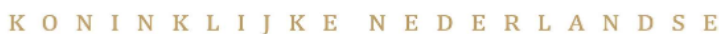

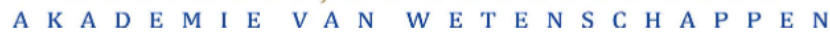




\section{SENSE}

The SENSE Research School declares that Mr Rafael Bernardi has successfully fulfilled all requirements of the Educational PhD Programme of SENSE with a work load of $37.5 \mathrm{EC}$, including the following activities:

\section{SENSE PhD Courses}

- Environmental research in context (2015)

- Research in context activity: 'Producing stakeholder communication by report and radio interview, and mainstreaming science into policy and management on the workshop "Forest - grassland transitions in Uruguay: knowledge and management" ' (2015)

o Complex dynamics in human-environment systems (2013)

\section{Other PhD and Advanced MSc Courses}

- Online course Statistical inference, John Hopkins University (2015)

Introduction to R statistical package, Universidad de la República Uruguay (2013)

\section{Management and Didactic Skills Training}

- Organization of workshop 'Tree grass changes in Uruguay: knowledge and management', the Centro Universitario de la Región Este (CURE), Universidad de la República Uruguay (2015)

- Co-ordinating and partly lecturing BSc course 'Introduction to environmental management' at CURE, Universidad de la República Uruguay (2015)

- Teaching BSc classes on Environmental policy, and Environmental philosophy and ethics at CURE, University of the Republic, Uruguay (2015)

- Supervising a BSc student with thesis entitled 'The impact of tree cover on grass and cattle productivity in tropical and subtropical ecosystems' (2015)

- Co-supervising MSc student with thesis entitled 'What drives forest-grassland transitions in subtropical South America?' (2014) and supervising field work of MSc student with thesis entitled 'Forest-grassland transitions in subtropical South America: tree recruitment patterns at the ecotone between riverine forests and grasslands' (2015)

\section{$\underline{\text { Oral Presentations }}$}

- Tree cover effects on grassland productivity in subtropical South America. Conference of the Society of Tropical Ecology, 7-10 April 2015, Zurich, Switzerland

- Drivers of grassland-forest transitions in subtropical South America: implications for landscape restoration and management. VII World Congress on Ecological Restoration, 27 August - 1 September 2017, Foz do Iguassu, Brazil

SENSE Coordinator PhD Education 
Rafael Bernardi received a PhD fellowship from the National Research and Innovation Agency (ANII) of Uruguay. Field research and laboratory analyses were funded by the Alberta Mennega Foundation (The Netherlands) and The Royal Netherlands Academy of Arts and Sciences (KNAW) and supported by the Centro Universitario Regional del Este (CURE), Universidad de la República of Uruguay (UDELAR).

Cover Design by Ruben Stoel, pictures by Rafael Bernardi Printed by: ProefschriftMaken | Proefschriftmaken.nl 